EFEITO DE EXTRATOS DE Trichilia pallida SWARTZ E Azadirachta indica A. JUSS (MELIACEAE) SOBRE Tuta absoluta (MEYRICK) E SEU PARASITÓIDE Trichogramma pretiosum RILEY

RITA DE CÁSSIA RODRIGUES GONÇALVES-GERVÁSIO

Tese apresentada à Escola Superior de Agricultura "Luiz de Queiroz", Universidade de São Paulo, para obtenção do título de Doutor em Ciências, Área de Concentração: Entomologia.

PIRACICABA

Estado de São Paulo - Brasil

Outubro - 2003 
EFEITO DE EXTRATOS DE Trichilia pallida SWARTZ E Azadirachta indica A. JUSS (MELIACEAE) SOBRE Tuta absoluta (MEYRICK) E SEU PARASITÓIDE Trichogramma pretiosum RILEY

RITA DE CÁSSIA RODRIGUES GONÇALVES-GERVÁSIO

Engenheira Agrônoma

Orientador: Prof. Dr. JOSÉ DJAIR VENDRAMIM

Tese apresentada à Escola Superior de Agricultura "Luiz de Queiroz", Universidade de São Paulo, para obtenção do título de Doutor em Ciências, Área de Concentração: Entomologia.

PIRACICABA

Estado de São Paulo - Brasil

Outubro - 2003 
Dados Internacionais de Catalogação na Publicação (CIP) DIVISÃO DE BIBLIOTECA E DOCUMENTAÇÃO - ESALQ/USP

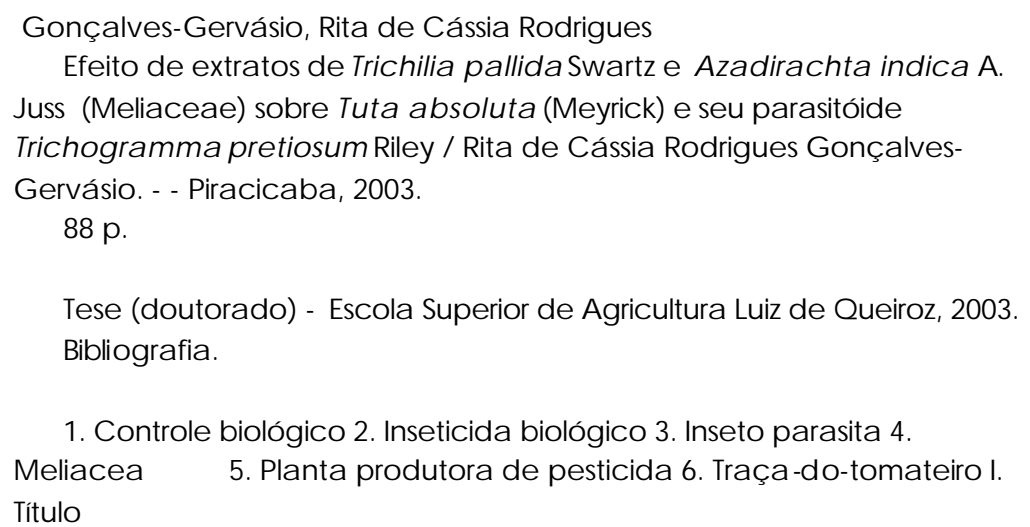

CDD 632.951 
Aos meus pais Geraldo e Izabel, que mesmo com muita dificuldade, me proporcionaram a melhor educação possível

\section{OFEREÇO}

Ao meu marido Eliezer, Pelo carinho e apoio, demonstrados em todos os momentos 


\section{AGRADECIMENTOS}

A Deus, por mais essa conquista;

À Escola Superior de Agricultura "Luiz de Queiroz", da Universidade de São Paulo (ESALQ/USP), pela oportunidade de realização do curso;

À Coordenadoria de Aperfeiçoamento de Pessoal de Nível Superior (CAPES), pela concessão da bolsa de estudo e à Fundação de Amparo à Pesquisa do Estado de São Paulo (FAPESP), pelo apoio financeiro oferecido na realização desse trabalho;

Ao Prof. Dr. José Djair Vendramim, pela orientação, apoio e exemplo de dedicação profissional;

Aos demais professores do Departamento de Entomologia, Fitopatologia e Zoologia Agrícola da ESALQ/USP, pelos ensinamentos transmitidos;

Aos amigos do Laboratório de Plantas Inseticidas, Antônio, Bruno, Cia, Edilene, Élio, Enrique, Fábio, Fernanda, Márcio, Marilene, Paulo, Rogério, Romildo, Uemerson e Vanessa, pelo convívio harmonioso durante a realização do curso;

Aos amigos do curso de Pós-Graduação em Entomologia, pelo convívio e respeito;

Aos funcionários do Setor de Entomologia, pelos auxílios prestados;

$\mathrm{E}$ a todos aqueles que, direta ou indiretamente, contribuíram para a realização deste trabalho. 


\section{SUMÁRIO}

Página

RESUMO …....................................................................... viii

SUMMARY ................................................................... $\mathrm{X}$

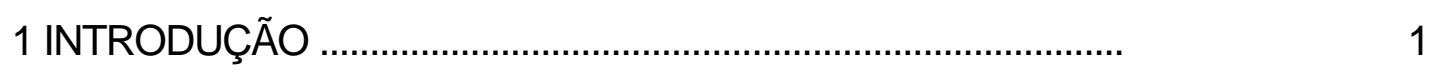

2 REVISÃO DE LITERATURA ..................................................... 4

2.1 Considerações gerais sobre Tuta absoluta ................................ 4

2.2 Inseticidas de origem vegetal com ênfase a derivados de Trichilia pallida .......................................................................

2.3 Efeito de extratos de meliáceas sobre insetos minadores ........... 9

2.4 Modo de ação dos compostos presentes em extratos de meliáceas ..............................................................................

2.5 Controle biológico da traça-do-tomateiro com parasitóides do gênero Trichogramma .............................................................

2.6 Efeito de extratos de meliáceas sobre insetos do gênero Trichogramma .................................................................... 21

3 MATERIAL E MÉTODOS .......................................................... 23

3.1 Obtenção e criação dos insetos ................................................ 23

3.2 Obtenção do material vegetal para preparo dos extratos ............ 24

3.3 Testes preliminares ............................................................... 25

3.3.1 Determinação das concentrações adequadas dos extratos a serem utilizadas nos experimentos........................................... 25

3.3.1.1 Preparo dos extratos ........................................................ 25 


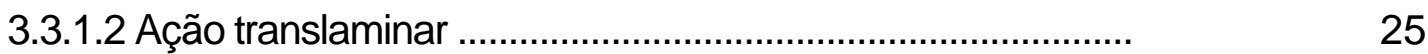

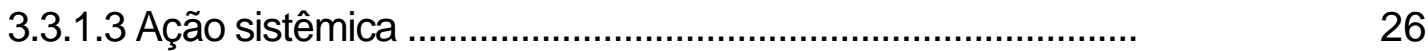

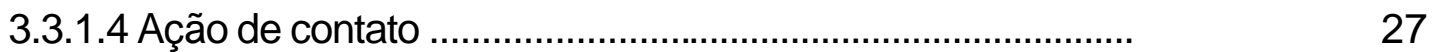

3.3.2 Avaliação da atividade de extratos orgânicos de T. pallida sobre T. absoluta

3.3.2.1 Preparo dos extratos orgânicos ............................................. 27

3.3.2.2 Testes de bioatividade ......................................................... 28

3.4 Determinação do modo de ação de extratos de folhas de $T$. pallida sobre T. absoluta

3.5 Efeito de extratos de meliáceas sobre o parasitóide $T$. pretiosum

3.5.1 Tratamento dos ovos antes do parasitismo ............................. 30

3.5.1.1 Teste com chance de escolha ............................................ 30

3.5.1.2 Teste sem chance de escolha ............................................ 31

3.5.2 Tratamento dos ovos após o parasitismo................................. 31

3.6 Análise estatística .................................................................... 32

4 RESULTADOS E DISCUSSÃO ............................................... 33

4.1 Testes preliminares .............................................................. 33

4.1.1 Determinação das concentrações adequadas dos extratos a serem utilizadas nos experimentos ...................................... 33

4.1.1.1 Ação translaminar ............................................................. 33

4.1.1.2 Ação sistêmica .................................................................. 35

4.1.1.3 Ação de contato ............................................................ 37

4.1.2 Avaliação da atividade de extratos orgânicos de T. pallida sobre T. absoluta ................................................................... 39

4.1.3 Considerações gerais .......................................................... 42

4.2 Determinação do modo de ação de extratos de folhas de $T$. pallida sobre T. absoluta....................................................... 45

4.2.1 Ação translaminar ............................................................. 45

4.2.2 Ação sistêmica ............................................................... 50 
4.2.3 Ação de contato

4.2.4 Considerações gerais

4.3 Efeito de extratos de meliáceas sobre o parasitóide $T$. pretiosum

61

4.3.1 Tratamento dos ovos antes do parasitismo 61

4.3.1.1 Teste com chance de escolha 61

4.3.1.2 Teste sem chance de escolha .... 64

4.3.2 Tratamento dos ovos após o parasitismo 66

4.3.3 Considerações gerais 70 5 CONCLUSÕES 72 REFERÊ NCIAS BIBLIOGRÁFICAS 73 


\title{
EFEITO DE EXTRATOS DE Trichilia pallida SWARTZ E Azadirachta indica A. JUSS (MELIACEAE) SOBRE Tuta absoluta (MEYRICK) E SEU PARASITÓIDE Trichogramma pretiosum RILEY
}

\author{
Autora: RITA DE CÁSSIA RODRIGUES GONÇALVES-GERVÁSIO \\ Orientador: Prof. Dr. JOSÉ DJAIR VENDRAMIM
}

\section{RESUMO}

Esse trabalho foi desenvolvido com o objetivo de verificar a bioatividade de extratos aquosos e orgânicos de folhas de Trichilia pallida e do extrato aquoso de sementes de Azadirachta indica (nim) sobre Tuta absoluta e seu parasitóide Trichogramma pretiosum. Procurou-se determinar os efeitos sistêmico, translaminar e de contato dos extratos sobre a praga, além do efeito sobre a biologia e comportamento do parasitóide. Primeiramente, foram realizados experimentos visando à determinação das concentrações dos extratos mais adequadas para utilização nos testes de bioatividade. Nesta etapa preliminar, foram utilizados apenas extratos aquosos de sementes de nim em concentrações variáveis de 0,5 a 10\%. Esses extratos foram aplicados no solo, na superfície adaxial de folíolos de tomateiro e diretamente sobre o inseto para a determinação dos efeitos sistêmico, translaminar e de contato, respectivamente, sendo selecionadas as concentrações de 0,$5 ; 1$ e $5 \%$ para os respectivos testes. Após a escolha das concentrações, foi selecionado, dentre quatro extratos orgânicos de folhas de T. pallida (hexânico, metanólico, 
etanólico e clorofórmico) o extrato clorofórmico como o mais eficiente sobre a praga. Determinadas as concentrações e o extrato orgânico de $T$. pallida mais eficiente, este, juntamente com 0 extrato aquoso dessa espécie e o de sementes de nim foram submetidos aos testes de bioatividade para verificar os efeitos sobre a traça-do-tomateiro. Finalmente os extratos que apresentaram melhores resultados sobre a praga foram avaliados em relação ao parasitóide de ovos $T$. pretiosum. De acordo com os resultados obtidos, foi possível concluir que os extratos aquosos de sementes de nim apresentam efeitos translaminar, sistêmico e por contato sobre $T$. absoluta, provocando alta mortalidade mesmo em concentrações menores do que $5 \%$. Verificou-se também, que o extrato clorofórmico é mais eficiente que o hexânico e o aquoso em relação à traça-do-tomateiro, e que extratos aquosos e clorofórmicos de folhas dessa espécie, em concentrações maiores do que $5 \%$ prejudicam o desenvolvimento de T. absoluta. Esses extratos atuam de forma translaminar, sistêmica e por contato, sendo o efeito translaminar mais pronunciado que os demais. Com relação ao parasitóide $T$. pretiosum, verificou-se que o mesmo é sensível ao extrato aquoso de sementes de nim na concentração de $10 \%$ e que os extratos aquosos e clorofórmicos de folhas de $T$. pallida na concentração de $10 \%$ não afetam o seu parasitismo e nem o seu desenvolvimento no interior do ovo hospedeiro. 


\title{
EFFECT OF EXTRACTS OF Trichilia pallidaSWARTZ AND Azadirachta indica (MELIACEAE) ON Tuta absoluta (MEYRICK) AND ITS PARASITOID Trichogramma pretiosum RILEY
}

\author{
Author: RITA DE CÁSSIA RODRIGUES GONÇALVES-GERVÁSIO \\ Adviser: Prof. Dr. JOSÉ DJAIR VENDRAMIM
}

\section{SUMMARY}

This research was developed in order to verify the bioactivity of Trichilia pallida aqueous and organic leaf extracts and Azadirachta indica (neem) aqueous seed extract on Tuta absoluta and its parasitoid Trichogramma pretiosum. Besides the parasitoid's behavior and biology, were also determined the systemic, translaminar and contact effects of the extracts on the pest. Firstly, for the utilization in bioactivity tests, experiments aiming the determination of the most appropriate extract concentrations were conducted. In this preliminar stage, only neem aqueous seed extract in variable concentrations from $0.5 \%$ to $10 \%$ were used. For the determination of systemic, translaminar and contact effects, these extract were applied in the soil, in adaxial surface of the tomato plant foliole and directly over the insect, respectively. For those respective tests 0.5; 1 and $5 \%$ concentrations were selected. Afterwards, the one with the higher activity on $T$. absoluta was selected among four organic $T$. pallida leaf extract (hexanic, methanolic, ethanolic and chloroformic). In this test, the chloroformic extract was considered the most effective on the pest. After the concentrations 
and most effective T. pallida organic extract having been determined, this organic extract along with the aqueous extract of this specie and the neem seed were submitted to bioactivity tests in order to verify the effects on the tomato pinworm. Finally, the extracts that presented the best results over the pest were evaluated in relation to the parasitoid T. pretiosum. According to the results it was possible to conclude that the aqueous extracts of neem seed present systemic, translaminar and contact effects on $T$. absoluta, causing high mortality in concentration smaller than $5 \%$. It was also observed that the chloroformic extract from T. pallida leaves is more efficient than the hexanic and aqueous ones in relation to the tomato pinworm and that chloroformic and aqueous extracts of $T$. pallida leaves in concentrations higher than $5 \%$ disrupt $T$. absoluta development. These extracts have systemic, translaminar and contact mode of action, being the translaminar effect more distinguished than the others. It was observed that $T$. pretiosum parasitoid is sensitive to the aqueous extract of neem seed in a concentration of $10 \%$, and that the chloroformic and aqueous extracts of $T$. pallida leaves in a concentration of $10 \%$ neither affect its parasitism nor its development inside the host egg. 


\section{INTRODUÇÃO}

A traça, Tuta absoluta (Meyrick, 1917), é uma praga de grande importância econômica na cultura do tomateiro. Esse lepidóptero da família Gelechiidae apresenta ampla distribuição geográfica, tendo sido encontrado nos principais países produtores da América do Sul. No Brasil, esse inseto foi constatado pela primeira vez em plantas de tomate, no estado do Paraná, em 1979 (Muszinski et al., 1982), sendo registrado no ano seguinte no estado de São Paulo (Moreira et al., 1982). Atualmente, acredita-se que essa praga se encontra disseminada por praticamente todas as regiões produtoras de tomate do país.

Os danos causados pela traça podem ser observados em toda a parte aérea da planta. As lagartas constróem galerias nas folhas, ramos e frutos, sendo que essas galerias aumentam à medida que o inseto se alimenta. Sob ataque intenso, as folhas minadas amarelecem, murcham e caem, podendo ocorrer morte da planta. Os frutos podem ser totalmente destruídos, caindo em seguida (Groppo, 1983). Scardini et al. (1983) constataram danos severos dessa praga à cultura do tomateiro no município de Santa Teresa, ES, com perdas de até $100 \%$ na produção, em alguns casos.

Apesar da eficiência questionável, o controle químico da traça-dotomateiro tem sido exaustivamente utilizado pelos agricultores. Além de causarem problemas como aumento significativo no custo de produção e aparecimento de pragas secundárias, poucos inseticidas oferecem controle satisfatório, uma vez que seu uso indiscriminado favorece o aparecimento de biótipos resistentes (Castelo Branco, 1990; França et al., 1985). 
Esses problemas podem ser minimizados com o emprego de métodos alternativos de controle, dentre os quais o uso de plantas inseticidas tem surgido como uma ferramenta importante no manejo de insetos pragas. Nesse sentido, o potencial inseticida de plantas da família Meliaceae tem sido avaliado no Laboratório de Plantas Inseticidas do Setor de Entomologia da ESALQ/USP, obtendo-se resultados promissores, principalmente com Trichilia pallida Swartz (Rodríguez \& Vendramim, 1996, 1997; Roel et al., 2000a, 2000b; Souza \& Vendramim, 2000a, 2000b, 2001; Thomazini et al., 2000; Torrecillas \& Vendramim, 2001; Vendramim \& Torrecillas, 1998).

Em relação a T. absoluta, Thomazini et al. (2000) verificaram que o tratamento de folhas de tomateiro com extratos de T. pallida afetou o desenvolvimento e a sobrevivência larval desse inseto, sendo constatada ainda maior eficiência do extrato de folhas quando comparado ao de ramos.

Considerando que num programa de manejo integrado, é sempre interessante utilizar mais de uma tática de controle, visando reduzir a pressão de seleção de cada uma sobre a população do inseto praga, alguns inimigos naturais também têm sido estudados para o controle da traça-do-tomateiro. Dentre estes, incluem-se os parasitóides da família Trichogrammatidae, destacando-se Trichogramma pretiosum Riley, 1879, considerado um dos mais importantes agentes de controle biológico dessa praga (França et al., 1993; Haji et al., 1995; Roa \& Jimenez, 1992).

Não se sabe, entretanto, quais os tipos de ação provocados no inseto e na planta pelos compostos químicos presentes em extratos de $T$. pallida que acabam resultando em efeitos deletérios sobre a traça-do-tomateiro.

Assim, considerando-se que a associação entre inimigos naturais e extratos vegetais com atividade inseticida pode se constituir numa alternativa viável para o controle de pragas, no presente trabalho procurou-se determinar o modo de ação, incluindo os efeitos de contato, sistêmico e translaminar de extratos aquosos e orgânicos de $T$. pallida sobre $T$. absoluta, bem como seu efeito sobre o parasitóide de ovos T. pretiosum. Para isso, esses extratos foram 
comparados com o extrato aquoso de sementes de nim, considerada uma das mais importantes plantas inseticidas na atualidade. 


\section{REVISÃO DE LITERATURA}

\subsection{Considerações gerais sobre Tuta absoluta}

A traça-do-tomateiro foi originalmente descrita como Phtorimaea absoluta por E. Meyrick, em 1917. Após ter sido transferida para três gêneros diferentes (Gnorimoschema, Scrobipalpula e Scrobipalpuloides), foi finalmente incluída no gênero Tuta por Povolný em 1994. Dessa forma, atualmente o nome válido para essa espécie é Tuta absoluta (Meyrick, 1917) (Povolný, 1975; Povolný, 1994).

Os adultos desse lepidóptero da família Gelechiidae são pequenas mariposas com $3 \mathrm{~mm}$ de comprimento e $11 \mathrm{~mm}$ de envergadura. Sua coloração é geralmente cinza-prateada, com numerosos pontos escuros na parte dorsal das asas anteriores. Têm os bordos das asas posteriores franjados, o mesmo ocorrendo na parte apical das anteriores. Os ovos são elípticos, apresentando inicialmente coloração amarelo-palha, passando a avermelhada, próximo à eclosão. As lagartas de primeiro ínstar caracterizam-se por apresentar coloração verde-clara, a qual se torna cada vez mais intensa àmedida que o inseto se alimenta. Ao atingirem o quarto e último ínstar, essas lagartas apresentam coloração verde-escura, com uma faixa longitudinal dorsal rósea que se torna avermelhada e bem distinta próximo à pupação. Ao final da fase laval, a traça passa pelo estágio de pupa, instalando-se nos caules e folhas por meio de pequenos casulos, ou ainda dentro da própria lesão, ou no solo, como pupa nua (Ferreira \& Anjos, 1997; Souza \& Reis, 1992). 
Esse inseto apresenta ampla distribuição geográfica, sendo encontrado nos principais países produtores de tomate da América do Sul. No Brasil, foi constatado pela primeira vez em plantas de tomate, no Estado do Paraná, em 1979 (Muszinski et al., 1982). Posteriormente, sua ocorrência também foi relatada em outros Estados como São Paulo (Moreira et al., 1982), Espírito Santo (Scardini et al., 1983), Bahia (Moraes \& Normanha Filho, 1982), Rio de Janeiro (Gonçalves et al., 1983) e Minas Gerais (Souza et al., 1983).

Os hospedeiros da traça-do-tomateiro pertencem à amília Solanaceae, destacando-se entre eles plantas de tomate (Lycopersicon esculentum), batata (Solanum tuberosum) e fumo (Nicotiana tabacum), além de Solanum saponaceum, Solanum guitoense (Povolný, 1975), S. nigrum, Lycopersicon puberulum e Datura stramonium (Vargas, 1970).

Os danos causados por essa praga podem ser observados em toda a parte aérea da planta. Segundo Groppo (1983), as lagartas constróem galerias nas folhas, ramos e frutos. Essas galerias aumentam àmedida que 0 inseto se alimenta e cresce. Sob ataque intenso, as folhas minadas amarelecem, murcham e caem, podendo ocorrer morte da planta. Os frutos podem ser totalmente destruídos, caindo em seguida. Scardini et al. (1983) constataram danos severos dessa praga à cultura do tomateiro no município de Santa Teresa, ES, com perdas de até 100\% na produção, em alguns casos.

\subsection{Inseticidas de origem vegetal com ênfase a derivados de Trichilia pallida}

O controle de pragas com produtos botânicos surgiu antes mesmo do advento dos inseticidas sintéticos. De acordo com Lagunes \& Rodríguez (1989), os primeiros fitoinseticidas utilizados foram a nicotina extraída de Nicotiana tabacum (Solanaceae), a rianodina extraída de Ryania speciosa (Flacuortiaceae), a sabadina e outros alcalóides provenientes de Schoenocaulon officinale (Liliaceae), as piretrinas extraídas de Chrysanthemum 
cinerariaefolium (Asteraceae) e a rotenona encontrada em Derris spp. e Lanchocarpus spp. (Fabaceae). Esses compostos foram substituídos pelos inseticidas organo-clorados que se mostravam mais eficientes no controle de insetos. Entretanto, a necessidade de novos compostos para uso no manejo de pragas sem problemas como a contaminação ambiental, resíduos nos alimentos, efeitos prejudiciais sobre organismos benéficos e aumento na freqüência de insetos resistentes, provocou a retomada dos estudos envolvendo extratos vegetais (Vendramim, 1997).

Neste contexto, a família Meliaceae tem se destacado por possuir espécies com alta atividade biológica sobre insetos. Dentre essas, incluem-se Azadirachta indica, conhecida como nim e Melia azedarach, comumente chamada de cinamomo, pára-raios ou santa-bárbara, sendo a primeira considerada uma das mais eficientes plantas inseticidas já estudadas (Breuer \& Devkota, 1990; Mordue (Luntz) \& Blackwell, 1993; Schmutterer, 1988).

Além das plantas mencionadas, vários pesquisadores têm isolado limonóides de diferentes espécies do gênero Trichilia e demonstrado a atividade desses compostos sobre insetos, incluindo efeito fagodeterrente e efeito regulador de crescimento (Nakanishi, 1982; Nakatani et al., 1985; Ortego et al., 1999; Ramirez et al., 2000; Simmonds et al., 2001; Xie et al., 1994).

Trabalhos desenvolvidos no Setor de Entomologia da ESALQ, com o objetivo de avaliar o efeito de extratos de Meliaceae sobre insetos, destacaram T. pallida como sendo uma espécie muito promissora no controle de pragas.

Rodríguez \& Vendramim (1996, 1997) avaliaram a bioatividade de várias espécies de meliáceas (incluindo cinco espécies de Trichilia), em relação a Spodoptera frugiperda. Os autores testaram extratos aquosos de diversas estruturas vegetais na concentração de $5 \%$, sendo os mesmos incorporados em dieta artificial (20 ml do extrato por $100 \mathrm{~g}$ de dieta). Foram constatadas grandes variações na bioatividade considerando-se as espécies e os órgãos vegetais utilizados. Foi observada maior eficiência em tratamentos correspondentes a extratos de folhas e ramos de $T$. pallida e de $M$. azedarach 
e ramos de Cabralea canjerana, nos quais foi registrada mortalidade larval de $100 \%$, sendo que nos extratos de ramos de T. pallida e C. canjerana, essa mortalidade ocorreu já nos dois primeiros ínstares.

Estudando o efeito de diferentes concentrações do extrato aquoso de ramos e folhas de $T$. pallida na sobrevivência e desenvolvimento de $S$. frugiperda criada em diferentes genótipos de milho, Vendramim \& Torrecillas (1998) verificaram que o extrato de ramos a $5 \%$ provocou $100 \%$ de mortalidade larval até o sétimo dia após o início do tratamento. A 1\%, a mortalidade, nesse extrato, variou de 70 a $100 \%$ e a $0,1 \%$, houve redução da sobrevivência e do peso pupal e alongamento da fase larval. $\mathrm{O}$ extrato de folhas a $5 \%$ provocou mortalidade variável de 17 a 55\% (dependendo do genótipo) até o sétimo dia e de $100 \%$ ao final da fase, enquanto a $0,1 \%$, reduziu o peso pupal. Quando os extratos de folhas e ramos de $T$. pallida foram associados a genótipos resistentes de milho, verificaram-se efeitos variáveis, em função do genótipo e concentração do extrato utilizado.

Roel et al. (2000a) avaliaram o efeito de diferentes concentrações de extratos orgânicos de folhas e ramos de $T$. pallida na sobrevivência larval de $S$. frugiperda. Num primeiro teste, envolvendo extratos acetônicos e metanólicos em concentrações variando de 0,008 a $1 \%$, os autores constataram maior eficiência dos extratos acetônicos de folhas e de ramos bem como do extrato metanólico de ramos. Neste trabalho, também foram testados extratos acetato de etila e hexânico obtidos pela partição do extrato acetônico bruto, constatando-se, nesse caso maior eficiência com o extrato acetato de etila.

Com base nestes resultados, Roel et al. (2000b) realizaram outro teste para avaliar o efeito do extrato acetato de etila de folhas e ramos de T. pallida sobre o desenvolvimento e sobrevivência da lagarta-do-cartucho. Verificou-se que o referido extrato causou mortalidade larval de 100\% (em concentração igual ou superior a 0,05\%), afetou a sobrevivência e o desenvolvimento do inseto (na concentração de 0,006\%) e não provocou qualquer efeito em concentração igual ou inferior a $0,0008 \%$. Nesse teste, também ficou 
demonstrado que lagartas alimentadas desde a eclosão com folhas de milho tratadas com extrato foram mais afetadas do que as que receberam esse tratamento a partir dos 10 dias de idade.

Souza \& Vendramim (2000a) compararam a bioatividade de extratos aquosos a $3 \%(\mathrm{p} / \mathrm{v})$ de três meliaceas, dentre estas, T. pallida, em relação à mosca-branca Bemisia tabaci (Gennadius) biótipo B, criada em tomateiro. Os extratos foram aplicados sobre ovos e ninfas, avaliando-se a mortalidade e a duração dessas fases. Verificou-se que, na fase de ovo, o extrato de T. pallida provocou maior mortalidade em relação æ̀ outras espécies avaliadas ( $A$. indica e $M$. azedarach). A maior mortalidade ninfal foi constatada no tratamento correspondente ao extrato de A. indica, seguindo-se os extratos de T. pallida e M. azedarach, sendo que nenhum dos extratos afetou a duração das fases de desenvolvimento.

Souza \& Vendramim (2001) estudaram a atividade de extratos de diferentes estruturas vegetais de $T$. pallida e $M$. azedarach sobre $B$. tabaci biótipo B. Foram utilizados extratos aquosos na concentração de $3 \%(p / v)$ aplicados sobre ovos e ninfas do inseto. Os autores avaliaram a mortalidade e duração de cada fase em função do tratamento com extrato. Em relação a $T$. pallida, verificourse que os extratos de ramos foram os únicos que provocaram mortalidade, tanto das fases de ovo como de ninfas, maior do que aquela observada na testemunha.

A eficiência de extratos aquosos de seis espécies de Trichilia, em comparação com o extrato aquoso de sementes de nim sobre $S$. frugiperda foi avaliada por Bogorni (2003). Inicialmente, foram selecionados os extratos de ramos e folhas de $T$. pallens e de ramos de $T$. pallida com sendo os mais eficientes sobre a praga em condições de laboratório. Esses extratos, juntamente com o inseticida lufenuron (Match CE), o óleo de nim e o extrato aquoso de sementes de nim foram testados sobre a lagarta-do-cartucho em condições de campo. Verificou-se que os extratos de folhas de T. pallens e de sementes de nim a 6,7\%, embora menos eficientes que 0 inseticida sintético 
lufenuron, reduzem o dano das lagartas à cultura do milho em condições de campo.

\subsection{Efeito de extratos de meliáceas sobre insetos minadores}

Extratos de plantas da família Meliaceae têm se mostrado ativos sobre várias espécies de insetos minadores. Estudos realizados por Webb et al. (1983) revelaram que o extrato aquoso de sementes de nim, em baixa concentração $(0,1 \%)$, mostrou-se eficiente para controle de moscas-minadoras do gênero Liriomyza.

Fagoonee \& Toory (1984) verificaram que em folhas de feijão infestadas por Liriomyza trifolii (Burguess) e tratadas com extrato aquoso de folhas de nim, na concentração de $2 \%$, houve redução na viabilidade larval do inseto e no número de adultos emergidos. Os autores também identificaram efeito deletério de extratos acetônicos de nim sobre larvas e pupas do inseto.

A inibição da alimentação e da oviposição de adultos de L. trifolii, em plantas de crisântemo pulverizadas com extrato etanólico de sementes de $A$. indica foram relatadas por Stein \& Parrella (1985). Foi verificado que o referido extrato, quando aplicado sobre as larvas, além de acarretar deformação nas pupas, reduziu a viabilidade desta fase do inseto.

Larew et al. (1985) testaram a atividade sistêmica de extratos etanólicos de sementes de nim sobre L. trifolii em crisântemo. Foram utilizados extratos nas concentrações de 0,01; 0,1 e 0,4\%, além da testemunha constituída de água mais espalhante adesivo, sendo este último também adicionado aos extratos. Quando as plantas foram tratadas com extrato na concentração de $0,4 \%$, foi observado um número reduzido de pupas em relação aos demais tratamentos, sendo que esta concentração juntamente com a de $0,1 \%$ causou menor emergência de adultos.

Rovesti \& Deseö (1991) realizaram um teste para avaliar a atividade do extrato aquoso de sementes de nim sobre larvas e ovos de Leucoptera 
malifoliella Costa, importante minador de folhas de macieira na Itália. Foi verificado que, mesmo na menor concentração utilizada ( $5 \mathrm{~g} / \mathrm{L})$, o extrato provocou $100 \%$ de mortalidade, quando aplicado sobre larvas de primeiro ínstar.

O efeito de extratos vegetais na sobrevivência das larvas do minadordos-citros (Phyllocnistis citrella Stainton) foi demonstrada por Bautista et al. (1998). Nesse trabalho, extratos aquosos de sementes de nim nas concentrações de 30 e $50 \mathrm{~g} / \mathrm{L}$ foram pulverizados sobre brotos de Citrus aurantifolia cv. Tahiti infestados com larvas da praga. Os autores verificaram mais de $70 \%$ de mortalidade das larvas, quando estas foram pulverizadas com o extrato na maior concentração (50 g/L) e sugeriram um possível efeito antialimentar, uma vez que a mortalidade máxima foi observada entre 48 e 72h após a aplicação.

Borad et al. (2001), também trabalhando com $P$. citrella, verificaram que extratos aquosos de folhas de nim na concentração de $10 \%$ foram capazes de reduzir a população dessa praga em plantas de $C$. aurantifolia.

Estudos envolvendo o efeito de extratos botânicos sobre a traça-dotomateiro são relativamente recentes. Os primeiros trabalhos nessa linha foram desenvolvidos por Ferracini et al. $(1991,1993)$ que testaram diversas plantas com potencial inseticida sobre o referido inseto, incluindo, dentre elas, $M$. azedarach. Num primeiro experimento, in vitro, lagartas de sexto dia foram alimentadas com folhas de tomateiro tratadas com extratos acetônicos e etanólicos da referida meliácea, registrando-se mortalidade larval de cerca de 88\%, quatro dias após a aplicação (Ferracini et al., 1991). Em outro teste, plantas de tomate envasadas foram pulverizadas com extratos aquosos e acetônicos de $M$. azedarach, verificando-se 52 e $62 \%$ de mortalidade larval, respectivamente (Ferracini et al., 1993).

Trindade et al. (2000) avaliaram o efeito de diferentes concentrações do extrato etanólico de amêndoa da semente de $A$. indica sobre ovos e lagartas da traça-do-tomateiro, em condições de laboratório. Os ovos pulverizados com 
extratos em concentrações variando de 62,5 a 1000 mg/L não foram afetados quanto ao período de incubação e viabilidade. Lagartas recém-eclodidas, alimentadas com folíolos de tomateiro tratados com o extrato em concentrações de 2, 4, 6 e $8 \mathrm{~g} / \mathrm{L}$, apresentaram, ao quarto dia, mortalidade de 82, 68, 95 e $100 \%$, respectivamente, sendo que, ao sexto dia, a mortalidade foi total nas quatro concentrações.

Brunherotto (2000) também demonstrou o efeito inseticida de extratos de nim sobre Tuta absoluta. Foram testados extratos aquosos de sementes dessa planta, juntamente com extratos de quatro estruturas (folhas, ramos, frutos verdes e frutos maduros) de $M$. azedarach. $O$ autor concluiu que todos os extratos afetaram o desenvolvimento do inseto, destacando-se o extrato de sementes de nim como o mais eficiente.

Thomazini et al. (2000), também trabalhando com T. absoluta, avaliaram o efeito de extratos aquosos de ramos e folhas de T. pallida sobre o desenvolvimento do inseto. Folíolos de tomateiro foram imersos nos extratos nas concentrações de 0,$1 ; 1,0$ e 5,0\%. Nesse teste foram avaliadas a duração e sobrevivência das fases larval e pupal, peso de pupas (machos e fêmeas) e porcentagem de deformação de pupas. No experimento com extrato de ramos foram avaliadas ainda, a porcentagem de adultos deformados e a longevidade de adultos não acasalados. Os autores concluíram que extratos aquosos de folhas e ramos de $T$. pallida prejudicam o desenvolvimento de $T$. absoluta, afetando principalmente, a fase larval e que o extrato de folhas apresenta maior atividade que o de ramos.

\subsection{Modo de ação dos compostos presentes em extratos de meliáceas}

Os estudos referentes ao modo de ação de compostos de meliáceas sobre insetos estão relacionados, principalmente a $A$. indica. Vários trabalhos têm demonstrado que compostos presentes em extratos dessa espécie, além de atuarem nos processos reprodutivos, comportamentais e, principalmente, 
inibirem a alimentação de insetos fitófagos, atuam como reguladores de crescimento (Isman et al., 1990; Martinez, 2002; Mordue (Luntz) \& Blackwell, 1993; Schumutterer, 1990).

De acordo com Koul et al. (1990), dentre os vários compostos isolados de $A$. indica até o momento, a azadiractina é o mais ativo, tendo por isso despertado o interesse de vários pesquisadores.

Mordue (Luntz) \& Blackwell (1993) caracterizaram a azadiractina como sendo um exemplo clássico de defesa natural das plantas. Os autores relataram que esse composto afeta a alimentação de forma primária, atuando sobre os quimiorreceptores do inseto e também reduzindo o aproveitamento alimentar, devido sua ação tóxica (efeito secundário). Como reguladora de crescimento, a azadiractina provoca alterações hormonais que podem levar o inseto à morte durante a troca de tegumento ou retardar a ecdise, impedindo que o mesmo atinja a fase adulta. Além de atuar como fago-deterrente e reguladora de crescimento, a azadiractina afeta negativamente a reprodução, uma vez que impede o desenvolvimento normal dos ovários, reduzindo a fecundidade e fertilidade dos ovos.

Estudos relacionados à utilização de extratos de nim e azadiractina aplicados topicamente sobre insetos têm sido realizados. Abraham \& Ambika (1979) estudaram o efeito de extratos de folhas e sementes dessa meliácea sobre a ecdise e vitelogênese em Dysdercus cingulatus Fabr. Extratos acetônicos, preparados a partir de $10 \mathrm{~g}$ de pó de cada estrutura vegetal, foram aplicados topicamente sobre o abdome de ninfas de terceiro, quarto e quinto ínstares, sendo os insetos controle, tratados somente com acetona. Todos os adultos obtidos após aplicação dos extratos apresentaram manutenção de caracteres ninfais como tarso bi-segmentado e asas rudimentares, além de se mostrarem incapazes de realizar a cópula. A mortalidade ninfal observada foi de 80 e $55 \%$ para extratos de semente e folhas, respectivamente. Nesse estudo, os ovários de todas as fêmeas foram dissecados e fixados para estudos histológicos. Morfologicamente, os ovaríolos dos insetos tratados mostraram 
sinais de degeneração, quando comparados aos ovaríolos dos insetos-controle. Os autores sugeriram que tanto extratos de folhas quanto de sementes de nim possuem alguma substância que interfere no processo de troca de tegumento do inseto.

Tanzubil \& McCaffery (1990) estudaram o efeito de azadiractina e de um extrato aquoso de sementes de nim sobre desenvolvimento de Spodoptera exempta Walker. Num primeiro teste, 0,01; 0,1; 1,0 e $10 \mu \mathrm{g}$ de azadiractina dissolvidos em $1 \mu$ de acetona foram aplicados na região mesotoráxica de lagartas do quinto ínstar, usando um tubo capilar. Insetos-controle receberam somente acetona. Com exceção da aplicação de $0,01 \mu \mathrm{g}$, todas as demais doses de azadiractina afetaram negativamente a sobrevivência e o crescimento larval. Em todos os casos, entretanto, a mortalidade foi retardada, indicando que esse composto não apresenta ação tóxica direta sobre os insetos. Para verificar 0 efeito de extratos aquosos de sementes de nim sobre o desenvolvimento do inseto, os autores utilizaram lagartas de quarto ínstar. Parte dessas lagartas foram imersas em extratos a 1 e $10 \%$ e posteriormente mantidas em folhas não tratadas de trigo, enquanto a outra parte foi confinada em folhas tratadas com esses mesmos extratos. Comparando com a testemunha (lagartas não tratadas criadas sobre folhas de trigo), o ganho de peso larval foi drasticamente reduzido tanto nas lagartas imersas, quanto naquelas que receberam folhas tratadas com extrato a $10 \%$. Em todos os casos, o extrato a $10 \%$ inibiu completamente a alimentação, provocando $100 \%$ de mortalidade das lagartas após cinco dias do tratamento. Das lagartas imersas em solução com menor concentração do extrato, $70 \%$ resultou em pupas defeituosas e nenhum adulto foi obtido no tratamento correspondente ao extrato nessa concentração.

Isman (1993) testou o efeito da azadiractina sobre o crescimento, consumo e aproveitamento alimentar em lagartas de seis espécies de noctuídeos tratadas topicamente com 50 e 100 ng de azadiractina em $1 \mu$ de acetona. Nesse trabalho, foram utilizadas 20 lagartas de quarto ínstar das 
seguintes espécies: Actebia fennica (Tausch), Mamestra configurata Walker, Peridroma saucia Hübner, Melanchra picta (Harr.), Spodoptera litura (Fab.) e Trichoplusia ni Hübner. Após o tratamento, as lagartas foram mantidas por três dias em dieta artificial. O peso das lagartas foi registrado antes e três dias após o tratamento. A dieta remanescente e as fezes das lagartas também foram pesadas. Para avaliação do efeito da azadiractina em aplicação tópica sobre as lagartas, foram determinadas a taxa de crescimento relativo, a taxa de consumo e a eficiência de conversão do alimento ingerido. Os tratamentos resultaram em redução significativa no ganho de peso, consumo e aproveitamento alimentar por parte dos insetos, sendo que $A$. fennica e $S$. litura foram menos afetadas do que as outras espécies.

O efeito da aplicação tópica do extrato metanólico de sementes de nim sobre formas imaturas de Pieris brassicae, importante praga de crucíferas, foi demonstrado por Osman (1993). Nesse trabalho, larvas de quinto ínstar foram tratadas topicamente com $10 \mu \mathrm{l}$ de extrato nas concentrações de 5; 2,5; 1,25 e $0,625 \%$ com auxílio de um microaplicador. Após o tratamento, as larvas foram individualizadas em copos plásticos invertidos sobre placas de Petri contendo discos de folha de repolho. As larvas foram pesadas a cada $24 \mathrm{~h}$ até que se transformassem em pupas. Suas fezes foram coletadas diariamente e, após secagem, também foram submetidas à pesagem. Os extratos também foram aplicados sobre pré-pupas e pupas com um e cinco dias de idade. Todas as larvas tratadas com extrato nas concentrações de 2,5 e 5\% morreram ou resultaram em adultos defeituosos. $O$ autor não verificou diferença na quantidade de excrementos e no ganho de peso das larvas tratadas com extrato em relação àquelas dos tratamentos-controle (metanol e larvas não tratadas). Entretanto, os extratos provocaram aumento na duração do período compreendido entre 0 quinto ínstar e o estágio adulto. Com relação \&̀s prépupas e pupas com um dia de idade, foram constatadas $\mathrm{CL}_{s} 50$ de 4,4 e $4,5 \%$ respectivamente, enquanto pupas com cinco dias de idade não foram afetadas pela aplicação dos extratos. 
A atividade biológica de extratos metanólicos de Trichilia americana foi testada por Wheeler \& Isman (2001) sobre lagartas de S. litura. Foram realizados testes envolvendo o consumo de dieta e folhas de couve tratadas, além da aplicação tópica e injeção dos extratos na hemocele dos insetos. Os autores verificaram efeito negativo dos extratos sobre a preferência alimentar e desenvolvimento dos insetos, quando os mesmos foram fornecidos por meio do alimento. Por outro lado, não foi observado efeito tóxico, quando os extratos foram aplicados topicamente ou injetados diretamente na hemocele das lagartas.

Além do efeito da aplicação direta dos extratos sobre os insetos, vários estudos têm demonstrado a capacidade de translocação na planta apresentada por compostos presentes nos mesmos. Esses estudos são, na maioria, referentes a $A$. indica e comprovam que quando extratos dessa meliácea são aplicados no solo ou em partes isoladas da planta, os compostos ativos podem ser absorvidos, atingindo a parte aérea.

$O$ efeito sistêmico de extratos aquosos de sementes de nim sobre insetos da ordem Lepidoptera foi demonstrado por Meisner et al. (1987). Os autores estudaram a resposta de lagartas de Earias insulana Boisd. quando plântulas de algodão foram tratadas com extratos de sementes de nim em diferentes concentrações. Os pecíolos de cotilédones pré-germinados foram imersos por $24 \mathrm{~h}$ em extrato a 0,$5 ; 0,25$ e $0,1 \%$. Após este período, as plântulas foram retiradas das soluções, o excesso de líquido foi drenado e as plântulas transferidas para placas de Petri contendo uma fina camada de serragem para absorção dos excrementos das lagartas. Utilizaram-se lagartas de sete a oito dias, as quais foram transferidas para o interior das placas para que se alimentassem das plântulas de algodão. $O$ peso das lagartas foi registrado após 24,48 e $72 \mathrm{~h}$ da instalação do experimento. Verificourse que, após $72 \mathrm{~h}$ de alimentação, o peso larval em todas as concentrações testadas foi reduzido pela metade quando comparado com aquele observado sobre plântulas não tratadas. 
Larew et al. (1985) testaram a atividade sistêmica de extratos etanólicos de sementes de nim sobre L. trifolli em crisântemo. Quando o extrato, na concentração de $0,4 \%$ foi aplicado no solo, provocou mortalidade significativa de larvas do último ínstar e pupas da mosca-minadora. Os autores relataram que três a 21 dias após o tratamento das plantas com extrato de nim a 0,1\%, foi observada mortalidade significativa entre os estágios pupal e adulto do inseto, mostrando que o efeito inseticida do extrato aplicado no solo se prolongou por até três semanas.

Osman \& Port (1990) estudaram o efeito sistêmico de substâncias presentes em sementes de nim sobre $P$. brassicae. Além dos extratos, o pó de sementes, adicionado ao substrato, também foi testado sobre os danos provocados pela praga em plantas de repolho. Foram realizados três experimentos, sendo que o primeiro consistiu da aplicação de 16, 8, 4 e $2 \mathrm{~g}$ de pó de sementes misturados ao substrato destinado ao plantio das mudas. Cada planta foi infestada, 15 dias após o tratamento, com quatro lagartas (terceiro ínstar) de $P$. brassicae e individualizadas em gaiolas. Após $24 \mathrm{~h}$ da infestação, as plantas foram avaliadas e os danos quantificados através de notas. Houve diferença significativa nos danos observados em plantas tratadas, quando comparadas com o controle (plantas cultivadas em substrato sem adição de pó de sementes de nim). Nesse experimento, todas as lagartas que se alimentaram nas plantas tratadas morreram após dois ou três dias, enquanto aquelas que se alimentaram nas plantas-controle completaram 0 seu desenvolvimento e originaram adultos normais. Num segundo experimento, os tratamentos foram aplicados da mesma maneira que no anterior, utilizando-se, entretanto, 9,38; 4,70; 2,34 e 1,17 $\mathrm{g}$ de pó por $\mathrm{kg}$ de substrato, além de um controle sem adição do produto. A infestação foi realizada em gaiolas maiores contendo todos os tratamentos, permitindo que as lagartas pudessem escolher o substrato para alimentação. Todas as lagartas foram retiradas das gaiolas, $24 h$ após a infestação e criadas em folhas de repolho não tratadas até a pupação. Observaram-se, nos tratamentos correspondentes के duas maiores 
concentrações de pó de sementes de nim, danos significativamente menores do que nas plantas-controle. Por sua vez, o tratamento correspondente a $1,17 \mathrm{~g}$ de pó não diferiu da testemunha. Para avaliação do efeito de extratos aplicados no solo, mudas de repolho foram tratadas com $10 \mathrm{ml}$ de soluções aquosas obtidas a partir de extrato metanólico de sementes de nim (10; 5; 2,5 e 1,25\%). A infestação foi feita aos dois e 15 dias depois de as plantas terem sido tratadas com os extratos. Após $24 \mathrm{~h}$ da infestação, foi feita avaliação do dano e as lagartas foram recolhidas e mantidas em folhas não tratadas até a pupação. Em relação aos danos provocados pelas lagartas, somente 0 tratamento correspondente a $1,25 \%$ não diferiu da testemunha, sendo os dois considerados os mais danificados. Não houve diferença significativa entre os danos provocados em plantas infestadas aos dois ou 15 dias após o tratamento. Os autores sugeriram que a aplicação de sementes de nim tanto na forma de pó como de extratos no solo é recomendável, podendo apresentar maior eficiência em relação à aplicação na parte aérea, uma vez que os compostos ativos presentes no produto são altamente sensíveis àradiação.

Rovesti \& Deseö (1991) testaram a atividade sistêmica de extratos aquosos de sementes de nim sobre L. malifoliella. A translocação vascular dos ingredientes ativos presentes no extrato foi verificada por aplicações no solo e nas folhas mais baixas da planta. Os autores relataram que, quando aplicados no solo, os extratos foram absorvidos pelas raízes e translocados para a parte aérea. $O$ número de pupas nas plantas tratadas foi significativamente menor quando comparadas à testemunha, sendo que os efeitos mais drásticos dos tratamentos sobre o desenvolvimento larval foram verificados no terço inferior das plantas. Quando aplicado nas folhas mais baixas, a translocação do ingrediente ativo até as folhas mais altas da planta também foi efetiva.

Holmes \& Hassan (1999) avaliaram a ação sistêmica do extrato de sementes de nim aplicado em plantas de mini-rosas infestadas pelo pulgão Myzus persicae L. Para realização do teste, utilizou-se uma formulação em pó, obtida de um extrato metanólico de sementes de nim contendo 1,2\% de 
azadiractina. Foram utilizados quatro tratamentos (extrato de nim a 60, 120 e 180 ppm de azadiractina e água), aplicados diretamente no solo na quantidade de $125 \mathrm{ml} /$ planta. Antes da aplicação dos tratamentos, o número de pulgões em cada planta foi registrado. As plantas tratadas foram transferidas para gaiolas $\mathrm{e}$ a avaliação do incremento populacional foi realizada ìs $24,48,72 \mathrm{~h}$ e uma semana após a aplicação dos extratos. Os autores observaram que na concentração de 60 ppm, houve redução no número de pulgões nas primeiras 24h. Após esse período, a população aumentou, atingindo, em uma semana um número semelhante ao observado no início do teste. Com relação à concentração de 120 ppm, a população de afídeos se manteve baixa, durante todo o período avaliado e a 180 ppm, o número de pulgões foi reduzido a zero, 24h após a aplicação do extrato.

Shivashankar et al. (2000) estudaram a efetividade de produtos à base de nim, aplicados de forma sistêmica no manejo da lagarta Opsina arenosella Walker. Primeiramente, quatro formulações disponíveis no mercado (Soluneem, Neemark, Nimbecidine e Neemazal F) foram testadas quanto à sua velocidade de translocação em plantas de coqueiro. Nesse teste, $10 \mathrm{ml}$ de soluções contendo 150 ppm de cada produto foram aplicados na base do tronco com o auxílio de uma seringa de $20 \mathrm{ml}$. Foram feitas observações quanto à taxa de absorção a intervalos de 6h por um período de 24h. A absorção de Neemark, Nimbecidine e Neemazal F em 24h foi de 1,0;0,5 e 2,0 ml, respectivamente. Por outro lado, a absorção de Soluneem se completou em 18h, sendo essa formulação escolhida para realização dos testes sobre O. arenosella. Para monitorar o movimento do produto na planta, uma mistura de azul de metileno (3 g) e Soluneem (1500 ppm) dissolvidos em $20 \mathrm{ml}$ de água foi aplicada em duas plantas. Após $24 \mathrm{~h}$, as plantas foram cortadas e abertas para verificar 0 movimento do corante. O aparecimento da cor azul nos vasos do xilema a diferentes alturas foi usado como indicador para a translocação do Soluneem. 0 corante misturado ao produto foi verificado nos vasos do xilema a uma altura de 6,3 $\mathrm{m}$ após $24 \mathrm{~h}$. De posse de todas essas informações, plantas de coqueiro 
foram infestadas com a praga e tratadas sistemicamente com $10 \mathrm{ml}$ de solução contendo 3000 ppm de Soluneem. Plantas tratadas com $10 \mathrm{ml}$ de água foram utilizadas como controle. Os autores verificaram que a maioria das lagartas das plantas tratadas morreu antes de completarem o segundo ínstar. Após 15 dias da aplicação dos tratamentos, as lagartas das plantas-controle, se apresentavam maiores e mais ativas do que aquelas que se alimentaram nas plantas tratadas. Houve redução significativa na população de lagartas nas plantas tratadas e a área foliar consumida em plantas não tratadas $\left(152 \mathrm{~cm}^{2}\right)$ foi significativamente maior do que nas plantas que receberam tratamento (57 $\mathrm{cm}^{2}$ ). Os autores atribuíram os efeitos provocados nas lagartas à presença do inseticida nas folhas, apesar de o mesmo ter sido aplicado no solo.

A ação translaminar de um inseticida àbase de extrato de sementes de nim foi testada por Verkerk et al. (1998) sobre os pulgões $M$. persicae e Brevicoryne brassicae (L.). $O$ produto foi aplicado na superfície adaxial de folhas de repolho, enquanto ninfas dos pulgões foram confinadas na superfície oposta por meio de gaiolas. Após 96h da aplicação dos tratamentos, os autores registraram $100 \%$ de mortalidade em folhas tratadas, sendo que no tratamento correspondente à testemunha (água destilada) a mortalidade de pulgões foi nula.

\subsection{Controle biológico da traça-do-tomateiro com parasitóides do gênero}

\section{Trichogramma}

Considerando os programas de manejo integrado de T. absoluta, o uso de parasitóides do gênero Trichogramma já é uma realidade em alguns países, a exemplo da Colômbia, onde liberações inundativas de Trichogramma exiguum Pinto \& Platner contribuíram para redução significativa da população desta praga e do número de aplicações de inseticidas na cultura do tomateiro (Navarro, 1988). 
Trabalhos realizados na Argentina demonstraram que Trichogramma pretiosum e Trichogramma rojasi estão entre as espécies entomófagas com maior potencial para o controle biológico da traça-do-tomateiro em ambientes protegidos. Esses insetos foram encontrados parasitando tanto ovos de $T$. absoluta, como de outros lepidópteros comuns em plantios de tomateiro (Botto, 1999).

No Brasil, a liberação inundativa desses microimenópteros para controle da traça-do-tomateiro foi implementada na região do Sub-Médio São Francisco, a partir de tecnologia adaptada da Colômbia (Roa \& Jimenez, 1992) e, por determinado período, foi utilizada com sucesso em lavouras de tomate rasteiro (Haji et al., 1995).

No Distrito Federal, a experiência com T. pretiosum teve início em 1992, quando se observou que a porcentagem de frutos de tomateiro danificados em área com controle biológico foi de quatro a 10 vezes inferior àquela determinada em área de controle químico exclusivo (França et al., 1993).

Villas Bôas \& França (1996) destacaram a potencialidade do uso de parasitóides do gênero Trichogramma para controle de $T$. absoluta em cultivos protegidos de tomate, uma vez que esses insetos foram eficientes em reduzir a população da praga a níveis satisfatórios e a um custo menor do que o observado no controle químico exclusivo.

Em experimento desenvolvido em casa de vegetação, Domingues et al. (2003) atribuíram ao parasitóide T. pretiosum um controle de $87 \%$ sobre a traça-do-tomateiro, valor superior ao exercido pelo controle químico $(41,7 \%)$. Os autores sugerem que a tecnologia de utilização desse parasitóide seja repassada aos produtores, uma vez que além de proporcionar bons resultados de controle, essa técnica propicia a manutenção do equilíbrio ecológico, evitando problemas ambientais e ao agricultor. 


\subsection{Efeito de extratos de meliáceas sobre insetos do gênero Trichogramma}

A maioria dos trabalhos referentes ao controle de pragas com produtos botânicos destaca que o uso dessas substâncias é compatível com outras táticas de manejo, principalmente com o controle biológico. Entretanto, vários autores têm demonstrado variações na resposta de inimigos naturais à aplicação de tais produtos.

Klemm \& Schmutterer (1993) mostraram que a pulverização de ovos de Plutella xylostela (L.) com óleo de sementes de nim a $2 \%$ reduziu o número de ovos parasitados por Trichogramma principium em laboratório e por $T$. pretiosum em condição de campo.

Cano \& Gladstone (1994) determinaram o efeito de Nim-20, um inseticida botânico fabricado com base em extratos de semente de $A$. indica, sobre o parasitismo de ovos de Helicoverpa zea (Bod.) por T. pretiosum em cultivo de melão. Os tratamentos se constituíram de Nim-20 nas concentrações de 2,5 e 1,5 g/L, sendo pulverizados 51 L/parcela, além de uma testemunha sem controle. Nesse teste não foi verificado efeito negativo da aplicação de Nim-20 sobre o parasitismo. Apesar de terem utilizado doses do produto menores do que as recomendadas para controle de Diaphania spp., importante praga na cultura do melão, os autores sugerem que, além de preservarem os parasitóides, essas doses baixas poderiam controlar as lagartas que porventura tivessem "escapado" do parasitismo.

Raguran \& Singh (1999) testaram o óleo de sementes de nim em concentrações de 5,0; 2,5; 1,2; 0,6 e 0,3\% sobre a oviposição, alimentação, fecundidade e desenvolvimento de Trichogramma chilonis. O óleo de sementes de nim apresentou ação deterrente quanto à oviposição e alimentação do parasitóide. Foi verificado que o produto também causou mortalidade tanto em insetos que se alimentaram com mel tratado, como naqueles que entraram em contato com ovos tratados do hospedeiro. O óleo de sementes de nim, 
entretanto, não causou esterilidade nos adultos e os estágios de desenvolvimento do parasitóide no interior de ovos tratados não foram aparentemente afetados pelo produto. De acordo com os resultados obtidos nesse trabalho, os autores sugerem que para liberações inundativas de $T$. chilonis, o pré-tratamento da cultura com óleo de sementes de nim deve ser evitado; por outro lado, o tratamento da cultura com o produto, após o parasitismo pode conservar os parasitóides. É recomendável que antes do tratamento da cultura com produtos à base de nim, sejam feitas amostragens para determinar o estágio em que o parasitóide se encontra no campo, visando àaplicação em épocas mais apropriadas.

A toxicidade de 11 inseticidas sobre $T$. chilonis foi testada por Reddy \& Manjunatha (2000). Dentre os produtos testados, o Nimbecide, um formulado à base de azadiractina, foi considerado o menos tóxico, já que o mesmo não causou mortalidade dessa espécie de parasitóide nas primeiras $48 \mathrm{~h}$ após sua aplicação.

Hohmann et al. (2002) estudaram o efeito do extrato aquoso de sementes e do óleo de nim sobre T. pretiosum. Os resultados obtidos pelos autores demonstraram que o pré-tratamento de ovos do hospedeiro com o extrato na concentração de $15 \%$ reduziu drasticamente a oviposição do parasitóide. Por outro lado, a capacidade de parasitismo de T. pretiosum não foi afetada por esse extrato em concentrações mais baixas (3 e 1,5\%). Nos testes em que o tratamento dos ovos foi realizado após o parasitismo, o extrato aquoso (15\%) e o óleo de nim $(0,25 \%)$ reduziram a emergência do parasitóide em 80 e $20 \%$, respectivamente.

O efeito de extratos de outras meliáceas sobre insetos do gênero Trichogramma ainda é pouco conhecido. Gonçalves-Gervásio \& Vendramim (2002, 2003) verificaram que extratos aquosos e clorofórmicos de folhas de $T$. pallida em concentrações de até $10 \%$ podem ser compatíveis com a utilização do parasitóide T. pretiosum no controle de pragas. 


\section{MATERIAL E MÉTODOS}

Os experimentos foram realizados, em laboratório e casa de vegetação, no Setor de Plantas Inseticidas do Departamento de Entomologia, Fitopatologia e Zoologia Agrícola da ESALQ/USP em Piracicaba/SP, com o objetivo de avaliar o efeito de extratos das meliáceas Trichilia pallida Swartz e Azadirachta indica A. Juss (nim) sobre a traça-do-tomateiro Tuta absoluta (Meyrick, 1917) (Lepidoptera: Gelechiidae) e o parasitóide de ovos Trichogramma pretiosum Riley, 1879 (Hymenoptera: Trichogrammatidae).

\subsection{Obtenção e criação dos insetos}

A criação da traça-do-tomateiro foi conduzida em laboratório, seguindo metodologia adaptada de Pratissoli (1995), utilizando folhas de tomateiro cv. Santa Clara. Para manter a turgidez das folhas, seus pecíolos foram colocados em recipientes plásticos contendo água, dispostos em bandejas (plásticas) de criação. Quando as folhas se tornavam inadequadas (secas ou muito danificadas), estas eram colocadas sobre folhas novas, de forma que as lagartas deixassem as folhas antigas e passassem a se alimentar das novas. Após três dias, as folhas velhas (contendo pupas) eram transferidas para frascos de vidro $(500 \mathrm{~g})$ cobertos por tecido fino (voil) para obtenção dos adultos. A partir do início da emergência, os frascos contendo adultos eram distribuídos no interior de gaiolas teladas ( $30 \mathrm{~cm}$ de diâmetro $\times 36 \mathrm{~cm}$ de altura), o voil era retirado, permitindo assim que os mesmos fossem liberados no interior das gaiolas. Folhas de tomateiro com o pecíolo imerso em água eram 
colocadas no interior das gaiolas para servirem de substrato para postura. As folhas com ovos eram substituídas a cada dois dias, sendo então transferidas para as bandejas de criação.

Os parasitóides foram mantidos em tubos de vidro $(2,5 \mathrm{~cm}$ de diâmetro e $8,5 \mathrm{~cm}$ de altura), tampados com filme plástico PVC e multiplicados sobre ovos inférteis do hospedeiro alternativo, a traça-das-farinhas Anagasta kuehniella (Zeller, 1879). Os ovos do hospedeiro foram obtidos junto ao laboratório de Biologia de Insetos do Departamento de Entomologia, Fitopatologia e Zoologia Agrícola da ESALQ. Esses ovos foram esterilizados sob lâmpada germicida, por aproximadamente 30 minutos, evitando assim a eclosão das lagartas, que poderiam eventualmente se alimentar dos demais ovos, mesmo daqueles já parasitados. Os ovos foram colados em cartelas confeccionadas com cartolina azul $(1,5 \times 7,0 \mathrm{~cm})$, mediante uma solução aquosa de goma arábica a 10\% e submetidos ao parasitismo em tubos de vidro. Após o parasitismo, as cartelas foram transferidas para novos tubos até a emergência da geração seguinte, dando início a um novo ciclo. Como alimento para os adultos foi utilizada uma gota de mel puro, depositada na parede interna de cada tubo de criação.

\subsection{Obtenção do material vegetal para preparo dos extratos}

As folhas de $T$. pallida foram coletadas em área de mata da ESALQ/USP, enquanto as sementes de $A$. indica, foram obtidas junto à empresa Nim do Brasil Ltda., em Campinas, SP.

Após secagem em estufa com circulação de ar (a $40^{\circ} \mathrm{C}$, por cerca de 48 h), as folhas de T. pallida, bem como as sementes de nim, foram trituradas em moinho de facas para obtenção dos pós vegetais. Esses foram acondicionados em frascos de vidro hermeticamente fechados para posterior preparo dos extratos. 


\subsection{Testes preliminares}

\subsubsection{Determinação das concentrações adequadas dos extratos a serem utilizadas nos experimentos}

Com o objetivo de estabelecer as concentrações de extrato mais adequadas para os estudos com a traça-do-tomateiro, foram realizados testes preliminares utilizando-se extratos aquosos de sementes de nim em concentrações que variaram de 0,5 a $10 \%(\mathrm{p} / \mathrm{v})$.

\subsubsection{Preparo dos extratos}

Para preparo dos extratos aquosos, o pó de sementes de nim foi adicionado à água destilada, nas proporções de 0,5; 1,0; 5,0 e 10,0 g por 100 $\mathrm{ml}$. Essas misturas foram mantidas em aparelho ultra-som por 40 minutos para extração dos compostos hidrossolúveis. Após esse processo, o material foi filtrado, obtendo-se os extratos nas concentrações desejadas para realização dos testes.

\subsubsection{Ação translaminar}

Nesse teste, conduzido em casa de vegetação, foram aplicados extratos nas concentrações de 0,5; 1,0 e 5,0\%, além de uma testemunha representada por água destilada. Foram utilizadas plantas de tomateiro com aproximadamente 25 dias de idade, sendo que em cada uma, foram marcados quatro folíolos do terço médio, os quais receberam três lagartas recémeclodidas da traça-do-tomateiro. Após o aparecimento das minas, os tratamentos (extratos e água) foram aplicados na superfície adaxial dos folíolos com o auxílio de um pincel. Após a evaporação do excesso de umidade na superfície do folíolo, este foi protegido por uma gaiola constituída de uma placa 
de acrílico (6 $\mathrm{cm}$ de diâmetro e $2 \mathrm{~cm}$ de altura) a qual teve o fundo removido e protegido por um tecido fino (voil) para promover melhor aeração no interior da mesma. Essa gaiola foi utilizada com o objetivo de evitar a fuga das lagartas e permitir o acompanhamento do desenvolvimento larval da traça.

A aplicação dos tratamentos foi repetida após sete e 14 dias, sendo esta última realizada apenas nos folíolos onde $o$ inseto ainda se encontrava na fase larval. Antes da segunda aplicação (sete dias após a infestação), foi feita uma avaliação do desenvolvimento das minas causadas pelas lagartas nos folíolos. Seguindo metodologia proposta por Picanço et al. (1995), as minas foram classificadas em pequenas (menos que $0,5 \mathrm{~cm}$ de comprimento), médias $(0,5 \mathrm{a}$ $1,0 \mathrm{~cm}$ de comprimento) e grandes (mais de $1,0 \mathrm{~cm}$ de comprimento). Quando os folíolos infestados estavam totalmente danificados, as lagartas eram transferidas para novos folíolos e após a penetração das mesmas no mesofilo foliar, o tratamento era novamente aplicado. O número de pupas obtido em cada tratamento foi registrado e, a partir desse dado, foi calculada a viabilidade larval.

$O$ experimento seguiu o delineamento inteiramente casualizado com quatro tratamentos (três concentrações do extrato e testemunha) e cinco repetições, sendo que cada repetição foi representada por uma planta.

\subsubsection{Ação sistêmica}

Esse teste foi conduzido em casa de vegetação, utilizando-se mudas de tomateiro em vasos com capacidade para aproximadamente $3 \mathrm{~L}$ de substrato. Após 20 dias do transplante, os tratamentos foram aplicados. Todos os vasos receberam $100 \mathrm{ml}$ de extrato, nas concentrações de 0,5; 1,0; 5,0 e 10,0\%, além de uma testemunha que recebeu a mesma quantidade de água.

Após 24h da aplicação dos tratamentos, quatro folíolos de tomateiro, em cada vaso, foram infestados com três lagartas recém-eclodidas de $T$. absoluta e protegidos com uma gaiola semelhante àquela utilizada no item anterior.

No decorrer do experimento, as irrigações foram feitas, tomando-se o 
cuidado de colocar a mesma quantidade de água por vaso, procurando-se evitar o excesso de água de forma que os extratos não se perdessem por lixiviação. A aplicação dos tratamentos foi repetida após sete e 14 dias, sendo que aos sete dias foi feita avaliação do desenvolvimento das minas.

O experimento seguiu o delineamento inteiramente casualizado com cinco tratamentos (quatro concentrações do extrato e testemunha) e cinco repetições.

\subsubsection{Ação de contato}

Nesse teste, realizado em laboratório (T: $25 \pm 2^{\circ} \mathrm{C}$; UR: $70 \pm 10 \%$; fotofase de $12 \mathrm{~h}$ ), foram feitas aplicações tópicas dos extratos em lagartas de segundo ínstar (seis dias de idade), utilizando-se uma microsseringa. Foi aplicado, aproximadamente, $0,1 \mu \mathrm{l}$ de extrato no dorso de cada lagarta, sendoque no tratamento testemunha, estas receberam $0,1 \mu \mathrm{l}$ de água destilada. Os insetos foram mantidos em tubos de vidro $(2,5 \mathrm{~cm}$ de diâmetro e $8,5 \mathrm{~cm}$ de altura), contendo um folíolo de tomateiro com o pecíolo envolvido em algodão umedecido. O experimento seguiu o delineamento inteiramente casualizado com quatro tratamentos (extratos nas concentrações de 1, 5 e 10\% e testemunha) e cinco repetições. Cada repetição foi constituída por cinco tubos contendo três lagartas cada um, totalizando 15 lagartas por repetição. Foram feitas avaliações diárias da mortalidade até que as larvas atingiram o estágio de pupa.

\subsubsection{Avaliação da atividade de extratos orgânicos de $T$. pallida sobre $T$. absoluta}

\subsubsection{Preparo dos extratos orgânicos}

Foram utilizados quatro extratos orgânicos de folhas de T. pallida (metanólico, etanólico, clorofórmico e hexânico) com o objetivo de selecionar, 
dentre os mesmos, aquele que fosse mais ativo sobre a traça-do-tomateiro. Para o preparo desses extratos, $15 \mathrm{~g}$ do pó de folhas de T. pallida foram adicionados a $200 \mathrm{ml}$ de cada solvente. Essas misturas foram mantidas em aparelho ultra-som por 40 minutos para extração dos compostos ativos. Após esse período, os extratos foram submetidos a um sistema de filtragem a vácuo e os solventes foram evaporados em rotavapor. Os resíduos obtidos em cada extração foram diluídos em $15 \mathrm{ml}$ de acetona e armazenados em geladeira para posterior utilização nos bioensaios. Como, em princípio, foram utilizadas $15 \mathrm{~g}$ do pó vegetal, cada ml da solução final (resíduo + acetona) correspondeu a $1 \mathrm{~g}$ do pó de folhas de T. pallida.

\subsubsection{Testes de bioatividade}

Foram realizados dois testes envolvendo os quatro extratos orgânicos de folhas de T. pallida, além do extrato aquoso dessa espécie e o de sementes de nim.

Primeiramente, todos os extratos foram testados em relação a dois tratamentos-controle: água e água + acetona. A inclusão desse segundo tratamento-controle teve o objetivo de verificar se a acetona utilizada para diluição dos extratos poderia afetar os insetos. No segundo teste, o tratamento água + acetona foi excluído, uma vez que os dados obtidos nesse tratamento não diferiram daquele obtido no tratamento com água. Além disso, o tratamento com extrato aquoso de nim também foi suprimido com o objetivo de facilitar a discriminação entre os extratos orgânicos, dada a alta eficiência demonstrada por aquele extrato em relação aos demais, no primeiro teste.

Para verificação do efeito dos extratos orgânicos sobre a traça-dotomateiro, $5 \mathrm{ml}$ de cada solução (extrato + acetona) foram diluídos em $100 \mathrm{ml}$ de água. Considerando que a solução foi obtida a partir de $15 \mathrm{~g}$ do pó vegetal, a utilização de 1/3 da mesma (5 ml), possibilitou a obtenção de um extrato na concentração de $5 \%$. Os extratos aquosos de nim e de T. pallida foram 
preparados a partir da adição de $5 \mathrm{~g}$ do pó de cada material vegetal em $100 \mathrm{ml}$ de água, sendo essa mistura mantida em aparelho de ultra-som por 40 minutos, seguido de filtragem.

Para aplicação dos tratamentos, folíolos de tomateiro foram imersos por dois segundos nos diferentes extratos. Após a eliminação do excesso de umidade, cada folíolo foi infestado com três lagartas recém-eclodidas de $T$. absoluta e transferido para placas plásticas $(6 \mathrm{~cm}$ de diâmetro e $2 \mathrm{~cm}$ de altura). Os folíolos tiveram seu pecíolo envolvido em algodão umedecido para manutenção da turgescência. A cada dois dias, era realizada a troca dos folíolos para manutenção da qualidade do substrato alimentar para as lagartas, sendo que a cada troca, os folíolos novos eram submetidos aos mesmos tratamentos descritos acima. A mortalidade larval foi avaliada diariamente até o sétimo dia.

O primeiro experimento seguiu o delineamento inteiramente casualizado com oito tratamentos (quatro extratos orgânicos e um aquoso de T.pallida, extrato aquoso de sementes de nim e testemunhas água e água + acetona) e cinco repetições. No segundo este foram excluídos os tratamentos extrato aquoso de nim e a testemunha água + acetona. Cada repetição foi constituída por cinco placas contendo três lagartas cada uma, totalizando 75 lagartas por tratamento.

\subsection{Determinação do modo de ação de extratos de folhas de T. pallidasobre T. absoluta}

A partir dos resultados obtidos nos testes anteriores, selecionou-se o extrato clorofórmico de folhas de T. pallida para, juntamente com o extrato aquoso ser avaliado quanto æ̀s atividades translaminar, sistêmica e de contato sobre $T$. absoluta. A metodologia utilizada nos testes referentes ao modo de ação foi a mesma descrita nos itens 3.3.1.2, 3.3.1.3 e 3.3.1.4. Além da viabilidade larval, nesses testes as pupas obtidas em cada tratamento foram coletadas e mantidas em laboratório até a emergência dos adultos. Assim, foi possível avaliar a duração, viabilidade e peso de pupas machos e fêmeas. 
Em todos os testes, os extratos aquoso e clorofórmico de folhas de $T$. pallida foram comparados com o extrato de sementes de nim e com os tratamentos-testemunha (água e água + acetona).

Como, em princípio, os extratos de T. pallida não apresentaram atividade satisfatória nas concentrações selecionadas nos testes preliminares (com extrato de sementes de nim), os experimentos referentes ao modo de ação foram repetidos aumentando-se a concentração dos mesmos, e mantendo-se a concentração do extrato aquoso de sementes de nim.

\subsection{Efeito de extratos de meliáceas sobre o parasitóide T. pretiosum}

Nos testes envolvendo o parasitóide T. pretiosum, além dos extratos de folhas de T. pallida (aquoso e clorofórmico) e do extrato aquoso de sementes de nim, foi incluído um tratamento adicional constituído por uma solução de água mais acetona (2\%). Esse tratamento foi inserido nos testes para verificar um possível efeito da acetona utilizada na diluição do extrato clorofórmico sobre o comportamento e desenvolvimento do parasitóide.

\subsubsection{Tratamento dos ovos antes do parasitismo}

Foram realizados testes com e sem chance de escolha, envolvendo os extratos de folhas de $T$. pallida (aquoso e clorofórmico) e de sementes de nim (aquoso) na concentração de $10 \%$ p/v, além da solução (água + acetona) e da testemunha (água).

\subsubsection{Teste com chance de escolha}

No teste com chance de escolha, foram utilizadas cartelas de cartolina na cor azul $\left(0,5 \mathrm{~cm}^{2}\right)$ contendo, em média 250 ovos de $A$. kuehniella, sendo parte dessas cartelas tratada com os diferentes extratos ou com a solução (água + 
acetona) e parte com água destilada (testemunha).

Duas cartelas de ovos, sendo uma representada pela testemunha e a outra pelos tratamentos com extrato ou pela solução, foram fixadas nas extremidades opostas de um retângulo de cartolina $(1,5 \times 3,0 \mathrm{~cm})$ e inseridas em tubos de vidro (2,5 cm de diâmetro e $8,5 \mathrm{~cm}$ de altura), no interior dos quais foram liberadas cinco fêmeas recém-emergidas do parasitóide. Na parede interna de cada tubo, foi depositada uma gota de mel puro para servir de alimento para as fêmeas do parasitóide. Os tubos foram mantidos em câmara climática $\left(25 \pm 2^{\circ} \mathrm{C}\right.$, UR $70 \%$ e fotofase de $14 \mathrm{~h}$ ) por $24 \mathrm{~h}$. Após esse período, as cartelas foram transferidas para novos tubos e utilizadas para avaliação do parasitismo e emergência. As fêmeas remanescentes de cada tratamento foram observadas diariamente para avaliação da longevidade.

\subsubsection{Teste sem chance de escolha}

Esse teste foi semelhante ao anterior, sendo, entretanto, utilizada apenas uma cartela $\left(1 \mathrm{~cm}^{2}\right)$ contendo aproximadamente 500 ovos de A. kuehniella referente a cada tratamento para cada grupo de cinco fêmeas.

\subsubsection{Tratamento dos ovos após o parasitismo}

Para a realização desse teste, foram utilizadas cartelas $(0,5 \times 1,0 \mathrm{~cm})$ contendo aproximadamente 250 ovos de $A$. kuehniella, as quais foram submetidas ao parasitismo por $24 \mathrm{~h}$, antes do tratamento. Os tratamentos consistiram da imersão dessas cartelas por dois segundos nos extratos de folhas de T. pallida (aquoso e clorofórmico) e de sementes de nim (aquoso) na concentração de $10 \%$ p/v e na solução (água + acetona). Como testemunha, foram utilizadas cartelas tratadas com água destilada. Os tratamentos foram aplicados as 24, 72 e 168h após o parasitismo, correspondendo à fases de ovolarva, pré-pupa e pupa do parasitóide, respectivamente (Cônsoli et al., 1998). 
Após o tratamento, as cartelas foram individualizadas em tubos de vidro $(2,5 \mathrm{~cm}$ de diâmetro e $8,5 \mathrm{~cm}$ de altura) e mantidas em câmara climática $\left(25 \pm 2^{\circ} \mathrm{C}\right.$, UR $70 \%$ e fotofase de $14 \mathrm{~h}$ ). Foram feitas avaliações quanto ao número de ovos com sintoma de parasitismo, ou seja, ovos escuros devido àdeposição de corpos de urato no interior do córion do hospedeiro. Como esse sintoma aparece no início da fase de pré-pupa do parasitóide, ovos tratados após as 72h já apresentavam essa característica. Além do número de ovos escuros, também foi avaliada a porcentagem de emergência. $O$ delineamento utilizado foi $O$ inteiramente casualizado em esquema fatorial (extrato $x$ fases de desenvolvimento do parasitóide) com 10 repetições. Após a emergência, foram selecionadas 20 fêmeas por tratamento para avaliação do efeito dos extratos sobre uma segunda geração do parasitóide. Essas fêmeas foram individualizadas em tubos de vidro contendo uma cartela com aproximadamente 250 ovos de A. kuehniella, onde permaneceram por um período de $24 \mathrm{~h}$. Como alimento para as fêmeas, na parede interna de cada tubo, foi depositada uma gota de mel puro. Nesse teste, foram avaliados o número de ovos parasitados, a porcentagem de emergência e a longevidade das fêmeas selecionadas.

\subsection{Análise estatística}

Os dados foram submetidos à análise de variância e no caso de efeito significativo, as médias foram comparadas pelo teste de Tukey $(P \leq 0,05)$. Nas situações onde ocorreram valores extremos de mortalidade ou viabilidade, o teste de Tukey foi aplicado, utilizando-se o valor teórico da variância residual (Haddad \& Vendramim, 2000). No experimento referente ao efeito dos extratos utilizados antes do parasitismo sobre $T$. pretiosum (teste com chance de escolha), cada tratamento com extrato foi comparado com sua respectiva testemunha. Nesse caso utilizourse o teste "t" para contrastes, na comparação das médias.

Nas tabelas, os resultados foram representados pela média, acompanhada do respectivo erro padrão. 


\section{RESULTADOS E DISCUSSÃO}

\subsection{Testes preliminares}

\subsubsection{Determinação das concentrações adequadas dos extratos a serem utilizadas nos experimentos}

\subsubsection{Ação translaminar}

O extrato aquoso de sementes de nim aplicado na superfície adaxial dos folíolos do tomateiro provocou níveis elevados de mortalidade de Tuta absoluta. $\mathrm{Na}$ concentração de 5\%, nenhuma lagarta completou 0 desenvolvimento e, apesar da obtenção de algumas pupas no tratamento correspondente à concentração de 1\%, este não diferiu do anterior em relação à mortalidade larval. $\mathrm{O}$ extrato na menor concentração (0,5\%) provocou 57,0\% de mortalidade, sendo esse valor diferente dos observados na testemunha e nas demais concentrações (Tabela 1).

Pouco se conhece a respeito da ação translaminar de compostos presentes em extratos de nim. Esse efeito foi demonstrado por Verkerk et al. (1998) que estudou a ação de um inseticida à base de extratos de sementes dessa espécie sobre Myzus persicae (Sulzer) e Brevicoryne brassicae (L.). O produto foi aplicado na superfície adaxial de folhas de repolho, enquanto ninfas das duas espécies de pulgão foram confinadas em gaiolas fixadas na superfície abaxial das mesmas. Os autores registraram 100\% de mortalidade das ninfas 
após 96h da aplicação do produto, enquanto no tratamento-controle (folhas tratadas com água destilada) não foram observados insetos mortos.

Tabela 1. Mortalidade larval de T. absoluta em folíolos de tomateiro com a superfície adaxial tratada com extratos aquosos de sementes de nim. Temp.: 21,9 $\pm 10,94^{\circ} \mathrm{C}$; UR: 71,4 $\pm 33,89 \%$; fotoperíodo natural

\begin{tabular}{lc}
\hline \multicolumn{1}{c}{ Extratos } & Mortalidade (\%) \\
\hline Nim $5,0 \%$ & $100,0 \pm 0,00 \mathrm{a}$ \\
Nim $1,0 \%$ & $96,8 \pm 2,04 \mathrm{a}$ \\
Nim $0,5 \%$ & $57,0 \pm 6,33 \mathrm{~b}$ \\
Testemunha (água) & $6,0 \pm 3,20 \mathrm{c}$ \\
${ }^{1}$ Para efeito de análise estatística, os dados foram transformados em \\
arc sen $\sqrt{\mathrm{x} / \mathrm{N}}$. \\
${ }^{1}$ Médias seguidas de mesma letra não diferem entre si, pelo teste de Tukey \\
(P $\leq 0,05)$.
\end{tabular}

$\mathrm{Na}$ avaliação do desenvolvimento das minas nas folhas, aos sete dias, foi possível observar diferenças entre os tratamentos. Plantas que receberam extratos nas concentrações de 1 e $5 \%$ apresentaram grande porcentagem de minas pequenas, sendo que nenhuma mina grande foi verificada no tratamento com extrato a 5\%. No tratamento correspondente à aplicação do extrato na menor concentração $(0,5 \%)$, apesar de a maioria das minas encontradas ter sido classificada como médias ou pequenas, houve pequena porcentagem de minas grandes. No tratamento testemunha, por sua vez, todas as folhas infestadas apresentaram minas grandes (Figura 1). 


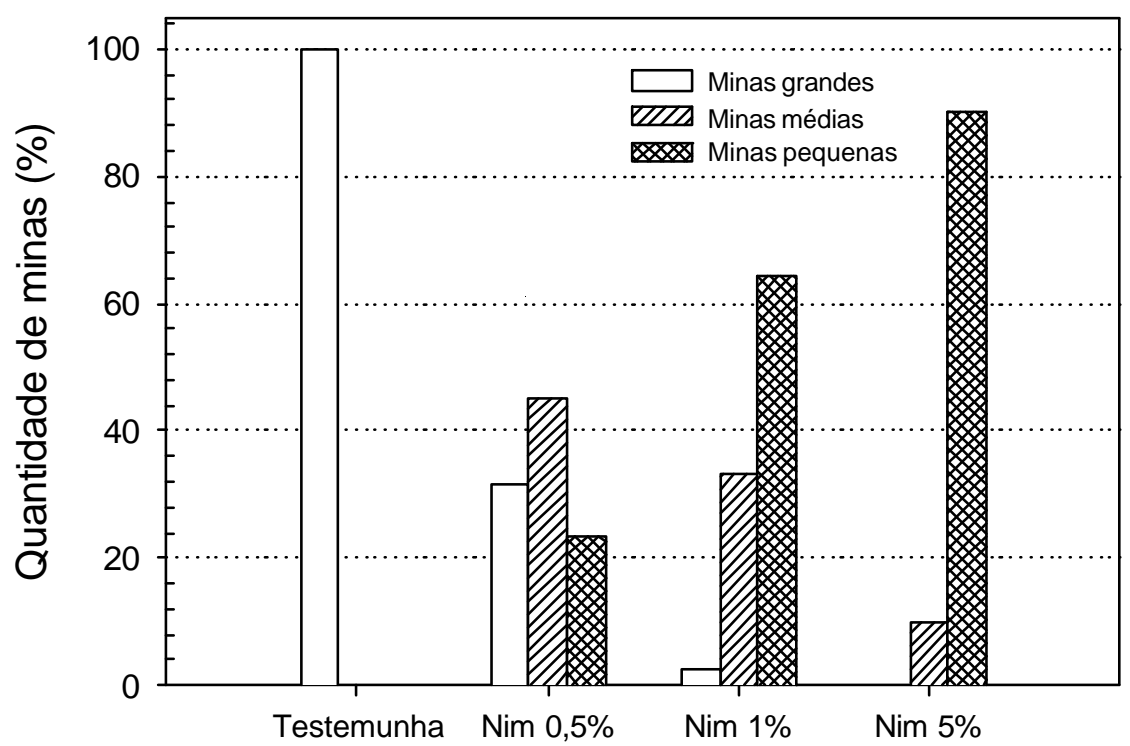

Figura 1 - Porcentagem de minas grandes, médias e pequenas provocadas por T. absoluta em folíolos de tomateiro com a superfície adaxial tratada com extratos aquosos de sementes de nim

\subsubsection{Ação sistêmica}

Quando extratos de sementes de nim foram aplicados no solo, também foi observado efeito negativo na sobrevivência das lagartas de T. absoluta. Nas concentrações de 10 e 5\% foram observados valores de mortalidade superiores a $98 \%$, sendo que esses tratamentos não diferiram entre si. Os tratamentos correspondentes às concentrações de 1 e 0,5\% provocaram 81,7 e 48,3\% de mortalidade, respectivamente. Esses valores, diferentes entre si, foram superiores àquele observado na testemunha (6,7\%) (Tabela 2).

Quanto ao desenvolvimento das minas aos sete dias, verificou-se, com extrato a 5 e 10\%, predominância de minas pequenas e médias em todos os folíolos das plantas tratadas. No tratamento a 1\%, houve predominância de minas de tamanho médio, enquanto que a $0,5 \%$ predominaram as minas médias e grandes em proporções semelhantes. Já na testemunha, $86,21 \%$ das minas 
encontradas foram classificadas como grandes (Figura 2).

Tabela 2. Mortalidade larval de T. absoluta em plantas de tomateiro cultivadas em solo tratado com extratos aquosos de sementes de nim. Temp.: $30,3 \pm 12,50^{\circ} \mathrm{C}$; UR: $64,1 \pm 34,24 \%$; fotoperíodo natural

\begin{tabular}{|c|}
\hline Mortalidade (\%) \\
\hline $100,0 \pm 0,00 a$ \\
\hline $98,3 \pm 1,67 a$ \\
\hline $81,7 \pm 4,86 b$ \\
\hline $48,3 \pm 3,12 c$ \\
\hline $6,7 \pm 1,67 d$ \\
\hline $\begin{array}{l}\text { Para efeito de análise estatística, os dados foram transformados em } \\
\text { arc sen } \sqrt{x / N} \text {. } \\
\text { Médias seguidas de mesma letra não diferem entre si, pelo teste de Tukey } \\
(P \leq 0,05) \text {. }\end{array}$ \\
\hline $\begin{array}{l}\text { O efeito sistêmico de compostos presentes em produtos àbase de nim } \\
\text { é bem documentado na literatura (Holmes \& Hassan, 1999; Larew et al., 1985; } \\
\text { Shivashankar et al., 2000; Sundaram et al., 1995). Considerando extratos } \\
\text { aquosos de sementes dessa espécie, esse efeito também foi registrado para } \\
\text { insetos mastigadores como é o caso das larvas de lepidópteros. Osman \& Port } \\
\text { (1990) demonstraram que extratos aquosos e o pó de sementes de nim, } \\
\text { aplicados diretamente no solo, provocaram redução significativa nos danos } \\
\text { provocados por Pieris brassicae (L.) sobre plantas de repolho, além de afetarem } \\
\text { negativamente a sobrevivência das lagartas. }\end{array}$ \\
\hline
\end{tabular}




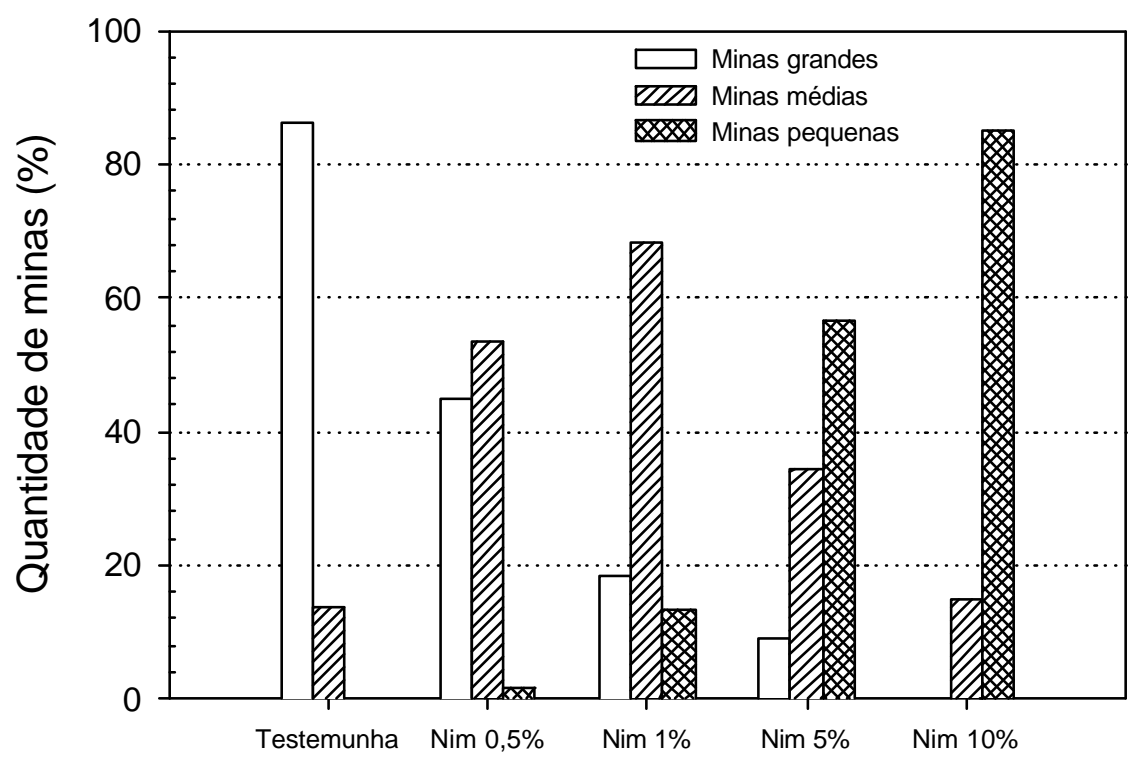

Figura 2 - Porcentagem de minas grandes, médias e pequenas provocadas por T. absoluta em folíolos de plantas de tomateiro cultivadas em solo tratado com extratos aquosos de sementes de nim

Rovesti \& Deseö (1991) também testaram a atividade sistêmica de extratos aquosos de sementes de nim sobre Leucoptera malifoliella Costa, um importante minador de folhas de macieira na Itália. $O$ teste envolveu a aplicação do extrato no solo e nas folhas mais baixas da planta. Foi verificado que, em ambas as formas de aplicação, os extratos foram absorvidos e translocados para a parte aérea. $O$ número de pupas nas plantas tratadas foi significativamente menor em relação ao verificado na testemunha, sendo que os efeitos mais drásticos dos tratamentos foram verificados no terço inferior das plantas.

\subsubsection{Ação de contato}

Nesse experimento, ficou demonstrado que o extrato aquoso de sementes de nim apresenta ação de contato sobre lagartas de $T$. absoluta. $O$ 
efeito mais acentuado foi verificado quando se utilizou o extrato na concentração de $10 \%$, onde a mortalidade chegou a cerca de $95 \%$. Os valores observados nas duas concentrações menores (75,2\% a 5\% e 52,4\% a $1 \%$ ) foram superiores àquele constatado no testemunha $(2,8 \%)$, onde foi feita aplicação tópica de água destilada sobre as lagartas (Tabela 3).

Tabela 3. Mortalidade larval de T. absoluta tratada topicamente, no segundo instar, com extratos aquosos de sementes de nim. Temp.: $25 \pm 2^{\circ} \mathrm{C}$; UR: $70 \pm 10 \%$; fotofase: $12 \mathrm{~h}$

\begin{tabular}{|c|c|}
\hline Extratos & Mortalidade (\%) \\
\hline $\operatorname{Nim} 10 \%$ & $95,4 \pm 1,90 \quad a$ \\
\hline $\operatorname{Nim} 5 \%$ & $75,2 \pm 10,05 a b$ \\
\hline $\operatorname{Nim} 1 \%$ & $52,4 \pm 4,84 \quad b$ \\
\hline Testemunha & $2,8 \pm 1,69 c$ \\
\hline
\end{tabular}

O efeito de contato de extratos de nim já havia sido demonstrado para algumas espécies de insetos. Abraham \& Ambika (1979) verificaram que extratos acetônicos de folhas e sementes dessa meliácea, aplicados topicamente sobre o abdome de ninfas de terceiro, quarto e quinto ínstar de Dysdercus cingulatus Fabr., afetaram de forma negativa o desenvolvimento e reprodução desses insetos.

Esse efeito também foi registrado em relação a Spodoptera exempta Walker por Tanzubil \& McCaffery (1990). Os autores utilizaram lagartas de quarto ínstar, as quais foram tratadas por imersão em extratos aquosos de sementes de nim a 5 e 10\%. Foi observado que o extrato na concentração de 10\% inibiu completamente a alimentação, provocando $100 \%$ de mortalidade larval, após 
cinco dias da aplicação.

\subsubsection{Avaliação da atividade de extratos orgânicos de T. pallida sobre $T$. absoluta}

No primeiro experimento, o extrato aquoso de sementes de nim provocou alta mortalidade de lagartas de $T$. absoluta $(91,5 \%)$, sendo considerado o tratamento mais eficiente. Entre os extratos de folhas de $T$. pallida, incluindo o aquoso, os valores de mortalidade variaram de 34,9 e $49,9 \%$, não tendo sido observadas diferenças significativas entre os mesmos. Estes, por sua vez, diferiram das duas testemunhas, as quais se comportaram de modo semelhante (Tabela 4).

Tabela 4. Mortalidade larval de T. absoluta em folíolos de tomateiro tratados com extratos aquosos e orgânicos de folhas de T. pallida e extrato aquoso de sementes de nim a $5 \%$ (Experimento 1). Temp.: $24,1 \pm$ $1,48^{\circ} \mathrm{C}$; UR: $62,5 \pm 8,89 \%$; fotofase: $12 \mathrm{~h}$

\begin{tabular}{|c|c|}
\hline Extratos & Mortalidade (\%) \\
\hline Sementes de nim (aquoso) & $91,5 \pm 4,57 a$ \\
\hline Folhas de T. pallida (clorofórmico) & $49,9 \pm 4,76 b$ \\
\hline Folhas de T. pallida (aquoso) & $49,5 \pm 7,02 b$ \\
\hline Folhas de T.pallida (etanólico) & $45,1 \pm 8,41 b$ \\
\hline Folhas de $T$. pallida (hexânico) & $41,4 \pm 4,85 b$ \\
\hline Folhas de T. pallida (metanólico) & $34,9 \pm 5,28 b$ \\
\hline Testemunha (acetona) & $7,1 \pm 1,81 \mathrm{c}$ \\
\hline Testemunha (água) & $3,5 \pm 2,14 \mathrm{c}$ \\
\hline
\end{tabular}


No segundo experimento, em que se excluiu o extrato de sementes de nim, foi observada melhor discriminação entre os extratos de folhas de $T$. pallida. Nesse caso, o extrato clorofórmico, que provocou $73,8 \%$ de mortalidade larval, apesar de não diferir significativamente dos extratos etanólico (60\%) e metanólico $(58,5 \%)$, foi mais eficiente que os extratos aquoso $(46,9 \%)$ e hexânico (26,4\%). Dentre estes, apenas a mortalidade com o extrato hexânico não diferiu da testemunha (8,5\%), evidenciando-se, também nesse experimento, que os extratos de T. pallida afetam as lagartas de T. absoluta, com destaque para o extrato clorofórmico que mostrou-se assim o mais efetivo. (Tabela 5).

Tabela 5. Mortalidade larval de T. absoluta em folíolos de tomateiro tratados com extratos aquosos e orgânicos de folhas de T. pallida a 5\% (Experimento 2). Temp.: 24,8 $\pm 1,43^{\circ} \mathrm{C}$; UR: 63,1 \pm 8,58\%; fotofase: $12 \mathrm{~h}$

\begin{tabular}{|c|c|}
\hline Extratos & Mortalidade (\%) \\
\hline Folhas de T. pallida(clorofórmico) & $73,8 \pm 7,20 a$ \\
\hline Folhas de T. pallida(etanólico) & $60,0 \pm 7,32 \mathrm{ab}$ \\
\hline Folhas de T. pallida(metanólico) & $58,5 \pm 5,51 a b$ \\
\hline Folhas de T. pallida(aquoso) & $46,9 \pm 5,11 b c$ \\
\hline Folhas de T. pallida(hexânico) & $26,4 \pm 4,31 \mathrm{~cd}$ \\
\hline Testemunha (água) & $8,5 \pm 2,72 \mathrm{~d}$ \\
\hline
\end{tabular}

Jaglan et al. (1997) também destacaram a eficiência do clorofórmio em extrair compostos inseticidas de sementes e folhas de $A$. indica. A atividade de extratos orgânicos dessa espécie foi avaliada sobre Helicoverpa armigera 
(Hübner), utilizando para extração, o metanol e uma mistura (9:1) de clorofórmio e metanol. Nesse teste foi demonstrado que o extrato obtido com a mistura de solventes foi mais eficiente sobre os insetos do que o extrato obtido a partir do metanol puro. Os autores atribuíram esse resultado à diferença de polaridade existente entre os dois solventes. Assim, o metanol, por ser altamente polar, teria extraído muitas substâncias polares inativas para o inseto, como açúcares, taninos e outras, levando à diluição das substâncias ativas no extrato. Por outro lado, como o clorofórmio é um solvente mais apolar, a mistura apresentaria uma faixa de polaridade mais ampla, podendo extrair mais substâncias ativas do que inativas. Isso poderia explicar o fato de os extratos obtidos a partir da mistura clorofórmio + etanol terem se mostrado mais ativos sobre o inseto mesmo em concentrações mais baixas.

Diversos autores têm destacado uma relação direta entre a polaridade do solvente utilizado na extração e a atividade de extratos de meliáceas sobre insetos (Ascher et al., 1984; Mikolajczak \& Reed, 1987 e Mikolajczak et al., 1989). No presente trabalho, entretanto, isso não foi observado. O extrato obtido a partir do clorofórmio (um dos extratores com menor polaridade) se mostrou tão eficiente quanto aqueles obtidos com etanol e metanol (com polaridade mais alta). McMillian et al. (1969), testando extratos aquoso, hexânico, metil alcoólico e clorofórmico de $M$. azedarach em relação a Spodoptera frugiperda (J.E. Smith), também encontraram maior atividade com o extrato clorofórmico (menos polar que os extratos aquoso e metil alcoólico). Silva (1990), avaliando plantas de diversas famílias botânicas, cujos extratos foram obtidos com solventes de diferentes polaridades, também não encontrou relação entre polaridade e atividade tóxica sobre Ceratitis capitata (Wied.) e Ascia monuste orseis (Godart). Roel et al. (2000a), estudando o efeito de extratos orgânicos de folhas e ramos de $T$. pallida sobre $S$. frugiperda observaram que o extrato com menor polaridade (acetônico) foi mais ativo que o mais polar (metanólico), evidenciando que nem sempre é possível selecionar 
um extrato orgânico com maior atividade em relação a uma determinada espécie de inseto, apenas com base na polaridade.

Comparando-se os dois experimentos realizados, verificourse uma variação entre os resultados obtidos para o mesmo extrato em relação à mortalidade larval de T. absoluta. Esse fato se deve provavelmente à variação na idade das lagartas utilizadas. No primeiro teste, em razão da disponibilidade de insetos, foram utilizadas lagartas com até três dias de idade, enquanto no segundo, selecionaram-se apenas aquelas recém-eclodidas. Diferenças na resposta à aplicação de extratos vegetais em função da idade dos insetos têm sido relatadas. Jaglan et al. (1997) verificaram que larvas recém-eclodidas de $H$. armigera são mais sensíveis a extratos orgânicos de folhas e sementes de nim do que larvas em estágios mais avançados de desenvolvimento. Em estudos utilizando extrato acetato de etila de folhas e ramos de T. pallida e a lagarta-do-cartucho (S. frugiperda), Roel et al. (2000b) demonstraram que lagartas alimentadas desde a eclosão com folhas de milho tratadas com extrato foram mais afetadas do que as que receberam esse tratamento a partir dos 10 dias de idade. Essa resposta, entretanto, parece variar em função do composto inseticida envolvido, já que Martinez \& van Endem (2001) observaram o inverso. Assim, comparando a ação da azadiractina sobre lagartas pequenas (terceiro ínstar) e de último ínstar (prestes a pupar) de S. littoralis (Boisd.), os referidos autores observaram 75 e 95\% de mortalidade para lagartas grandes alimentadas com dieta artificial contendo este composto em concentrações de 0,3 e 0,6 ppm, respectivamente, enquanto para as menores, a mortalidade observada foi de $5 \%$ nas duas concentrações.

\subsubsection{Considerações gerais}

Com base nos resultados obtidos nos testes preliminares, verificou-se que os extratos aquosos de sementes de nim apresentaram alta atividade sobre T. absoluta, reforçando os resultados obtidos por Brunherotto (2000) e Trindade 
et al. (2000). Nesse trabalho, ficou demonstrado que os extratos provocam elevada mortalidade sobre larvas desses insetos, independentemente da forma em que os mesmos são aplicados.

Dentre os modos de ação estudados, o efeito translaminar foi o mais evidente, uma vez que menores concentrações dos extratos foram capazes de provocar os mais altos valores de mortalidade larval. Provavelmente, esses extratos contenham substâncias ativas capazes de penetrar a epiderme foliar do tomateiro, atingindo as larvas que se alimentam no mesofilo, condição considerada essencial no controle de insetos minadores (Stein \& Parrela, 1985; Webb et al., 1983).

No teste envolvendo o efeito sistêmico, foi possível verificar que compostos inseticidas presentes nos extratos são capazes de atingir o inseto na parte aérea da planta, mesmo quando aplicados no solo. Esse efeito, já demonstrado por diversos autores, é bastante desejável para produtos à base de nim, uma vez que os compostos ativos encontrados nos extratos dessa planta são altamente sensíveis à radiação (Osman \& Port, 1990; Schmutterer, 1990).

$\mathrm{Na}$ avaliação do efeito tópico, observou-se a necessidade de concentrações mais altas do extrato para obtenção de valores de mortalidade comparáveis aos observados nos outros testes. Isso pode ser um indicativo de que os compostos inseticidas presentes no extrato de sementes de nim sejam mais eficientes quando ingeridos pelo inseto. A superioridade da ação de ingestão da azadiractina (principal composto com ação inseticida em extratos de nim) foi constatada para $S$. littoralis ao se verificar que a $\mathrm{CL}_{50}$ obtida por ingestão de dieta durante dois dias mostrou-se cerca de 200 vezes inferior à obtida por pulverização (Martinez, 2002). Em estudos com S. frugiperda, Viana et al. (2000) verificaram mortalidade de $32,2 \%$ quando as lagartas foram pulverizadas com extrato de folhas de nim a $1 \%$. Esse valor foi inferior ao obtido quando as lagartas foram alimentadas com folhas de milho tratadas com 0 mesmo extrato, sendo que nesse caso, a mortalidade foi de $87,3 \%$. 
Durante as avaliações, os sintomas observados nas lagartas foram semelhantes em todos os testes. Esses sintomas envolveram redução na alimentação, atraso no desenvolvimento e morte do inseto durante a troca de tegumento, o que caracteriza os efeitos fagodeterrente e regulador de crescimento atribuídos a extratos de $A$. indica (Govindachari et al., 2000; Mordue (Luntz) \& Blackwell, 1993; Mordue (Luntz) et al., 1998; Schumutterer, 1990; Sclar, 2001).

Em relação aos extratos orgânicos de folhas de $T$. pallida, verificou-se que o clorofórmico apresentou melhores resultados sobre $T$. absoluta. A mortalidade larval observada com o uso desse extrato superou até mesmo aquela provocada pelo extrato aquoso dessa espécie, o qual possui reconhecida atividade sobre a praga (Thomazini et al., 2000).

Para determinação do modo de ação de substâncias presentes em extratos de T. pallida em comparação com o de sementes de nim, foram selecionadas as concentrações de 0,$5 ; 1$ e $5 \%$ para serem utilizadas nos ensaios envolvendo os efeitos translaminar, sistêmico e de contato, respectivamente. Uma vez que nessas concentrações o extrato aquoso de nim apresentou resultados intermediários sobre $T$. absoluta, as mesmas foram selecionadas para que houvesse possibilidade de se detectar, dentre os extratos de folhas de T. pallida, aqueles que porventura apresentassem maior eficiência que o extrato de sementes de nim sobre a praga.

Além das concentrações mais adequadas, os testes preliminares indicaram o extrato clorofórmico de folhas de $T$. pallida como sendo o mais eficiente, dentre os orgânicos testados, sobre a traça-do-tomateiro. Sendo assim, esse extrato foi selecionado para compor os testes de bioatividade de extratos de meliáceas sobre o inseto em questão. 


\subsection{Determinação do modo de ação de extratos de folhas de T. pallida sobre T. absoluta}

\subsubsection{Ação translaminar}

Quando se utilizou a concentração de $0,5 \%$, como havia sido determinado no teste preliminar, o extrato de sementes de nim provocou $100 \%$ de mortalidade larval, confirmando a sua capacidade de atingir o inseto que se alimenta entre as epidermes foliares. Dentre os extratos de folhas de T. pallida, somente o clorofórmico, em que a viabilidade foi $85,2 \%$, diferiu da testemunha (água) (98,7\%). O extrato aquoso de folhas dessa espécie proporcionou viabilidade de $91,6 \%$, valor este semelhante aos observados nas duas testemunhas, os quais não diferiram entre si. $O$ extrato aquoso de folhas de $T$. pallida provocou alongamento da fase larval de $T$. absoluta (17,6 dias) quando comparado com a testemunha (água) (15,8 dias). Por outro lado, esse parâmetro não foi afetado pelo extrato clorofórmico. Não foi possível avaliar a duração do período larval em relação ao extrato de sementes de nim, já que nenhuma lagarta completou o desenvolvimento nesse tratamento (Tabela 6 ).

No que se refere à viabilidade e à duração da fase pupal, não foram observadas diferenças entre os tratamentos (Tabela 7). Os valores de viabilidade dessa fase variaram entre 82,0 e 93,4\%, sendo que a duração ficou compreendida entre 8,7 e 9,2 dias, à semelhança dos resultados obtidos por outros autores (aproximadamente 8 dias) em temperaturas próximas de $25^{\circ} \mathrm{C}$ (Giustolin \& Vendramim, 1996; Paulo, 1986; Razuri \& Vargas, 1975; Vargas, 1970). 
Tabela 6. Viabilidade e duração da fase larval de T. absoluta em folíolos de tomateiro com a superfície adaxial tratada com extratos de meliáceas (0,5\%). Temp.: $25,2 \pm 11,39^{\circ} \mathrm{C}$; UR: $59,6 \pm 33,19 \%$; fotoperíodo natural

\begin{tabular}{lcc}
\hline \multicolumn{1}{c}{ Extratos } & Viabilidade (\%) $^{1}$ & Duração (dias) $^{1}$ \\
\hline Testemunha (água) & $98,7 \pm 1,33 \mathrm{a}$ & $15,8 \pm 0,11 \mathrm{a}$ \\
Testemunha (acetona) & $98,0 \pm 2,00 \mathrm{ab}$ & $16,3 \pm 0,18 \mathrm{ab}$ \\
Folhas de $T$. pallida(aquoso) & $91,6 \pm 3,61 \mathrm{ab}$ & $17,6 \pm 0,60 \mathrm{~b}$ \\
Folhas de $T$. pallida(clorofórmico) & $85,2 \pm 5,33 \mathrm{~b}$ & $16,2 \pm 0,30 \mathrm{ab}$ \\
Sementes de nim (aquoso) & $0,0 \pm 0,00 \mathrm{c}$ & -
\end{tabular}

Para efeito de análise estatística, os dados de viabilidade foram transformados em $\operatorname{arcsen} \sqrt{\mathrm{x} / \mathrm{N}}$.

${ }^{1}$ Médias seguidas de mesma letra não diferem entre si, pelo teste de Tukey $(P \leq 0,05)$.

Tabela 7. Viabilidade e duração da fase pupal de T. absoluta em folíolos de tomateiro com a superfície adaxial tratada com extratos de meliáceas (0,5\%). Temp.: $25,03 \pm 1,39^{\circ} \mathrm{C}$; UR: $65,02 \pm 9,48 \%$; fotofase: $12 \mathrm{~h}$

\begin{tabular}{lcc}
\hline \multicolumn{1}{c}{ Extratos } & Viabilidade (\%) $^{1}$ & Duração (dias) $^{1}$ \\
\hline Testemunha (água) & $90,1 \pm 6,13$ & $9,1 \pm 0,17$ \\
Testemunha (acetona) & $90,6 \pm 4,02$ & $8,7 \pm 0,30$ \\
Folhas de $T$. pallida (aquoso) & $93,4 \pm 2,90$ & $9,2 \pm 0,11$ \\
Folhas de $T$. pallida (clorofórmico) & $82,0 \pm 6,20$ & $9,1 \pm 0,08$ \\
\hline
\end{tabular}

Médias, nas colunas, não diferem entre si, pelo teste de Tukey $(\mathrm{P} \leq 0,05)$. 
O peso de pupas não foi afetado pelos tratamentos, sendo que seus valores variaram de 2,5 a 2,9 mg para machos e 3,3 a 3,9 mg para fêmeas (Figura 3).

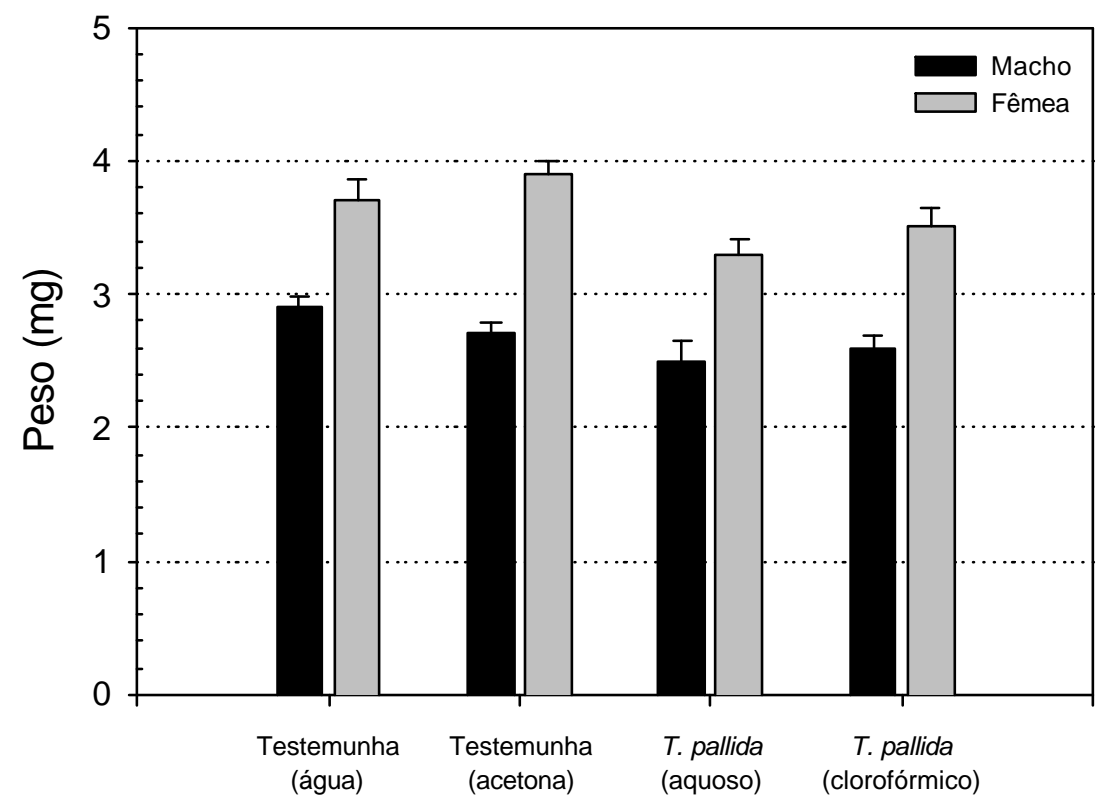

Figura 3 - Peso de pupas de T. absoluta em folíolos de tomateiro com a superfície adaxial tratada com extratos de folhas de T. pallida (0,5\%). Temp.: $24,35 \pm 1,48^{\circ} \mathrm{C}$; UR: $68,02 \pm 9,18 \%$; fotofase: $12 \mathrm{~h}$

Quando se aumentou a concentração dos extratos de folhas de $T$. pallida para $5 \%$, verificourse efeito dos extratos aquoso e clorofórmico, os quais proporcionaram viabilidades larvais de 65,4 e 69,9\%, respectivamente, diferindo da registrada na testemunha $(97,1 \%)$. Apesar da menor concentração utilizada $(0,5 \%)$, o extrato de sementes de nim, ainda assim, reduziu drasticamente a viabilidade larval do inseto $(8,57 \%)$, diferindo das obtidas nos demais tratamentos.

$\mathrm{Na}$ concentração de 5\%, o extrato aquoso de T. pallida também alongou o período larval de $T$. absoluta (15,0 dias) em relação à testemunha (13,3 dias), o que não foi observado com o extrato clorofórmico. Como no teste 
anterior, esse parâmetro não foi avaliado para o tratamento com extrato de nim, em razão do número reduzido de pupas obtido nesse tratamento (Tabela 8).

Como no tratamento correspondente à testemunha água + acetona os resultados foram semelhantes aos obtidos no tratamento contendo apenas água, o tratamento contendo acetona foi excluído do segundo teste.

Tabela 8. Viabilidade e duração da fase larval de T. absoluta em folíolos de tomateiro com a superfície adaxial tratada com extratos de meliáceas. Temp.: 26,6 \pm 10,39² C; UR: 59,7 \pm 33,70\%; fotoperíodo natural

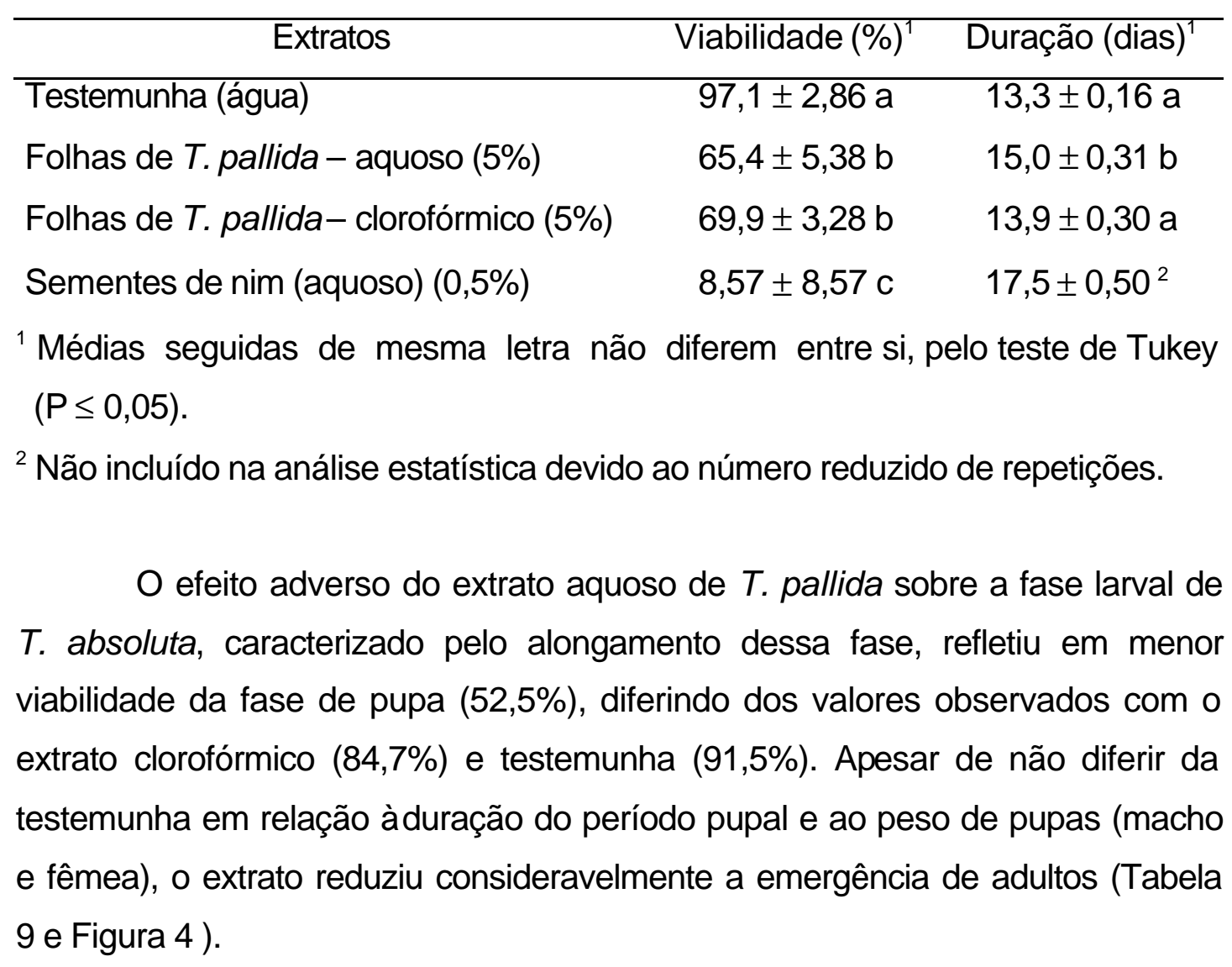


Tabela 9. Viabilidade e duração da fase pupal de T. absoluta em folíolos de tomateiro com a superfície adaxial tratada com extratos de $T$. pallida. Temp.: $24,35 \pm 1,48^{\circ} \mathrm{C}$; UR: $68,02 \pm 9,18 \%$; fotofase: $12 \mathrm{~h}$

\begin{tabular}{|c|c|c|}
\hline Extratos & Viabilidade (\%) $^{\top}$ & Duração (dias)² \\
\hline Testemunha (água) & $91,5 \pm 5,89 a$ & $7,9 \pm 0,23$ \\
\hline Folhas de T. pallida - aquoso (5\%) & $52,5 \pm 7,86 b$ & $8,4 \pm 0,39$ \\
\hline Folhas de T. pallida- clorofórmico (5\%) & $84,7 \pm 7,42 a$ & $8,1 \pm 0,06$ \\
\hline
\end{tabular}

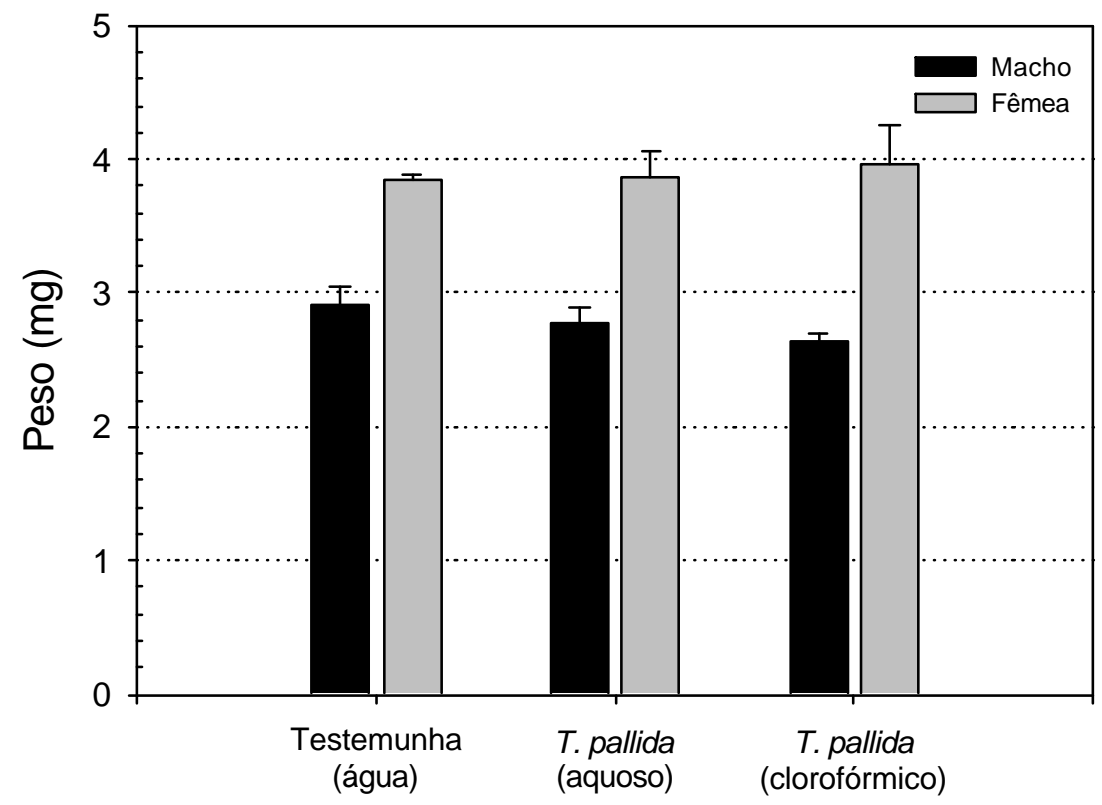

Figura 4 - Peso de pupas de T. absoluta em folíolos de tomateiro com a superfície adaxial tratada com extratos de folhas de T. pallida (5\%). Temp.: $24,35 \pm 1,48^{\circ} \mathrm{C}$; UR: $68,02 \pm 9,18 \%$; fotofase: $12 \mathrm{~h}$ 
O efeito translaminar dos extratos de folhas de T. pallida começou a se tornar evidente com o aumento da concentração dos mesmos. Esse efeito, entretanto é pouco expressivo, quando comparado ao efeito do extrato de semente de nim, o qual se mostrou ativo mesmo numa concentração 10 vezes menor do que os da primeira espécie.

\subsubsection{Ação sistêmica}

Quando os extratos foram aplicados no solo na concentração de 1\%, não foi observada diferença entre os tratamentos correspondentes aos extratos de folhas de $T$. pallida e as testemunhas (água e água + acetona) quanto à viabilidade larval, a qual foi superior a $90 \%$ em todos os casos. Por outro lado, o extrato de nim provocou mais de $80 \%$ de mortalidade das lagartas, sendo que as pupas obtidas nesse tratamento apresentaram-se deformadas, não havendo emergência de adultos.

Assim como a viabilidade, a duração da fase larval de T. absoluta (14,7 a 15,3 dias) não foi afetada pelos extratos de T. pallida (Tabela 10). A duração da fase pupal não diferiu entre os tratamentos com extratos de $T$. pallida (1\%), o mesmo ocorrendo com a viabilidade dessa fase, tendo sido registrados valores variáveis entre 8,2 e 8,8 dias e 81,8 e 95,2\%, respectivamente (Tabela 11).

Ainda em relação àfase de pupa, observou-se variação de 2,9 a 3,2 g e de 3,5 a 4,0 g no peso de machos e fêmeas, respectivamente, sendo que para esse parâmetro não foram observadas diferenças significativas entre os tratamentos (Figura 5). 
Tabela 10. Viabilidade e duração da fase larval de T. absoluta em plantas de tomateiro cultivadas em solo tratado com extratos de meliáceas (1\%). Temp.: $26,26 \pm 11,30^{\circ} \mathrm{C}$; UR: $59,65 \pm 33,40 \%$; fotoperíodo natural

\begin{tabular}{|c|c|c|}
\hline Extratos & Viabilidade (\%) $^{\top}$ & Duração (dias)² \\
\hline Testemunha (água) & $97,9 \pm 1,86 a$ & $14,7 \pm 0,27$ \\
\hline Testemunha (acetona) & $97,7 \pm 2,03 \mathrm{a}$ & $14,7 \pm 0,25$ \\
\hline Folhas de T. pallida(aquoso) & $90,2 \pm 3,66 \mathrm{a}$ & $14,9 \pm 0,17$ \\
\hline Folhas de T. pallida(clorofórmico) & $97,7 \pm 2,03 \mathrm{a}$ & $15,3 \pm 0,34$ \\
\hline Sementes de nim (aquoso) & $12,2 \pm 6,72 b$ & $16,7 \pm 0,35^{3}$ \\
\hline \multicolumn{3}{|c|}{$\begin{array}{l}\text { 'Médias seguidas de mesma letra não diferem entre si, pelo teste de Tuke } \\
(P \leq 0,05) \text {. }\end{array}$} \\
\hline
\end{tabular}

Tabela 11. Viabilidade e duração da fase pupal de T. absoluta em plantas de tomateiro cultivadas em solo tratado com extratos de $T$. pallida (1\%). Temp.: $25,15 \pm 2,32^{\circ} \mathrm{C}$; UR: $70,02 \pm 9,30 \%$; fotofase: $12 \mathrm{~h}$

\begin{tabular}{lcc}
\hline \multicolumn{1}{c}{ Extratos } & Viabilidade (\%) $^{1}$ & Duração (dias) $^{1}$ \\
\hline Testemunha (água) & $91,6 \pm 2,55$ & $8,8 \pm 0,24$ \\
Testemunha (acetona) & $95,2 \pm 2,47$ & $8,5 \pm 0,22$ \\
Folhas de T. pallida(aquoso) & $86,8 \pm 1,08$ & $8,4 \pm 0,19$ \\
Folhas de T. pallida(clorofórmico) & $81,8 \pm 5,80$ & $8,2 \pm 0,13$ \\
\hline
\end{tabular}

Médias, nas colunas, não diferem entre si, pelo teste de Tukey $(\mathrm{P} \leq 0,05)$. 


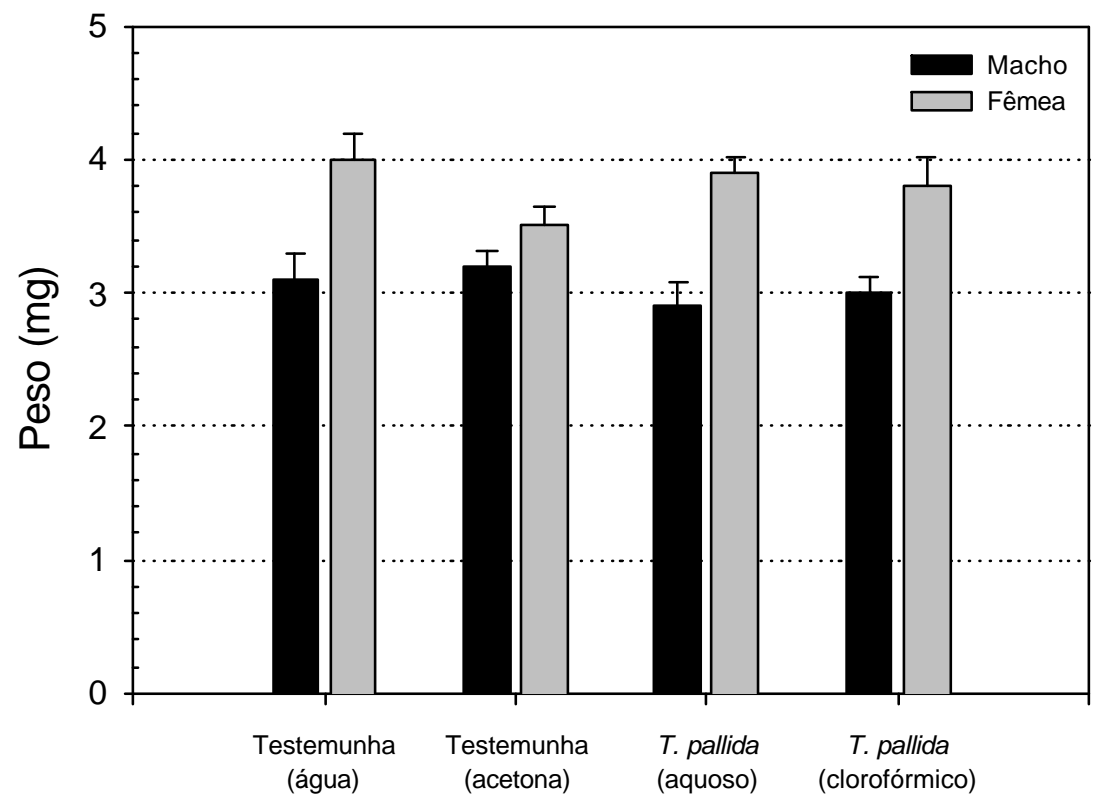

Figura 5 - Peso de pupas de T. absoluta em plantas de tomateiro cultivadas em solo tratado com extratos de folhas de T. pallida (1\%). Temp.: $25,05 \pm 1,48^{\circ} \mathrm{C}$; UR: $70,10 \pm 8,35 \%$; fotofase: $12 \mathrm{~h}$

O aumento na concentração dos extratos de T. pallida de 1 para $5 \%$ não alterou o comportamento dos mesmos na comparação com a testemunha no que diz respeito à viabilidade da fase larval. Os valores de viabilidade observados na testemunha $(93,3 \%)$, extrato clorofórmico $(91,3 \%)$ e extrato aquoso $(81,9 \%)$ foram semelhantes entre si, diferindo apenas do tratamento correspondente ao extrato de sementes de nim que mesmo na concentração de $1 \%$ reduziu a viabilidade larval para 5,48\%. Apesar de não afetarem a sobrevivência larval, os extratos de $T$. pallida na concentração de $5 \%$ provocaram alongamento dessa fase. Os valores observados nos tratamentos referentes ao extrato clorofórmico (14,8 dias) e aquoso (17,4 dias) foram superiores ao registrado na testemunha (11,9 dias) (Tabela 12$)$. 
Tabela 12. Viabilidade e duração da fase larval de $T$. absoluta em plantas de tomateiro cultivadas em solo tratado com extratos de meliáceas. Temp.: $27,29 \pm 9,88^{\circ} \mathrm{C}$; UR: $60,15 \pm 33,19 \%$; fotoperíodo natural

\begin{tabular}{lcc}
\hline \multicolumn{1}{c}{ Extratos } & Viabilidade (\%) $^{1}$ & Duração (dias) $^{1}$ \\
\hline Testemunha (água) & $93,3 \pm 2,86 \mathrm{a}$ & $11,9 \pm 0,29 \mathrm{a}$ \\
Folhas de T. pallida- clorofórmico (5\%) & $91,3 \pm 2,60 \mathrm{a}$ & $14,8 \pm 0,30 \mathrm{~b}$ \\
Folhas de T. pallida - aquoso (5\%) & $81,9 \pm 8,98 \mathrm{a}$ & $17,4 \pm 0,93 \mathrm{c}$ \\
Sementes de nim (aquoso) (1\%) & $5,48 \pm 2,25 \mathrm{~b}$ & $17,5 \pm 1,50^{2}$
\end{tabular}

Médias seguidas de mesma letra não diferem entre si, pelo teste de Tukey $(P \leq 0,05)$.

${ }^{2}$ Não incluído na análise estatística devido ao número reduzido de repetições.

O extrato aquoso de folhas de T. pallida, a $5 \%$, também afetou a viabilidade pupal que apresentou menor valor $(59,3 \%)$ que o registrado na testemunha $(86,5 \%)$. Por outro lado, não foram observados efeitos dos extratos na duração da fase pupal (Tabela 13) e peso de pupas (machos e fêmeas) (Figura 6).

Os resultados indicam que o efeito sistêmico de extratos de folhas de $T$. pallida pode se manifestar em concentrações maiores do que as utilizadas nesses experimentos, uma vez que o aumento na concentração de 1 para $5 \%$ resultou em alongamento da fase larval. Provavelmente, compostos inseticidas com capacidade de translocação na planta estejam em quantidades reduzidas em folhas de $T$. pallida, exigindo assim uma maior concentração dos extratos para que sua ação possa se manifestar. 
Tabela 13. Viabilidade e duração da fase pupal de $T$. absoluta em plantas de tomateiro cultivadas em solo tratado com extratos de T. pallida. Temp.: $25,05 \pm 1,48^{\circ} \mathrm{C}$; UR: $70,10 \pm 8,35 \%$; fotofase: $12 \mathrm{~h}$

\begin{tabular}{lcc}
\hline \multicolumn{1}{c}{ Extratos } & Viabilidade (\%) & Duração (dias) \\
\hline Testemunha (água) & $86,5 \pm 4,64 \mathrm{a}$ & $7,9 \pm 0,23$ \\
Folhas de T. pallida- clorofórmico (5\%) & $74,1 \pm 3,15 \mathrm{ab}$ & $8,1 \pm 0,06$ \\
Folhas de T. pallida - aquoso (5\%) & $59,3 \pm 6,09 \mathrm{~b}$ & $8,4 \pm 0,39$ \\
\hline & \\
\hline & Médias seguidas de mesma letra não diferem entre si, pelo teste de Tukey \\
(P $\leq 0,05) ;$ & \\
${ }^{2}$ Médias, nas colunas, não diferem entre si, pelo teste de Tukey $(\mathrm{P} \leq 0,05)$.
\end{tabular}

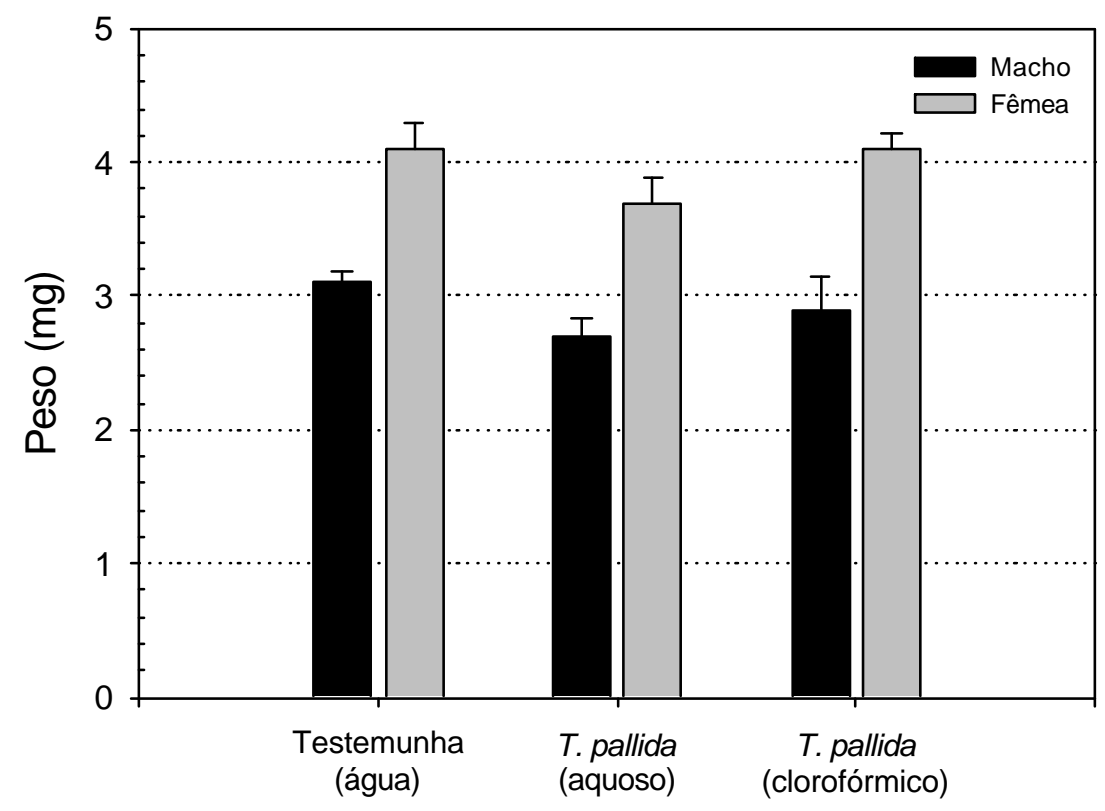

Figura 6 - Peso de pupas de T. absoluta em plantas de tomateiro cultivadas em solo tratado com extratos de folhas de T. pallida (5\%). Temp.: $25,05 \pm 1,48^{\circ} \mathrm{C}$; UR: $70,10 \pm 8,35 \%$; fotofase: $12 \mathrm{~h}$ 


\subsubsection{Ação de contato}

No primeiro teste, referente à ação de contato, quando se utilizaram os extratos na concentração de $5 \%$, foi observada baixa viabilidade $(22,5 \%)$ das lagartas de $T$. absoluta tratadas com extrato de sementes de nim. Em relação aos dois extratos de $T$. pallida, apenas o clorofórmico reduziu a viabilidade (61,5\%), diferindo do extrato aquoso $(81,6 \%)$ e das testemunhas $(89,3$ e $91,0 \%)$. O extrato de nim também afetou significativamente o desenvolvimento da traça-do-tomateiro, alongando a fase larval. Quando o inseto foi tratado topicamente com o referido extrato, a duração dessa fase foi de 17,5 dias, enquanto no extrato clorofórmico de T. pallida e nas testemunhas, esse período foi significativamente inferior, variando de 15,6 a 16,0 dias; no extrato aquoso de T. pallida, obteve-se valor intermediário (Tabela 14).

Tabela 14. Viabilidade e duração da fase larval de $T$. absoluta tratada topicamente no segundo ínstar larval com extratos de meliáceas (5\%). Temp.: $25,23 \pm 2,08^{\circ} \mathrm{C}$; UR: $69,81 \pm 9,80 \%$; fotofase: $12 \mathrm{~h}$

\begin{tabular}{|c|c|c|}
\hline Extratos & Viabilidade (\%) ${ }^{\top}$ & Duração (dias) $^{1}$ \\
\hline Testemunha (água) & $91,0 \pm 3,91 \mathrm{a}$ & $16,0 \pm 0,10 \mathrm{a}$ \\
\hline Testemunha (acetona) & $89,3 \pm 3,29 a$ & $15,6 \pm 0,23 a$ \\
\hline Folhas de T. pallida (aquoso) & $81,6 \pm 1,95 a$ & $16,4 \pm 0,18 a b$ \\
\hline Folhas de T. pallida (clorofórmico) & $61,5 \pm 7,71 b$ & $15,9 \pm 0,42 a$ \\
\hline Sementes de nim (aquoso) & $22,5 \pm 2,37 c$ & $17,5 \pm 0,36 b$ \\
\hline
\end{tabular}

De acordo com Martinez (2002), alterações no desenvolvimento dos insetos, como redução do crescimento e prolongamento do período larval, 
podem ser atribuídas à ação neuro-hormonal da azadiractina, principal composto inseticida presente em extratos de nim.

Todas as pupas obtidas a partir de lagartas tratadas com extrato de nim se apresentaram deformadas. Assim, esse tratamento não foi incluído na avaliação da viabilidade e duração da fase pupal. Esses parâmetros, entretanto, não foram afetados pelos extratos de folhas de $T$. pallida, sendo que a viabilidade da fase de pupa variou de 68,6 a 85,6\% e a duração de 9,8 a 10,2 dias, considerando-se os quatro tratamentos (Tabela 15).

Tabela 15. Viabilidade e duração da fase pupal de T. absoluta tratada topicamente no segundo ínstar larval com extratos de T. pallida (5\%). Temp.: $25,18 \pm 2,10^{\circ} \mathrm{C}$; UR: $69,55 \pm 10,80 \%$; fotofase: $12 \mathrm{~h}$

\begin{tabular}{lcc}
\hline \multicolumn{1}{c}{ Extratos } & Viabilidade (\%) $^{1}$ & Duração (dias) $^{1}$ \\
\hline Testemunha (água) & $81,2 \pm 7,61$ & $9,9 \pm 0,13$ \\
Testemunha (acetona) & $75,7 \pm 3,58$ & $10,2 \pm 0,21$ \\
Folhas de T. pallida(aquoso) & $85,6 \pm 3,44$ & $10,1 \pm 0,02$ \\
Folhas de T. pallida(clorofórmico) & $68,6 \pm 7,98$ & $9,8 \pm 0,07$ \\
\hline Médias, nas colunas, não diferem entre si, pelo teste de Tukey $(\mathrm{P} \leq 0,05)$.
\end{tabular}

De modo análogo, também o peso de pupas, machos e fêmeas, não foi afetado pelos tratamentos com extratos de folhas de T. pallida (Figura 7).

Quando se aumentou a concentração dos extratos de folhas de $T$. pallida de 5 para 10\%, ambos afetaram a sobrevivência larval. Os valores de viabilidade larval nos extratos aquoso $(70,2 \%)$ e clorofórmico $(52,7 \%)$ foram semelhantes entre si e intermediários entre aqueles observados na testemunha $(91,5 \%)$ e no tratamento com extrato de nim $(7,4 \%)$. Neste segundo experimento, a eficiência do extrato de nim em tratamento tópico foi ainda maior que no primeiro experimento, no qual a viabilidade larval tinha atingido $22,5 \%$. 
Em relação à duração dessa fase, os valores de 15,6 e 16,2 dias observados nos tratamentos com extrato aquoso e clorofórmico de folhas de T. pallida, respectivamente, foram superiores ao observado na testemunha (14,8 dias) (Tabela 16), evidenciando que nessa concentração, o tratamento tópico das lagartas alonga o seu período de desenvolvimento.

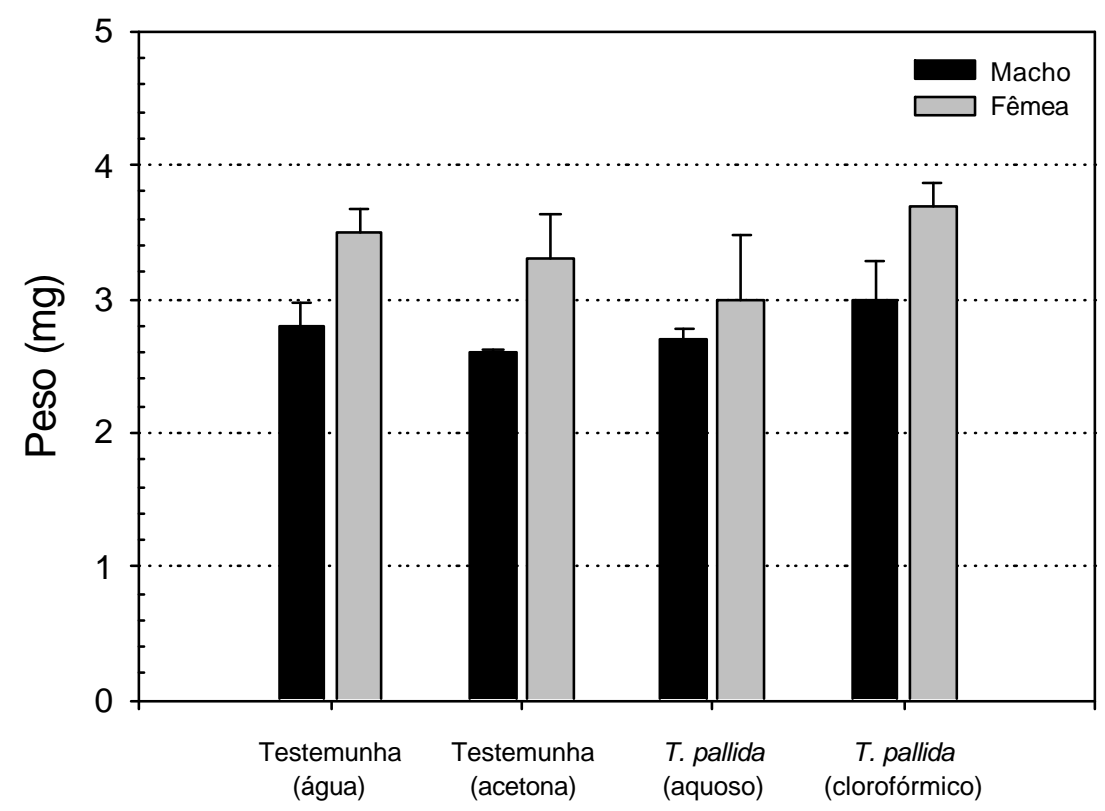

Figura 7 - Peso de pupas de T. absoluta tratada topicamente no segundo ínstar larval com extratos de T. pallida (5\%). Temp.: 25,18 \pm 2,10 ${ }^{\circ} \mathrm{C}$; UR: $69,55 \pm 10,80 \%$; fotofase: $12 \mathrm{~h}$ 
Tabela 16. Viabilidade e duração da fase larval de $T$. absoluta tratada topicamente no segundo ínstar larval com extratos de meliáceas. Temp.: $24,12 \pm 1,45^{\circ} \mathrm{C}$; UR: $69,80 \pm 10,12 \%$; fotofase: $12 \mathrm{~h}$

\begin{tabular}{lrc}
\hline \multicolumn{1}{c}{ Extratos } & Viabilidade (\%) $^{1}$ & Duração (dias) $^{1}$ \\
\hline Testemunha (água) & $91,5 \pm 2,88 \mathrm{a}$ & $14,8 \pm 0,32 \mathrm{a}$ \\
Folhas de T. pallida - aquoso (10\%) & $70,2 \pm 7,58 \mathrm{~b}$ & $15,6 \pm 0,16 \mathrm{~b}$ \\
Folhas de T. pallida- clorofórmico (10\%) & $52,7 \pm 5,84 \mathrm{~b}$ & $16,2 \pm 0,26 \mathrm{~b}$ \\
Sementes de nim (aquoso) (5\%) & $7,4 \pm 3,97 \mathrm{c}$ & $17,8 \pm 0,62^{2}$ \\
\hline Médias seguidas de mesma letra não diferem entre si, pelo teste de Tukey \\
(P $\leq$ 0,05).
\end{tabular}

${ }^{2}$ Não incluído na análise estatística devido ao número reduzido de repetições.

A fase pupal de $T$. absoluta não foi afetada em relação a nenhum dos parâmetros avaliados, quando as lagartas foram tratadas topicamente com os extratos aquoso e clorofórmico de folhas de T. pallida na concentração de $10 \%$ (Tabela 17 e Figura 8).

Tabela 17. Viabilidade e duração da fase pupal de $T$. absoluta tratada topicamente no segundo ínstar larval com extratos de $T$. pallida. Temp.: $24,82 \pm 1,50^{\circ} \mathrm{C}$; UR: $69,14 \pm 10,91 \%$; fotofase: $12 \mathrm{~h}$

\begin{tabular}{lcc}
\hline \multicolumn{1}{c}{ Extratos } & Viabilidade (\%) $^{1}$ & Duração (dias) $^{1}$ \\
\hline Testemunha (água) & $77,2 \pm 4,26$ & $10,0 \pm 0,13$ \\
Folhas de T. pallida - aquoso (10\%) & $78,4 \pm 7,65$ & $9,8 \pm 0,19$ \\
Folhas de T. pallida - clorofórmico (10\%) & $79,8 \pm 6,53$ & $9,7 \pm 0,16$
\end{tabular}

Médias, nas colunas, não diferem entre si, pelo teste de Tukey $(\mathrm{P} \leq 0,05)$. 


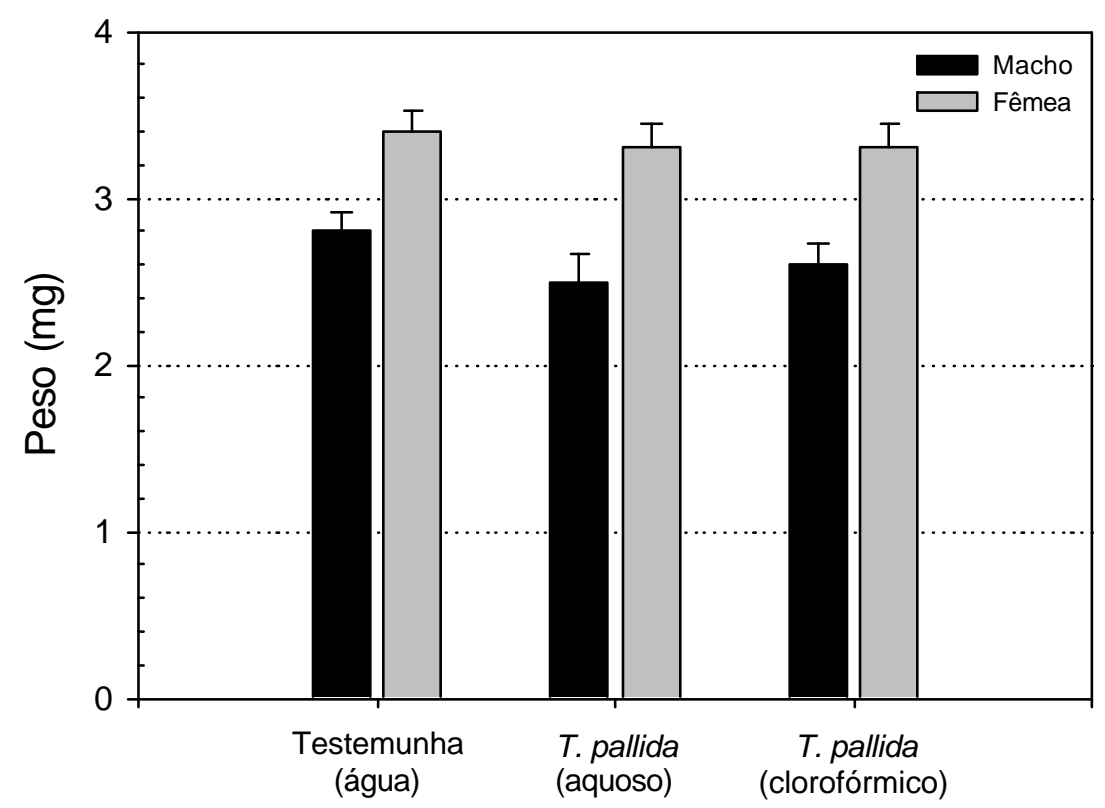

Figura 8 - Peso de pupas de T. absoluta tratada topicamente no segundo ínstar larval com extratos de T. pallida (10\%). Temp.: 24,82 \pm $1,50^{\circ} \mathrm{C}$; UR: $69,14 \pm 10,91 \%$; fotofase: $12 \mathrm{~h}$

Considerando o efeito tópico, os extratos de folhas de T. pallida mostraram resultados adversos em relação à traça-do-tomateiro mesmo na menor concentração utilizada (5\%). Nessa concentração observou-se menor viabilidade larval no tratamento correspondente ao extrato clorofórmico e maior duração da fase provocada pelo extrato aquoso. Esses resultados foram reforçados com o aumento da concentração dos extratos (de 5 para 10\%), quando se confirmou o efeito deletério dos mesmos, tanto na viabilidade como no desenvolvimento dos insetos.

\subsubsection{Considerações gerais}

De modo geral, os extratos de folhas de T. pallida se mostraram menos eficientes em relação à traça-do-tomateiro do que o extrato aquoso de sementes de nim, o qual superou todos os tratamentos, independentemente da 
forma de aplicação e da concentração utilizada. Esses resultados reforçam a possibilidade de utilização desse extrato no controle da praga em questão.

Os extratos de folhas de $T$. pallida, embora em menor intensidade, também se mostraram ativos sobre $T$. absoluta em praticamente todos os testes realizados. O efeito de profundidade foi o mais evidente, uma vez que na concentração de $5 \%$ foi possível observar diferenças quanto à viabilidade larval e desenvolvimento do inseto, entre os extratos dessa espécie e o tratamento testemunha (água).

Por outro lado, esses extratos não foram tão eficientes quando aplicados no solo. Apesar do alongamento da fase larval provocada pelos dois extratos (aquoso e clorofórmico), a sobrevivência larval não foi afetada, mesmo na maior concentração utilizada (5\%).

Considerando o efeito tópico, na concentração de 5\%, foi observado efeito significativo do extrato clorofórmico no que diz respeito àviabilidade larval e do aquoso em relação à duração dessa fase, sendo que a $10 \%$ os dois extratos foram mais eficientes (em comparação à testemunha) em relação a esses dois parâmetros.

O modo de ação de compostos presentes em extratos de plantas do gênero Trichilia ainda é pouco conhecido. Wheler \& Isman (2001), estudando a atividade biológica de extratos metanólicos de $T$. americana sobre lagartas de Spodoptera litura $(F$.$) , verificaram que os mesmos não provocam efeito$ deletério quando aplicados topicamente ou por meio de injeção na hemocele dos insetos.

Diante dos resultados obtidos, fica evidente que a traça-do-tomateiro é afetada adversamente pelos extratos aquosos e clorofórmicos de $T$. pallida e que os mesmos atuam principalmente sobre a fase larval do inseto. Thomazini et al. (2000) chegaram a essa mesma constatação em estudos envolvendo extrato aquoso $(0,1$ e $5 \%)$ de folhas dessa meliácea e a traça-do-tomateiro. Os autores justificaram que isso pode ser explicado pelo fato de ser nessa fase que 
0 inseto se alimenta, ficando portanto, mais exposto aos possíveis aleloquímicos presentes na planta inseticida.

Na maioria dos testes realizados, além da redução na viabilidade larval, os extratos de folhas de T. pallida, principalmente o aquoso, provocaram alongamento dessa fase. O aumento na duração da fase larval do inseto pode ser atribuído a menor eficiência de conversão do alimento digerido causada pelo desvio de parte dele para degradação de substâncias tóxicas presentes no substrato alimentar (Tanzubil \& McCafferry, 1990).

Uma vez confirmada a possibilidade de utilização de extratos aquosos e orgânicos de T. pallida, bem como do extrato aquoso de sementes de nim para controle da traça-do-tomateiro, justifica-se a avaliação de um possível efeito desses extratos sobre inimigos naturais desse inseto. Esse estudo pode fornecer informações importantes para utilização conjunta desses dois métodos em programas de manejo integrado de T. absoluta. Dessa forma, com base nos resultados obtidos no presente trabalho, selecionou-se a maior concentração dos extratos utilizada nos diferentes experimentos (10\%) para ser testada sobre Trichogramma pretiosum Riley, 1879, importante parasitóide de ovos da traçado-tomateiro.

\subsection{Efeito de extratos de meliáceas sobre o parasitóide T. pretiosum}

\subsubsection{Tratamento dos ovos antes do parasitismo}

\subsubsection{Teste com chance de escolha}

A acetona utilizada para diluição do extrato clorofórmico não provocou efeito sobre os parasitóides, uma vez que a solução água + acetona não diferiu da testemunha (água) em nenhum dos parâmetros avaliados.

Não foi verificado efeito dos extratos de T. pallida sobre o parasitismo de T. pretiosum, quando cartelas contendo ovo s de Anagasta kuehniella (Zeller, 
1879) tratados com os diferentes extratos foram oferecidas à fêmeas desse parasitóide juntamente com o tratamento testemunha (água). O número de ovos parasitados, tanto no tratamento com extrato aquoso, quanto no clorofórmico dessa espécie foi semelhante ao observado na testemunha. Por outro lado, o extrato aquoso de sementes de nim a $10 \%$ reduziu drasticamente o número de ovos parasitados por T. pretiosum (Tabela 18).

Tabela 18. Número de ovos de A. kuehniella previamente tratados com extratos de meliáceas e parasitados por $T$. pretiosum. Temp.: $25 \pm 2^{\circ} \mathrm{C}$; UR: $70 \pm 10 \%$; fotofase: $14 \mathrm{~h}$

\begin{tabular}{llll}
\hline \multicolumn{1}{c}{ Extratos } & \multicolumn{2}{c}{ № de ovos parasitados } & \multirow{2}{*}{ Teste "t" } \\
& Tratamento & Testemunha & \\
\hline Água + acetona & $47,4 \pm 5,87$ & $51,1 \pm 3,72$ & $0,6069 \mathrm{~ns}$ \\
Folhas de T. pallida (aquoso) & $43,2 \pm 6,44$ & $52,2 \pm 7,40$ & $0,6261 \mathrm{~ns}$ \\
Folhas de T. pallida(clorofórmico) & $41,7 \pm 4,07$ & $56,8 \pm 7,70$ & $0,1160 \mathrm{~ns}$ \\
Sementes de nim (aquoso) & $15,2 \pm 4,23$ & $49,4 \pm 7,07$ & 0,0009 * \\
\hline
\end{tabular}

Nesse teste, o extrato aquoso de sementes de nim, também foi o único tratamento que afetou de forma negativa a emergência do parasitóide $T$. pretiosum. Enquanto na testemunha foi observada emergência de $99,0 \%$, esse valor foi reduzido para $71,7 \%$ no tratamento correspondente ao extrato de sementes de nim (Tabela 19). A longevidade das fêmeas que entraram em contato com os ovos tratados não foi afetada por nenhum dos extratos avaliados (Figura 9). 
Tabela 19. Emergência de T. pretiosum em ovos de A. kuehniella previamente tratados com extratos de meliáceas. Temp.: $25 \pm 2^{\circ} \mathrm{C}$; UR: $70 \pm$ $10 \%$; fotofase: $14 \mathrm{~h}$

\begin{tabular}{llll}
\hline \multicolumn{1}{c}{ Extratos } & \multicolumn{2}{c}{ Emergência (\%) } & \multirow{2}{*}{ Teste "t" } \\
& Tratamento & Testemunha & \\
\hline Água + acetona & $98,3 \pm 0,50$ & $98,9 \pm 0,40$ & $0,6347 \mathrm{~ns}$ \\
Folhas de T. pallida(aquoso) & $98,3 \pm 0,79$ & $99,1 \pm 0,43$ & $0,6654 \mathrm{~ns}$ \\
Folhas de T. pallida(clorofórmico) & $98,6 \pm 0,55$ & $98,9 \pm 0,51$ & $0,7055 \mathrm{~ns}$ \\
Semente de nim (aquoso) & $71,7 \pm 4,24$ & $99,0 \pm 0,39$ & 0,0001 * \\
\hline
\end{tabular}

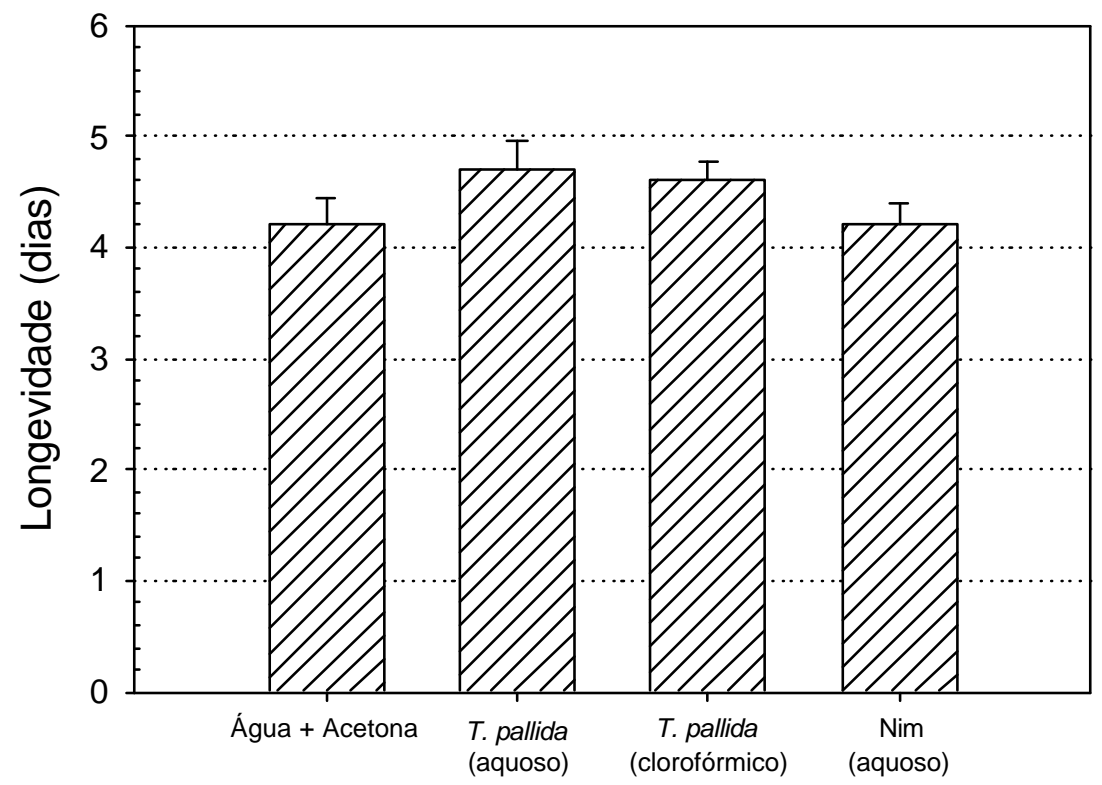

Figura 9 - Longevidade de fêmeas de T. pretiosum após o contato com ovos tratados com solução (água + acetona) e extratos de folhas de $T$. pallida e de sementes de nim. Temp.: $25 \pm 2^{\circ} \mathrm{C}$; UR: $70 \pm 10 \%$; fotofase: $14 \mathrm{~h}$ 
O efeito negativo do extrato aquoso de sementes de nim sobre $T$. pretiosum em teste de livre escolha já havia sido demonstrado por GonçalvesGervásio \& Vendramim (2003). Os autores verificaram que mesmo numa concentração de $5 \%$, esse extrato é deletério para o parasitóide em questão e que extratos aquosos de folhas de T. pallida em concentrações menores que $5 \%$ não apresentam efeito sobre o parasitismo e emergência de T. pretiosum em ovos de $A$. kuehniella.

A toxicidade de produtos à base de nim sobre parasitóides do gênero Trichogramma também foi verificada por Raguran \& Singh (1999). Em teste com chance de escolha, o pré-tratamento de ovos de Corcyra cephalonica (Stainton) com o óleo de sementes de nim, em concentrações que variaram de 0,3 a 5,0\%, reduziu significativamente o número de ovos parasitados por Trichogramma chilonis Ishii em todas as concentrações em comparação com a testemunha (ovos não tratados).

\subsubsection{Teste sem chance de escolha}

Quando o parasitóide foi confinado em tubos contendo apenas uma cartela de ovos (teste sem chance de escolha), não houve efeito dos extratos de folhas de $T$. pallida, bem como da acetona no que diz respeito ao número de ovos parasitados, emergência do parasitóide e longevidade das fêmeas que entraram em contato com os ovos tratados. Os dois primeiros parâmetros, por sua vez, foram afetados pelo tratamento dos ovos com o extrato de sementes de nim, cujos valores (50,7 ovos parasitados e $87,7 \%$ de emergência) foram significativamente inferiores aos obtidos nos demais tratamentos, os quais variaram de 77,7 a 87,3 ovos parasitados, e de 99,1 a $99,5 \%$ de emergência (Tabela 20). 
Tabela 20. Número de ovos parasitados, emergência de T. pretiosum em ovos de $A$. kuehniella previamente tratados com extratos aquosos de nim e T. pallida e longevidade dos insetos após contato com ovos tratados. Temp.: $25 \pm 2^{\circ} \mathrm{C}$; UR: $70 \pm 10 \%$; fotofase: $14 \mathrm{~h}$

\begin{tabular}{lccc}
\hline \multicolumn{1}{c}{ Extratos } & $\begin{array}{c}\text { No } \text { de ovos }^{1} \\
\text { parasitados }\end{array}$ & $\begin{array}{c}\text { Emergência } \\
(\%)^{1}\end{array}$ & $\begin{array}{c}\text { Longevidade } \\
\text { (dias) }^{2}\end{array}$ \\
\hline Testemunha (água) & $87,3 \pm 4,03 \mathrm{a}$ & $99,3 \pm 0,20 \mathrm{a}$ & $4,6 \pm 0,23$ \\
Água + acetona & $77,7 \pm 5,07 \mathrm{a}$ & $99,5 \pm 0,22 \mathrm{a}$ & $4,3 \pm 0,31$ \\
Folhas de T. pallida (aquoso) & $85,4 \pm 5,18 \mathrm{a}$ & $99,2 \pm 0,24 \mathrm{a}$ & $3,9 \pm 0,23$ \\
Folhas de T. pallida (clorofórmico) & $86,5 \pm 9,01 \mathrm{a}$ & $99,1 \pm 0,25 \mathrm{a}$ & $4,3 \pm 0,34$ \\
Semente de nim (aquoso) & $50,7 \pm 5,51 \mathrm{~b}$ & $87,7 \pm 1,39 \mathrm{~b}$ & $3,8 \pm 0,13$
\end{tabular}

${ }^{1}$ Médias seguidas de mesma letra não diferem entre si, pelo teste de Tukey $(P \leq 0,05)$.

${ }^{2}$ Médias, nas colunas, não diferem entre si, pelo teste de Tukey $(P \leq 0,05)$.

Hohmann et al. (2002) também verificaram redução drástica no número de ovos de A. kuehniellaparasitados por T. pretiosum, quando os mesmos foram tratados com extrato aquoso de sementes de nim a $15 \%$. Os autores também observaram que esse extrato reduz em até $88 \%$ a emergência do parasitóide em relação àtestemunha (água).

Gonçalves-Gervásio \& Vendramim (2003), em testes de confinamento, verificaram que na concentração de $5 \%$ o extrato aquoso de sementes de nim não afeta o número de ovos parasitados por $T$. pretiosum. Essa concentração, entretanto, é suficiente para reduzir a emergência do parasitóide.

O efeito deterrente do óleo de sementes de nim foi demonstrado por Klemm \& Schmutterer (1993) em relação ao parasitismo de ovos de Plutella xylostella (L.) por insetos do gênero Trichogramma Os autores verificaram que a pulverização dos ovos com óleo de nim na concentração de $0,2 \%$ reduziu 0 
número de ovos parasitados por Trichogramma principium Sug. et Sor. em laboratório e por T. pretiosum em condições de campo.

\subsubsection{Tratamento dos ovos após o parasitismo}

Quando o tratamento dos ovos de A. kuehniella com extrato de sementes de nim foi feito quando o parasitóide ainda se encontrava na fase de ovo/larva (0-24h), houve redução no número de ovos escuros (com sintoma de parasitismo) (47,1 ovos), diferindo dos valores obtidos nos demais tratamentos, onde esse número variou de 162,2 a 187,2. Este efeito, entretanto, não foi observado quando esse tratamento foi realizado quando o parasitóide se encontrava na fase de pré-pupa e pupa, o que de certa forma já era esperado, pois nessa fase, os ovos parasitados já se encontravam escuros (em função da deposição de corpos de urato), indicando que o parasitóide já se encontrava no início da fase de pré-pupa. Por outro lado, a porcentagem de emergência do parasitóide foi reduzida, independentemente da fase em que o mesmo se encontrava no momento do tratamento com extrato de sementes de nim. Isso demonstra 0 efeito deletério desse extrato sobre todas as fases de desenvolvimento de $T$. pretiosum. Observourse que a fase de pupa foi a mais sensível àação do extrato (Tabela 21).

Os resultados aqui apresentados se assemelham aos obtidos por Hohmann et al. (2002), os quais observaram redução na porcentagem de emergência de $T$. pretiosum, quando ovos já parasitados de $A$. kuehniella foram tratados com extrato aquoso de nim na concentração de $15 \%$.

Raguran \& Singh (1999), entretanto, não observaram efeito deletério da aplicação de óleo de nim em concentrações que variaram de 0,3 a 5,0\% sobre ovos de $C$. cephalonica já parasitados por $T$. chilonis. Isso indica que produtos à base de nim em concentrações mais baixas podem ser compatíveis com o uso de parasitóides do gênero Trichogramma. 
Tabela 21. Parasitismo de T. pretiosum em ovos de A. kuehniella tratados com extratos de meliáceas durante diferentes fases de desenvolvimento do parasitóide. Temp.: $25 \pm 2^{\circ} \mathrm{C}$; UR: $70 \pm 10 \%$; fotofase: $14 \mathrm{~h}$

\begin{tabular}{|c|c|c|c|c|}
\hline \multirow{2}{*}{ Extratos } & \multicolumn{3}{|c|}{ Número de ovos escuros } & \multirow{2}{*}{ Média } \\
\hline & Ovo-larva & Pré-pupa & Pupa & \\
\hline Testemunha (água) & $162,2 \pm 12,96 \mathrm{aB}$ & $207,3 \pm 6,31 a A$ & $194,1 \pm 3,18 \mathrm{aA}$ & 187,9 \\
\hline Água + acetona & $187,2 \pm 9,23 \mathrm{aA}$ & $198,3 \pm 3,33$ aA & $191,9 \pm 2,35 a A$ & 192,5 \\
\hline T. pallida (aquoso) & $168,4 \pm 6,06 \mathrm{aB}$ & $197,6 \pm 3,11 \mathrm{aA}$ & $188,9 \pm 3,30 \mathrm{aAB}$ & 185,0 \\
\hline T. pallida (clorofórmico) & $175,9 \pm 9,99 \mathrm{aB}$ & $198,8 \pm 2,64 a A$ & $193,7 \pm 2,27 \mathrm{aAB}$ & 189,5 \\
\hline Nim (aquoso) & $47,1 \pm 8,39 \mathrm{bB}$ & $185,1 \pm 7,47 \mathrm{aA}$ & $174,4 \pm 4,12 \mathrm{aA}$ & 135,5 \\
\hline Média & 148,2 & 197,4 & 188,6 & \\
\hline
\end{tabular}

Os extratos de folhas de T. pallida não afetaram o desenvolvimento do parasitóide. Tanto o número de ovos com sintoma de parasitismo, como a porcentagem de emergência, não diferiu dos valores encontrados na testemunha (água) e na solução (água + acetona), as quais foram semelhantes entre si (Tabelas 21 e 22).

Gonçalves-Gervásio \& Vendramim (2002) também verificaram que extratos aquosos de folhas de T. pallida (1 e 5\%) não afetaram a emergência de T. pretiosum quando o tratamento dos ovos do hospedeiro foi efetuado após o parasitismo. 
Tabela 22. Emergência de $T$. pretiosum em ovos de A. kuehniella tratados com extratos de meliáceas durante diferentes fases de desenvolvimento do parasitóide. Temp.: $25 \pm 2^{\circ} \mathrm{C}$; UR: $70 \pm 10 \%$; fotofase: $14 \mathrm{~h}$

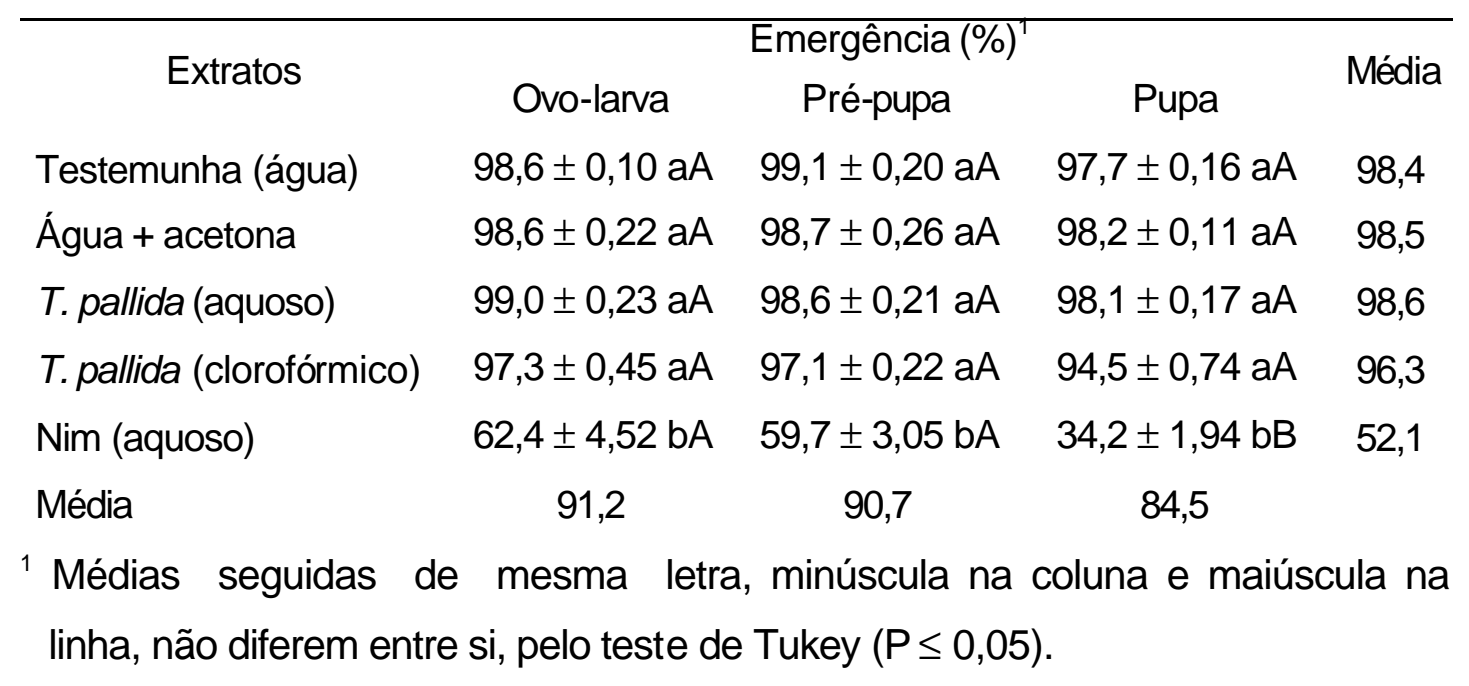

Os insetos provenientes dos ovos tratados aparentemente não foram afetados pelos extratos, já que não foram observadas diferenças entre as fêmeas provenientes dos diferentes tratamentos, no que diz respeito ao número de ovos parasitados e porcentagem de emergência (Tabelas 23 e 24).

Assim como o parasitismo e a emergência, os valores de longevidade das fêmeas provenientes de todos os tratamentos (variáveis de 5,6 a 6,5 dias) não diferiram entre $\mathrm{si}$, independentemente da fase em que 0 parasitóide se encontrava no momento do tratamento do ovo hospedeiro. 
Tabela 23. Parasitismo de fêmeas de $T$. pretiosum provenientes de ovos de $A$. kuehniella tratados com extratos de meliáceas durante diferentes fases de desenvolvimento do parasitóide. Temp.: $25 \pm 2^{\circ} \mathrm{C}$; UR: $70 \pm$ $10 \%$; fotofase: $14 \mathrm{~h}$

\begin{tabular}{|c|c|c|c|c|}
\hline \multirow{2}{*}{ Extratos } & \multicolumn{3}{|c|}{ Número de ovos escuros ${ }^{\top}$} & \multirow{2}{*}{ Média } \\
\hline & Ovo-lanva & Pré-pupa & Pupa & \\
\hline Testemunha (água) & $34,1 \pm 2,22$ & $30,1 \pm 2,25$ & $30,3 \pm 1,94$ & 31,5 \\
\hline Água + acetona & $33,1 \pm 1,97$ & $32,1 \pm 2,17$ & $31,0 \pm 1,52$ & 32,1 \\
\hline T. pallida (aquoso) & $32,1 \pm 1,98$ & $30,4 \pm 1,74$ & $34,6 \pm 1,58$ & 32,4 \\
\hline T. pallida (clorofórmico) & $34,5 \pm 2,48$ & $28,1 \pm 3,06$ & $28,9 \pm 2,28$ & 30,5 \\
\hline Nim (aquoso) & $31,9 \pm 2,27$ & $32,0 \pm 2,52$ & $29,4 \pm 2,61$ & 31,1 \\
\hline Média & $33,1 \mathrm{a}$ & $30,5 b$ & $30,8 b$ & \\
\hline
\end{tabular}

Médias, nas colunas, não diferem entre si, pelo teste de Tukey $(\mathrm{P} \leq 0,05)$.

Tabela 24. Emergência (segunda geração) de T. pretiosum em ovos de $A$. kuehniella tratados com extratos de meliáceas durante diferentes fases de desenvolvimento do parasitóide. Temp.: $25 \pm 2^{\circ} \mathrm{C}$; UR: 70 $\pm 10 \%$; fotofase: $14 \mathrm{~h}$

\begin{tabular}{lcccc}
\hline \multicolumn{1}{c}{ Extratos } & \multicolumn{3}{c}{ Emergência (\%) $^{1}$} & Média \\
& Ovo-larva & Pré-pupa & Pupa & \\
\hline Testemunha (água) & $98,7 \pm 0,49$ & $98,2 \pm 0,56$ & $98,5 \pm 0,55$ & 98,5 \\
Água + acetona & $98,2 \pm 0,47$ & $98,3 \pm 0,58$ & $90,0 \pm 8,16$ & 95,5 \\
T. pallida (aquoso) & $97,7 \pm 0,63$ & $98,7 \pm 0,47$ & $97,9 \pm 0,64$ & 98,1 \\
T. pallida (clorofórmico) & $99,1 \pm 0,42$ & $97,9 \pm 0,59$ & $98,5 \pm 0,58$ & 98,5 \\
Nim (aquoso) & $97,8 \pm 0,50$ & $98,4 \pm 0,54$ & $97,5 \pm 0,58$ & 97,9 \\
Média & 98,3 & 98,3 & 96,5 & \\
\hline
\end{tabular}

Médias, nas colunas, não diferem entre si, pelo teste de Tukey $(P \leq 0,05)$. 


\subsubsection{Considerações gerais}

O extrato aquoso de sementes de nim na concentração de $10 \%$ afetou de forma negativa o parasitóide T. pretiosum. Esse extrato apresentou efeito repelente sobre as fêmeas do parasitóide, reduzindo de forma significativa o parasitismo sobre ovos de A. kuehniella. Além da repelência, constatou-se que o extrato prejudica o desenvolvimento do inseto no interior do ovo hospedeiro, efeito caracterizado pela redução na porcentagem de emergência. Entretanto, nos testes com $T$. absoluta, o extrato aquoso de nim apresentou resultados satisfatórios sobre a praga mesmo em baixas concentrações. De acordo com Gonçalves-Gervásio \& Vendramim (2003), o extrato aquoso de sementes de nim na concentração de $1 \%$ não apresenta efeito deletério sobre o parasitismo de ovos de A. kuehniella por $T$. pretiosum, mostrando que uma redução na concentração do extrato pode permitir que o mesmo seja utilizado juntamente com o parasitóide no controle de pragas. Além disso, no presente trabalho, ficou demonstrada a possibilidade de utilização desse extrato diretamente no solo, uma vez que o mesmo apresenta atividade sistêmica sobre a traça-dotomateiro. Dessa forma, esse tipo de aplicação poderia ser adotado em programas de manejo integrado da praga em questão, com o objetivo de proteger os parasitóides do contato direto com os extratos.

Constatou-se, por outro lado, que os extratos de folhas de T. pallida, na concentração de 10\%, não afetaram os parasitóides, independentemente do momento em que os ovos do hospedeiro foram tratados (antes ou após o parasitismo). Assim, acredita-se que a utilização desses extratos, mesmo em aplicações na parte aérea da planta, seja compatível com a liberação de $T$. pretiosum para controle da traça-do-tomateiro. No caso dessa praga, essa condição é desejável em virtude da baixa eficiência apresentada pelos extratos de folha de $T$. pallida sobre a mesma, quando aplicados de forma sistêmica (aplicação no solo). 
A possibilidade de utilização de parasitóides em associação com extratos vegetais no controle de pragas pode se constituir numa boa alternativa em programas de manejo integrado. Essa estratégia pode permitir a utilização de extratos menos concentrados, o que é de grande interesse, uma vez que os mesmos podem apresentar efeito fitotóxico quando aplicados em altas concentrações, sendo esse efeito, relatado, principalmente para produtos à base de nim (Martinez, 2002; Meisner et al., 1978).

Diante dessas considerações, os resultados aqui obtidos, sugerem estudos complementares, envolvendo extratos de nim e T. pallida juntamente com o parasitóide $T$. pretiosum no controle de $T$. absoluta, com o objetivo de se determinar o efeito associado dessas táticas de controle sobre a praga. 


\section{CONCLUSÕES}

Nas condições em que os experimentos foram conduzidos, foi possível concluir que:

- Extratos aquosos de sementes de nim apresentam efeitos translaminar, sistêmico e por contato sobre $T$. absoluta, provocando alta mortalidade em concentrações menores do que $5 \%$.

- O extrato clorofórmico de folhas de T. pallida é mais eficiente que os extratos hexânico e aquoso em relação àtraça-do-tomateiro.

- Extratos aquosos e clorofórmicos de folhas de T. pallida em concentrações maiores do que $5 \%$ prejudicam o desenvolvimento de $T$. absoluta, atuando de forma translaminar, sistêmica e por contato, sendo o efeito translaminar mais pronunciado que os demais.

- O parasitóide de ovos T. pretiosum é sensível ao extrato aquoso de sementes de nim na concentração de $10 \%$, quando o mesmo é aplicado sobre ovos do hospedeiro antes ou depois do parasitismo.

- Extratos aquosos e clorofórmicos de folhas de T. pallida na concentração de 10\% não afetam o parasitismo e nem o desenvolvimento do parasitóide T. pretiosum no interior do ovo hospedeiro. 


\section{REFERÊNCIAS BIBLIOGRÁFICAS}

ABRAHAM, C.C.; AMBIKA, B. Effect of leaf and kernel extracts of neem on moulting and vitellogenesis in Dysdercus cingulatus Fabr. (Heteroptera: Pyrrhocoridae). Current Science, v.48, n.12, p.554-556, 1979.

ASCHER, K.R.S.; ELIYAHU, M.; NEMNY, N.E.; MEISNER, J. Neem seed kernel extract as inhibitor of growth and fecundity in Spodoptera littoralis. In: INTERNATIONAL NEEM CONFERENCE, 2., Rauischlolzhausen, 1984. Natural pesticides from the neem tree (Azadirachta indica A. Juss) and other tropical plants. Eschborn: GTZ Press, 1984. p.331-344.

BAUTISTA, M.N.; MORALES, G.O.; CARRILO, S.J.L.; BRAVO, M.H. Mortalidad de Phyllocnistis citrella con un aceite mineral y nim. Manejo Integrado de Plagas, n.50, p.29-33, 1998.

BOGORNI, P.C. Efeito de extratos aquosos de Trichilia spp. sobre o desenvolvimento de Spodoptera frugiperda (J.E. Smith) em milho. Piracicaba, 2003. 65p. Tese (Doutorado) - Escola Superior de Agricultura "Luiz de Queiroz", Universidade de São Paulo. 
BORAD, P.K.; PATEL, M.J.; VAGHELA, N.M.; PATEL, B.H.; PATEL, M.G.; PATEL, B.H.; PATEL, J.R. Evaluation of some botanicals against citrus leafminer (Phyllocnistis citrella) and Psylla (Diaphorina citri) on kagzilime (Citrus aurantifolia). Indian Journal of Agricultural Sciences, v.71, n.3, p.177-179, 2001.

BOTTO, E.N. Control biológico de plagas hortícolas en ambientes protegidos. Revista de la Sociedad Entomologica Argentina, v.58, n.1/2, p.58-64, 1999.

BREUER, M.; DEVKOTA, B. Control of Thaumetopea pityocampa (Den.; Schiff.) by extracts of Melia azedarach L. (Meliaceae). Journal of Economic Entomology, v.65, n.2, p.385-386, 1990.

BRUNHEROTTO, R. Bioatividade de extratos aquosos de Melia azedarach L. e Azadirachta indica A. Juss (Meliaceae) sobre Tuta absoluta (Meyrick, 1917) (Lep., Gelechiidae) criadas em diferentes genótipos de tomateiro. Piracicaba, 2000. 76p. Dissertação (Mestrado) - Escola Superior de Agricultura "Luiz de Queiroz", Universidade de São Paulo.

CANO, E.; GLADSTONE, S.M. Efecto del insecticida botanico, Nim-20, sobre el parasitismo por Trichogramma pretiosum en huevos de Helicoverpa zea en el cultivo del melon. Manejo Integrado de Plagas, n.33, p.23-25, 1994.

CASTELO BRANCO, M. Controle químico da traça do tomateiro. Horticultura Brasileira, v.8, n.1, p.25, 1990. 
CÔNSOLI, F.L.; PARRA, J.R.P.; HASSAN, S.A. Side-effects of insecticides used in tomato fields on the egg parasitoid Trichogramma pretiosum Riley (Hym., Trichogrammatidae), a natural enemy of Tuta absoluta (Meyrick) (Lep., Gelechiidae). Journal of Applied Entomology, v.122, p.43-47, 1998.

DOMINGUES, G.R.; OLIVEIRA, H.N.; PARRA, J.R.P. Controle da traça-dotomateiro Tuta absoluta (Meyrick, 1917) (Lepidoptera: Gelechiidae) em cultivo protegido de tomateiro, com liberações de Trichogramma pretiosum Riley, 1879. In: SIMPÓSIO DE CONTROLE BIOLÓGICO, 8., São Pedro: SEB, 2003. Resumos. São Pedro: 2003. p.115.

FAGOONEE, I.; TOORY, V. Contribution to the study of the biology and ecology of the leafminer Liriomyza trifolii and its control by neem. Insect Science and its Applications, v.5, n.1, p.23-30, 1984.

FERRACINI, V.L.; WATANABE, M.A.; FRIGHETTO, R.T.S.; SILOTO, R.C. Controle da traça do tomateiro Scrobipalpula absoluta, utilizando extratos vegetais. In: CONGRESSO BRASILEIRO DE ENTOMOLOGIA, 13., Recife, 1991. Resumos. Recife: SEB, 1991. p.356.

FERRACINI, V.L.; WATANABE, M.A.; SILOTO, R.C. Controle da traça-dotomateiro Scrobipalpuloides absoluta (Lepidoptera: Gelechiidae) (Meyrick, 1917) em plantas de tomate Lycopersicon esculentum (Mill.) envasadas, usando extratos vegetais. In: CONGRESSO BRASILEIRO DE ENTOMOLOGIA, 14., Piracicaba, 1993. Resumos. Piracicaba: SEB, 1993. p.630. 
FERREIRA, J.A.M.; ANJOS, N. Caracterização dos ínstares larvais de Tuta absoluta (Meyrick) (Lepidoptera: Gelechiidae). In: CONGRESSO BRASILEIRO DE ENTOMOLOGIA, 16., Salvador, 1997. Resumos. Salvador: SEB/ EMBRAPA-CNPMF, 1997. p.64

FRANÇA, F.H.; CASTELO BRANCO, M.; VILLAS BÔAS, G.L.; GIORDANO, L.B.; KOMATSU, K. Liberações semanais de Trichogramma pretiosum controlam a traça-do-tomateiro em tomate para processamento industrial no Distrito Federal. Horticultura Brasileira, v.11, n.1, p.72, 1993.

FRANÇA, F.H.; COELHO, M.C.F.; HORINO, Y. Controle químico da traça do tomateiro, broca pequena e broca grande em tomate. Horticultura Brasileira, v.3, n.1, p.43, 1985.

GIUSTOLIN, T.A.; VENDRAMIM, J.D. Biologia de Scrobipalpuloides absoluta (Meyrick), em folhas de tomateiro, em laboratório. Ecossistema, v.21, p.1115, 1996.

GONÇALVES, C.R.; OLIVEIRA, A.; LIMA, A.F. Scrobipalpula absoluta (Meyrick) (Lepidoptera-Gelechiidae), uma nova broca do tomateiro no Estado do Rio de Janeiro. In: CONGRESSO BRASILEIRO DE ENTOMOLOGIA, 8., Brasília, 1983. Resumos. Brasília: SEB, 1983. p.73.

GONÇALVES-GERVÁSIO, R.C.R.; VENDRAMIM, J.D. Efeito de extratos de Trichilia pallida sobre o parasitóide de ovos Trichogramma pretiosum. In: CONGRESSO BRASILEIRO DE ENTOMOLOGIA, 19., Manaus, 2002. Resumos. Manaus: SEB, 2002. p.76-77. 
GONÇALVES-GERVÁSIO, R.C.R.; VENDRAMIM, J.D. Efeito de extratos de meliáceas sobre o parasitóide de ovos Trichogramma pretiosum. In: SIMPÓSIO DE CONTROLE BIOLÓGICO, 8., São Pedro, 2003. Resumos. São Pedro: SEB, 2003. p.164.

GOVINDACHARI, T.R.; SURESH, G.; GOPALAKRISHNAN, G.; WESLEY, S.D. Insect antifeedant and growth regulating activities of neem seed oil - the role of major tetranortriterpenoids. Journal of Applied Entomology, v.124, p.287-291, 2000.

GROPPO, G.A. A Scrobipalpula absoluta no tomate. Correio Agrícola, n.2, p.530, 1983.

HADDAD, M.L.; VENDRAMIM, J.D. Comparação de porcentagens observadas com casos extremos de 0 e 100\%. Anais da Sociedade Entomológica do Brasil, v.29, n.4, p.835-837, 2000.

HAJI, F.N.P.; FREIRE, L.C.L.; ROA, F.G.; SILVA, C.N. da; SOUZA JÚNIOR, M.M.; SILVA, M.I.V. da. Manejo integrado de Scrobipalpuloides absoluta (Povolny) (Lepidoptera: Gelechiidae) no Submédio São Francisco. Anais da Sociedade Entomológica do Brasil, v.24, n.3, p.587-591, 1995.

HOHMANN, C.L.; NOVAES, T.G. de; SILVA, F.A.C. da; ANDRADE, E.A. de. Effect of neem, Azadirachta indica A. Juss. on Trichogramma pretiosum Riley and Trichogrammatoidea annulata De Santis. In: INTERNATIONAL EGG PARASITOID SYMPOSIUM, 6., Perugia, 2002. Abstract. Perugia: IOBC, 2002. p.33-34. 
HOLMES, M.; HASSAN, E. The contact and systemic action of neem seed extract against greem peach aphid Myzus persicae Sulzer (Hemiptera: Aphididae). Azadirachta indica A. Juss, p.93-101, 1999.

ISMAN, M.B.; Growth inhibitory and antifeedant effects of azadiractin on six noctuids of regional economic importance. Pesticide Science, v.38, p.5763, 1993.

ISMAN, M. B.; KOUL, O.; LUCZYNSKI, A.; KAMINSKI, J. Insecticidal and antifeeding bioactivities of neem oils and their relationship to azadirachtin content. Journal of Agricultural and Food Chemistry, v.38, p.1406-1411, 1990.

JAGLAN, M.S.; KHOKHAR, K.S.; MALIK, M.S.; SINGH, R. Evaluation of neem (Azadirachta indica A. Juss) extracts against American bollworm, Helicoverpa armigera (Hubner). Journal of Agricultural and Food Chemistry, v.45, p.3262-3268, 1997.

KLEMM, U.; SCHMUTTERER, $\mathrm{H}$. Effects of neem preparations on Plutella xylostella $\mathrm{L}$. and its natural enemies of the genus Trichogramma. Journal of Plant Diseases and Protection, v.100, n.2, p.113-128, 1993.

KOUL, O.; ISMAN, M.B.; KETKAR, C.M. Properties and use of neem, Azadirachta indica. Canadian Journal of Botany, v.68, p.1-11, 1990.

LAGUNES, T.A.; RODRÍGUEZ, H.C. Búsqueda de tecnología apropiada para el combate de plagas del maíz almacenado en condiciones rústicas. Chapingo: CONACYT - CP, 1989. 150p. (Informe final del Proyecto CONACYT/PVT/AI/NAL/85/3149). 
LAREW, H.G.; KNODEL-MONTZ, J.J.; WEBB, R.E.; WARTHEN, J.D. Liriomyza trifolii (Burguess) (Diptera: Agromyzidae) control on chrysanthemum by neem seed extract applied to soil. Journal of Economic Entomology, v.78, n.1, p.80-84, 1985.

MARTINEZ, S.S. (Ed). O nim Azadirachta indica - natureza, usos múltiplos, produção, Londrina: Instituto Agronômico do Paraná, 2002. 142p.

MARTINEZ, S.S.; van ENDEM, H.F. Growth disruption, abnormalities and mortality of Spodoptera littoralis caused by azadirachtin. Neotropical Entomolgy, v.30, n.1, p.113-125, 2001.

MCMILLIAN, W.W.; BOWMAN, M.C.; BURTON, R.L.; STARKS, K.J.; WISEMAN, B.R. Extract of chinaberry leaf as a feeding deterrent and growth retardant for larvae of the corn earworm and fall armyworm. Journal of Economic Entomology, v.62, n.3, p.708-710, 1969.

MEISNER, J.; KEHAT, M.; ZUR, M.; EIZICK, C. Response of Earias insulana Boisd. larvae to neem (Azadirachta indica A. Juss) kernel extract. Phytoparasitica, v. 6, n.2, p.85-88, 1978.

MEISNER, J.; MELAMED-MADJAR, V.; YATHOM, S.; ASCHER, K.R.S.; SCHMUTTERER, R. The influence of neem on the European corn borer (Ostrinia nubilalis) and the serpentine leafminer. In: INTERNATIONAL NEEM CONFERENCE, 3., Nairobi, 1986. Natural pesticides from the neem tree (Azadirachta indica A. Juss) and other tropical plants. 1987, p. $461-477$. 
MIKOLAJCZAK, K.L.; REED, D.K. Extractives of seeds of the Meliaceae: Effects on Spodoptera frugiperda (J.E. Smith), Acalymma vittatum (F.), and Artemia salina Leach. Journal of Chemical Ecology, v. 13, n. 1, p. 99-111, 1987.

MIKOLAJCZAK, K.L.; ZILKOWSKI, B.W.; BARTELT, R.J. Effect of meliaceous seed extracts on growth and survival of Spodoptera frugiperda (J.E. Smith). Journal of Chemical Ecology, v.15, n.1, p.121-128, 1989.

MORAES, G.J.; NORMANHA FILHO, J.A. Surto de Scrobipalpula absoluta (Meyrick) em tomateiro no trópico semi-árido. Pesquisa Agropecuária Brasileira, v.17, n.3, p.503-504, 1982.

MORDUE (LUNTZ), A.J.; BLACKWELL, A. Azadirachtin: an update. Journal of Insect Physiology, v.39, n.11, p.903-924, 1993.

MORDUE (LUNTZ), A.J.; SIMONDS, M.S.J.; LEY, S.V.; BLANEY, M.; MORDUE, W.; NASIRUDDIN, M.; NISBET, A.J. Action of azadirachtin, a plant allelochemical, against insects. Pesticide Science, v.54, p.277-284, 1998.

MOREIRA, J.O.T.; LARA, F.M.; CHURATA-MASCA, M.G.C. Ocorrência de Scrobipalpula absoluta (Meyrick) (Lepidoptera:Gelechiidae) danificando tomate rasteiro em Jaboticabal SP. In: CONGRESSO BRASILEIRO DE ENTOMOLOGIA, 7., Fortaleza, 1982. Anais. Fortaleza: SEB, 1982. p.58.

MUSZINSKI, T.; LAVENDOWSKI, L.M.; MASCHIO, L.M. Constatação de Scrobipalpula absoluta (Meyrick, 1917) [Gnorimoschema absoluta] (Lepidoptera, Gelechiidae), como praga do tomateiro (Lycopersicon esculentum Mill.), no litoral do Paraná. Anais da Sociedade Entomológica do Brasil, v.11, n.2, p.291-292, 1982. 
NAKANISHI, K. Recent studies on bioactive compounds from plants. Journal of Natural Products, v.45, n.1, p.15-26, 1982.

NAKATANI, M.; IWASHITA, T.; NAOKI, H.; HASE, T. Structure of a limonoid antifeedant from Trichilia roka. Phytochemistry, v.24, n.1, p.195-196, 1985.

NAVARRO, M.A. Biological control of Scrobipalpula absoluta (Meyrick) by Trichogramma sp. In the tomato (Lycopersicon esculentum Mill.). In: INTERNATIONAL SIMPOSIUM ON TRICHOGRAMMA AND OTHER EGG PARASITOIDS, 2., Guangzhou, 1988. Proceedings. Guangzhou: INRA, 1988. p.453-458.

ORTEGO, O.; LÓPEZ-OLGUÍN, J.; RUÍZ, M.; CASTAÑERA, P. Effects of toxic and deterrent terpenoids on digestive protease and detoxication enzime activities of Colorado potato beetle larvae. Pesticide Biochemistry and Physiology, v.63, p.76-84, 1999.

OSMAN, M.Z. Effects of neem seed extract on growth and development of larvae of Pieris brassicae L. (Lep., Pieridae). Journal of Applied Entomology, v. 115, p.254-258, 1993.

OSMAN, M.Z.; PORT, G.R. Systemic action of neem seed substances against Pieris brassicae. Entomologia Experimentallis et Applicata, v.54, p.297300, 1990.

PAULO, A.D. Época de ocorrência de Scrobipalpula absoluta (Meyrick) (Lepidoptera-Gelechiidae) na cultura de tomate (Lycopersicon esculentum Mill) e seu controle. Piracicaba, 1986. 70p. Dissertação (Mestrado) - Escola Superior de Agricultura "Luiz de Queiroz", Universidade de São Paulo. 
PICANÇO, M.C.; SILVA, D.J.H. da; LEITE, G.L.D.; MATA, A.C. da; JHAM, B.N. Intensidade de ataque de Scrobipalpuloides absoluta (Meyrick, 1917) (Lepidoptera: Gelechiidae) ao dossel de três espécies de tomateiro. Pesquisa Agropecuária Brasileira, v.30, n.4, p. 429-433, 1995.

POVOLNÝ, D. On three Neotropical species of Gnorimoschemini (Lepidoptera, Gelechiidae) mining Solanaceae. Acta Universitis Agriculturae Facultas Agronomica, v.2, p.379-393, 1975.

POVOLNÝ, D. Gnorimoschemini of Southern America VI: identification keys, checklist of Neotropical taxa and general considerations (Insecta, Lepidoptera, Gelechiidae). Steenstrupia, v.20, n.1, p.1-42, 1994.

PRATISSOLI, D. Bioecologia de Trichogramma pretiosum Riley, 1879, nas traças, Scrobipalpuloides absoluta (Meyrick, 1917) e Phthorimaea operculella (Zeller, 1873), em tomateiro. Piracicaba, 1995. 135p. Tese (Doutorado) - Escola Superior de Agricultura "Luiz de Queiroz", Universidade de São Paulo.

RAGURAN, S.; SINGH, R.P. Biological effects of neem (Azadirachta indica) seed on an egg parasitoid, Trichogramma chilonis. Journal of Economic Entomology, v.92, n.6, p.1274-1280, 1999.

RAMIREZ, M.C.; TOSCANO, R.A.; ARNASON, J.; OMAR, S.; CERDA-GARCIAROJAS, C.M.; MATA, R. Structure, conformation and absolute configuration of new antifeedant dolabellanes from Trichilia trifolia. Tetrahedron, v.56, p.5058-5091, 2000. 
RAZURI, V.; VARGAS, E. Biologia y comportamiento de Scrobipalpula absoluta Meyrick (Lep., Gelechiidae) en tomatera. Revista Peruana de Entomologia, v.18, n.1, p.84-89, 1975.

REDDY, G.V.P.; MANJUNATHA, M. Laboratory and field studies on the integrated pest management of Helicoverpa armigera (Hübner) in cotton, based on pheromone trap catch threshold level. Journal of Applied Entomology, v.124, p.213-221, 2000.

ROA, F.G.; JIMENES, V.J. Manejo y produccion de Trichogramma spp. In Colombia. In: SIMPÓSIO DE CONTROLE BIOLÓGICO, 3., Águas de Lindóia, 1992. Anais. Águas de Lindóia: EMBRAPA/CNPDA, 1992. p.138.

RODRÍGUEZ, H.C.; VENDRAMIM, J.D. Toxicidad de extractos acuosos de Meliaceae en Spodoptera frugiperda (Lepidoptera: Noctuidae). Manejo Integrado de Plagas, n. 42, p.14-22, 1996.

RODRÍGUEZ, H.C.; VENDRAMIM, J.D. Avaliação da bioatividade de extratos aquosos de Meliaceae sobre Spodoptera frugiperda (J.E. Smith). Revista de Agricultura, v.72, n.3, p.305-318, 1997.

ROEL, A.R.; VENDRAMIM, R.T.S.; FRIGHETTO, R.T.S.; FRIGHETTO, N. Atividade tóxica de extratos orgânicos de Trichilia pallida (Swartz) (Meliaceae) sobre Spodoptera frugiperda (J.E. Smith). Anais da Sociedade Entomológica do Brasil, v.29, n.4, p.799-808, 2000a.

ROEL, A.R.; VENDRAMIM, R.T.S.; FRIGHETTO, R.T.S.; FRIGHETTO, N. Efeito do extrato acetato de etila de Trichilia pallida (Swartz) (Meliaceae) no desenvolvimento e sobrevivência da lagarta-do-cartucho. Bragantia, v.59, n.1, p.53-58, 2000b. 
ROVESTI, L.; DESEÖ, K.V. Effectiveness of neem seed kernel extract against Leucoptera malifoliella Costa (Lep., Lyonetiidae). Journal of Applied Entomology, v.111, p.231-236, 1991.

SCARDINI, D.M.B.; FERREIRA,L.R.; GALVEAS, P.A.O. Ocorrência da traçado-tomateiro Scrobipalpuloides absoluta (Meyr.) no Estado do Espírito Santo. In: CONGRESSO BRASILEIRO DE ENTOMOLOGIA, 8., Brasília, 1983. Resumos. Brasília: SEB, 1983. p.72.

SCHMUTTERER, $\mathrm{H}$. Potential of azadirachtin-containing pesticides for integrated pest control in developing and industrialized countries. Journal of Insect Physiology, v.34, n.7, p.713-719, 1988.

SCHMUTTERER, H. Properties and potential of natural pesticides from the neem tree, Azadirachta indica. Annual Review of Entomology, v.35, p.271-297, 1990.

SCLAR, C. Neem: mode of action of compounds present in extracts and formulations of Azadirachta indica seeds and their efficacy to pests of ornamental plants and to non-target species. http://www.colostate.edu/ Depts/Entomology/courses/en570/papers_1994/sclar.html. (11 Jan. 2001).

SHIVASHANKAR, T.; ANNADUEAI, R.S.; SRINIVAS, M.; PREETHI, G.; SHARADA, T.B.; PARAMASHIVAPPA, R.; SRINIVASA RAO, A.; PRABHU, K.S.; RAMADOSS, C.S.; VEERESH, G.K.; SUBBA RAO, P.V. Control of coconut black-head caterpillar (Opsina arenosella Walker) by systemic application of 'Soluneem' - A new water-soluble neem insecticide formulation. Current Science, v.78, n.2, p.176-179, 2000. 
SILVA, A.C. da. Efeitos inseticida, deterrente e supressor alimentar de alguns extratos vegetais sobre Ceratitis capitata (Wiedmann, 1824) (Diptera: Tephritidae) e Ascia monuste orseis (Latreille, 1819) (Lepidoptera: Pieridae), em laboratório. Lavras, 1990. 129p. Tese (Mestrado) - Escola Superior de Agricultura de Lavras.

SIMMONDS, M.S.J.; STEVENSON, P.C.; PORTER, E.A.; VEITCH, N.C. Insect antifeedant activity of three tetranortriterpenoids from Trichilia pallida. Journal of Natural Products, v.64, p.1117-1120, 2001.

SOUZA, A.P.; VENDRAMIM, J.D. Atividade ovicida de extratos aquosos de meliáceas sobre a mosca-branca Bemisia tabaci (Gennadius, 1889) biótipo B em tomateiro. Scientia Agricola, v.57, n.3, p.403-406, 2000a.

SOUZA, A.P.; VENDRAMIM, J.D. Efeito de extratos aquosos de meliáceas sobre Bemisia tabaci biótipo B em tomateiro. Bragantia, v.59, n.2, p.173$179,2000 \mathrm{~b}$.

SOUZA, A.P.; VENDRAMIM, J.D. Atividade inseticida de extratos aquosos de meliáceas sobre a mosca branca Bemisia tabaci (Genn.) Biotipo B (Hemiptera: Aleyrodidae). Neotropical Entomology, v.30, n.1, p.133-137, 2001.

SOUZA, J.C. de; REIS, P.R. Traça-do-tomateiro: histórico, reconhecimento, biologia, prejuízos e controle. Belo Horizonte: EPAMIG, 1992. 19p. (EPAMIG. Boletim, 38)

SOUZA, J.C. de; REIS, P.R.; GOMES, J.M.; NACIF, A.P.; SALGADO, L.O. Traça-do-tomateiro, histórico, reconhecimento, biologia, prejuízos e controle. Belo Horizonte: EPAMIG, 1983. 15p. (EPAMIG. Boletim, 2) 
STEIN, U.; PARRELLA, M.P. Seed extract shows promise in leafminer control. California Agriculture, v.4, p.19-20, 1985.

SUNDARAM, K.M.S.; CAMPBELL, R.; SLOANE, L.; STUDENS, J. Uptake, translocation, persistence and fate of azadirachtin in aspen plants (Populus tremuloides Michx.) and effects on pestiferous two-spotted spider mite (Tetranychus urticae Koch). Crop Protection, v.14, n.5, p.415-421, 1995.

TANZUBIL, P.B.; McCAFFERY, A.R. Effects of azadirachtin and aqueous neem seed extracts on survival, growth and development of the African armyworm, Spodoptera exempta. Crop Protection, v.9, p.383-386, 1990.

THOMAZINI, A.P.B.W.; VENDRAMIM, J.D.; LOPES, M.T.R. Extratos aquosos de Trichilia pallida e a traça-do-tomateiro. Scientia Agricola, v.57, n.1, p.13-17, 2000.

TORRECILLAS, S.M.; VENDRAMIM, J.D. Extrato aquoso de ramos de Trichilia pallida e o desenvolvimento de Spodoptera frugiperda. Scientia Agricola, v.58, n.1, p.27-31, 2001.

TRINDADE, R.C.P.; MARQUES, I.M.R.; XAVIER, H.S.; OLIVEIRA, J.V. Extrato metanólico da amêndoa da semente de nim e a mortalidade de ovos e lagartas da traça-do-tomateiro. Scientia Agricola, v.57, n.3, p.407-413, 2000.

VARGAS, $\mathrm{H}$. Observaciones sobre la biologia y enemigos naturales de la polilla del tomate, Gnorimoschema absoluta (Meyrick), (Lep. Gelechiidae). Idesia, v.1, p.75-110, 1970. 
VENDRAMIM, J.D. Plantas inseticidas. In: CONGRESSO BRASILEIRO DE ENTOMOLOGIA, 16., Salvador, 1997. Resumos. Salvador: SEB, 1997. p.10.

VENDRAMIM, J.D.; TORRECILLAS, S.M. Efecto de extractos aquosos de Trichilia pallida (Meliaceae) y genotipos resistentes de maiz sobre Spodoptera frugiperda (J.E. Smith). In: SIMPOSIO INTERNACIONAL SOBRE SUBSTANCIAS VEGETALES Y MINERALES EN EL COMBATE DE PLAGAS, 1., Acapulco, 1998. Memorias. Puebla: Colégio de Postgraduados, 1998. p.133-144.

VERKERK, R.H.J.; NEUGEBAUER, K.R.; ELLIS, P.R.; WRIGHT, D.J. Aphids on cabbage: tritrophic and selective insecticide interactions. Bulletin of Entomological Research, v.88, p.343-349, 1998.

VIANA, P.A.; PRATES, H.T.; CRUZ, I.; WAQUIL, J.M. The effect of aqueous extract of Azadirachta indica leaves on the control of Spodoptera frugiperda fed with corn leaves. In: INTERNATIONAL CONGRESS OF ENTOMOLOGY, 21., Foz do Iguaçu, 2000. Abstract. Foz do Iguaçu: SEB, 2000. p.356.

VILLAS BÔAS, G.L.; FRANÇA, F.H. Utilização do parasitóide Trichogramma pretiosum no controle da traça-do-tomateiro em cultivo protegido de tomate. Horticultura Brasileira, v.14, n.2, p.223-225, 1996.

WEBB, R.; HINEBAUGH, M.A.; RICHARD, K.L.; JACOBSON, M. Evaluation of aqueous solution of neem seed extract against Liriomyza sativae and L. trifolli (Diptera: Agromyzidae). Journal of Economic Entomology, v.76, n.2, p.357-362, 1983. 
WHEELER, D.A.; ISMAN, M.B. Antifeedant and toxic activity of Trichilia americana extract against the larvae of Spodoptera litura. Entomologia Experimentalis et Applicata, v. 98, p.9-16, 2001.

XIE, Y.S.; ISMAN, M.B.; GUNNING, P.; MACKINNON, S.; ARNASON, J.T.; TAYLOR, D.R.; SÁNCHEZ, P.; HASBUN, C.; TOWERS, G.H.N. Biological activity of extracts of Trichilia species and the limonoid hirtin against lepidoptera larvae. Biochemical Systematics and Ecology, v.22, n.2, p.129-136, 1994. 